CHAPTER TWO

\title{
THE GODS DIVINE JUSTICE OR DIVINE ARBITRARINESS?
}

When the poet represents men with contrasting characters he is often obliged to contradict himself, and he doesn't know which of the two opposing speeches contains the truth.

Plato Leg. 4.719c

The person seeking a logical explanation in every case destroys the sense of wonder in everything. For when the logical explanation of something escapes us, that is when uncertainty begins, and thus philosophy.

Plutarch Quaestiones convivales

5.7.1 (680C)

\section{INTRODUCTION $^{1}$}

\section{Controversial diction in archaic poetry}

For now it is a race of iron; and people of that race will never cease from toil and misery by day or night, in constant distress, and the

1 This chapter has a long prehistory. It grew out of a series of lectures for my Leiden students in the eighties of the last century, which formed the basis for a paper I gave at the Bristol symposium "From Myth to Logos?" of 1996, published by Richard Buxton as From Myth to Reason? Studies in the Development of Greek Thought (Oxford 1999). I reserved my own paper for my Sather Lectures, retaining the central argument and the discussion of the Herodotean and Solonic texts largely as they were at the time. At Bristol my paper was duly torn to pieces by the philologists, literary critics and structuralists who constituted an absolute majority among the attendant Hellenists, and as such a particularly inauspicious blend under the circumstances, as the reader of the present chapter will soon understand. Comfort, however, was forthcoming from the warm sympathy for my argument expressed (after the session and the ensuing discussion) by John Gould, whose works on relevant Herodotean issues I had lauded, and Christopher Rowe, whose very relevant article on Hesiod (Rowe 1983) had escaped me. And from Thomas Harrison, who told me that he had just finished an article and was writing a dissertation on the same and related themes in Herodotus, and who sent me both the article (Harrison 1997) and his book (Harrison 2000). The latter comprises a lengthy and exemplary synopsis of the encounter between Solon and Croesus (pp. 33-44) and Polykrates (45-47), written independently but very much like mine albeit with a considerably greater amount of detail and elegance. Since my own argument, 


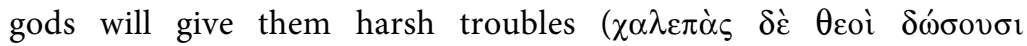

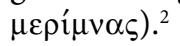

This impression of the condition humaine in the fifth age of the world, the era of its author according to his own definition, represents the pessimistic perception of Hesiod Op. $176 \mathrm{ff}$. (late 8th c.). Comparably, in $O p .100 \mathrm{ff}$. the dire consequences of Pandora's opening of the jar in accordance with Zeus' vindictive design, are pictured as follows: ${ }^{3}$

Sicknesses visit men by day, and others by night, uninvited, bringing ill to mortals, silently (....). Thus there is no way to evade the purpose of Zeus.

Other poets of the archaic period, from the 8th into the 5th c., endorse this pessimistic view in a varicolored palette of words and tones. "There is no man whom Zeus does not give a multitude of ills," sighs Mimnermos (circa 600 BC) fr. 2, in the finale of a poem that opens with praises of "our youth's bloom" but quickly switches over to a list of all the sufferings that old age brings. ${ }^{4}$ In the same vein, the Homeric Hymn to Apollo (7th c.) 189-193 describes how:

the Muses hymn the unending gifts the gods enjoy and the sufferings of men, all that they endure at the hands of the deathless gods, and how they live witless and helpless and cannot find healing for death or defence against old age.

which leans on texts of Homer, archaic Lyric poetry, Herodotus and Solon's Hymn to the Muses, cannot do without any of them, I have decided to maintain this chapter roughly as it was in 1996, though considerably revised and very much expanded inter alia with references to the works of the kindred souls just mentioned.

${ }^{2}$ Unless indicated otherwise all Greek texts and translations are those of West's editions of Hesiod and the Lyric poets: M.L. West, Hesiod. Theogony (Oxford 1966); Hesiod. Works and Days (Oxford 1978); Iambi et Elegi Graeci I (Oxford 1989²), II (Oxford $1992^{2}$ ); Hesiod. Theogony and Works and Days. A New Translation (Oxford 1988); Greek Lyric Poetry. A New Translation (Oxford 1994).

3 The two mythical excursions (i.e. the myth of the five ages or races and that of Pandora) offer "an overlapping, quite complex and ultimately rather subtle picture of the Fall of Man from a condition of divine privilege and sodality to his present one of misery, disease, family trouble and old age" (G. Kirk, The Nature of Greek Myths [Harmondsworth 1974] 142). Doubts on the Hesiodic authenticity in: I. Musäus, Der Pandoramythos bei Hesiod und seine Rezeption bis Erasmus von Rotterdam (Göttingen 2004).

${ }^{4}$ See: M. Griffith, Man and the Leaves. A Study of Mimnermus fr. 2, CSCA 8 (1975) $73-80$. 
Various poems of this period open with a reference to the arbitrariness of the reign of Zeus or the gods as for instance a poetic letter to a young friend by Semonides (circa 600 BC) fr. 1: "Loud-thundering Zeus controls the outcome, lad, in everything, and makes it how he wants." After a long list of all kinds of disillusions and disasters which men, living by the day (ephemerioi), ${ }^{5}$ suffer in their lifetime, he thus summarizes the results of Zeus' interventions: "So we are spared no ill, but numberless dangers and hurts for which we cannot plan exist for mortals." In a more implicit fashion Simonides (late 6th-early 5th c.) 527 says: "There is no ill that men should not expect; in a short space

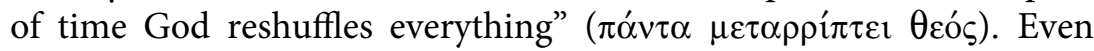
though, apparently, the gods are capable of 'reshuffling' the human situation in bonam or in malam partem, the emphasis is on the shift from good to bad fortune, as it is, for instance, in Archilochos (7th c.) fr. 130. Here, too, in the end it is only the negative pole of divine arbitrariness that receives specification: ${ }^{6}$

It all depends upon the gods. ${ }^{7}$ Often enough, when men are prostrate on the ground with woe, they set them up again;

and often enough, when men are standing proud and all seems bright, they tip them over on their backs, and then they're in a plighta man goes wandering, short of bread, out of his mind with fright.

"As flies to wanton boys, are we to gods; they kill us for their sport": the famed Shakespearian lines seem to mirror this side of archaic Greek view of life. Misery, illness, troubles, they are all gifts of the gods and of Zeus in particular, whose motives are inscrutable and seem to be arbitrary. The unpredictability of the supreme god did not fail to provoke feelings of bewilderment and indignation in authors of the archaic period. They culminate in a few famous, near-biblical ${ }^{8}$ complaints

${ }^{5}$ On the semantics of this term also in other poets of this time: H. Fränkel, Man's 'Ephemeros' Nature according to Pindar and Others, TAPhA 77 (1946) 131-145, translated as 'ЕФНМЕРО $\Sigma$ als Kennwort für die menschliche Natur', in idem 1955, 23-39. Cf. idem 1973, 133 ff.; 530, Index A, 5.5-1. A critical view: M.W. Dickie, On the Meaning of ephêmeros, ICS 1 (1975) 7-14.

${ }^{6}$ As is rightly emphasized by H.-P. Müller, Psalmen und frühgriechische Lyrik. Drei Beispiele, BZ 47 (2003) 23-42, espec. 36-39, who compares it with Psalm 113, whose social motivation, however, provides a more hopeful perspective.

7 The text here is corrupt, but there can be no doubt about the general tenor. I follow West's translation. Cf. West 1974, $131 \mathrm{f}$.

8 The resemblance with certain psalms and other near Eastern texts has been widely acknowledged. See: West 1997, $515 \mathrm{ff}$. The so-called Theodicy, a Babylonian text of c. 1000 BC. (W.G. Lambert, Babylonian Wisdom Literature [Oxford 1975] 63-91) 
about the enigmatic ways of Zeus' justice by Theognis (second half 6 th c. $)^{9} 373-382$, sometimes referred to as 'prayers of contestation': ${ }^{10}$

Dear Zeus, I 'm quite surprised at you. You're king of all, the power and the glory's yours alone; you understand the heart and mind of every man, and yours, Lord, is the highest majesty. So how, Zeus, can you bring yourself to treat alike wrongdoers and the law-abiding man, whether we are disposed to sensible restraint or give way to unrighteousness and crime?

Are there no guidelines set by heaven for mortal men, no path to follow that will please the gods?

Elsewhere, in a closely similar protest against the inconsistencies in the divine treatment of virtuous and evil mortals (743-746), being part of an argument against the belief that descendants will pay for the errors of their ancestors, ${ }^{11}$ the poet complains:

bristles with closely similar expressions, e.g. "Those who neglect the god go the way of prosperity, while those who pray to the goddess are impoverished and dispossessed." See e.g. K.l. Seybold \& J. von Ungern Sternberg, Amos und Hesiod. Aspekte eines Vergleichs, in: K. Raaflaub (ed.), Anfänge politischen Denkens in der Antike. Die nahöstlichen Kulturen und die Griechen (Munich 1993) 115-139, who, in this respect, speak of "die ostmediterrane Koine des 8. Jahrhunderts v. Chr."

${ }_{9}$ By Theognis I mean the corpus of Theognidea. I cannot go into questions of authenticity or chronology here, but I am happy to rely on the expert judgment of M.L. West in $O C D$ s.v.: "The collection may be taken as a representative cross-section of the elegiac poetry circulating in social settings between the late 7 th and early 5 th cent. and it is our best source for the ordinary man's ideas about life, friendship, fate, death and other matters." For the function of the name Theognis as a 'seal': A.L. Ford, The Seal of Theognis: The Politics of Authorship in Archaic Greece, in: T.H.J. Figueira \& G. Nagy (edd.), Theognis of Megara: Poetry and the Polis (Baltimore 1985) 82-95. On the collection: F. Ferrari, Sulla ricezione dell'elegia arcaica nella silloge teognidea. Il problema delle varianti, Maia 39 (1987) 177-197; H. Friis Johansen, A Poem by Theognis 3. The Collection of the Corpus, CeM 47 (1996) 9-23; E.L. Bowie, The Theognidea: A Step towards a Collection of Fragments?, in: G.W. Most (ed.), Collecting Fragments-Fragmenta Sammeln (Göttingen 1997) 53-66. Cf., most recently, the very thorough study by $\mathrm{H}$. Selle, Theognis und die Theognidea (Berlin-New York 2008). Scholars generally agree that the prayers of protest quoted in my text belong to the ipsissima verba of the poet.

${ }_{10}$ J. Labarbe, La prière 'contestataire' dans la poésie grecque, in: H. Limet \& J. Ries (edd.), L'expérience de la prière dans les grandes religions. Actes du colloque de Louvain-la Neuve 1978 (Louvain-la Neuve 1980) 137-148; A. Garzya, La divinité et l'homme chez Théognis, REG 102 (1989) 284-294, espec. 291 f.; Pulleyn 1997, 196-203.

11 Sewell-Rutter 2007, albeit with a focus on tragedy, has much to say about the concept of inherited guilt in general. Cf. Parker 1997, $153 \mathrm{f}$. on the contrast between tragedy and oratory in their appreciation of this theme; Pownall 1998 shows how Xenophon distances himself from the 'sins of the fathers motif'. The same idea 
Again, how is it fair, lord of the deathless gods, that someone who keeps out of wrongfulness, guilty of no transgression and no perjury, a righteous man, suffers unrighteously?

All this is only a very small selection of the utterances that have prompted the label 'archaic pessimism' for the mentality that manifests itself in the Greek literature of this early period.

However, there is another side. In the same work from which we quoted a pessimistic passage, Hesiod never stops reminding us that (Op. 238 f. and 280-283):

Those who occupy themselves with violence (ïßpıs) and wickedness and

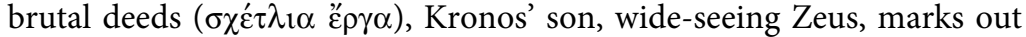
retribution ( $\left.\delta^{\prime} \kappa \eta v\right)$. For if a man is willing to say what he knows to be just, to him wide-seeing Zeus gives prosperity; but whoever deliberately lies in his sworn testimony, therein, by injuring Right, he is blighted past healing.

These two assertions are part of an extended argument replete with warnings against moral misconduct and its consequences, with special reference to the misconduct of the author's wicked brother Perses and the crooked judgments of 'gift-eating kings'. The numerous references to dike and divine retribution in this long section of the Erga ${ }^{12}$ culmi- $^{-}$ nate in the passages just cited in which the divine justice of all-seeing Zeus is celebrated. ${ }^{13}$

And again other poets agree. In his version of the fable of the eagle and the vixen, Archilochos fr. 177, relates how the fox, treacherously

(including the aversion it provoked) prevailed in Israel. See: J.P. Brown, Israel and Hellas (ZAW Beihefte 231, Berlin-New York 1995) $310 \mathrm{f}$.

${ }^{12}$ See: H. Erbse, Die Funktion des Rechtsgedankens in Hesiods 'Erga', Hermes 121 (1993) 12-28. E.F. Beal, Hesiod's Treatise on Justice: Works and Days 109-380, CJ 101 (2005/6) 161-182, argues that the middle portion of Hesiod's poem is a coherent essay on the concept of dike. Generally on Hesiod and justice: M. Gagarin, The Poetry of Justice: Hesiod and the Origins of Greek Law, Ramus 21 (1992) 61-78. J.-U. Schmidt, Die Aufrichtung des Zeusherrschaft als Modell-Überlegungen zur Theogonie des Hesiod I, WJ 14 (1988) 39-70; II WJ 15 (1989) 17-38, sketches the Theogony as a gradual evolution from the brutal and violent regime of Kronos to the development of a regime of order and justice under king Zeus, as does J. Strauss Clay, Hesiod's Cosmos (Cambridge 2003).

${ }_{13}$ West ad loc. (267) gives the necessary information. This justice of Zeus, incidentally, may follow strange paths. In the lines following v. 239 (above) we are informed that the retribution for the violations of one culprit often strikes his whole community with famine, plague and miscarriages. The army may be destroyed, the ships may go down. This brings to mind the theme of suffering as a ransom for the crimes of an ancestor, as we saw in Theognis and as we shall see later in this chapter. 
bereft of his progeny by his trusted neighbour the eagle, invokes Zeus with the prayer to avenge him (successfully, if we may surmise that the lacking end of the story concurs with the fable as we have it in Aesopos): ${ }^{14}$

O Father Zeus, thine is the power in heaven, and thou dost oversee men's deeds, the wicked and the lawful; all creatures' rights and wrongs are thy concern. ${ }^{15}$

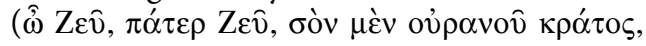

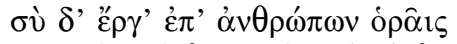

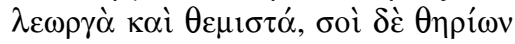

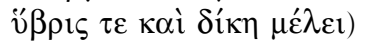

Compare Thgn. $143 \mathrm{f}$. (one out of many in the corpus):

No man has ever cheated guest or suppliant, Cyrnus, without the immortals taking note.

Here, then, we see no desperate-protesting or resigned-surrender to a concept of arbitrary and capricious divine action, but clear tokens of a belief that divine action, however opaque its mechanisms, in the last resort is steered by principles of justice and retribution. An optimistic stance as opposed to the pessimistic one with which this chapter opened.

Corollary to this conception is the idea that man ought not to blame the gods for his own misfortune. The human inclination to attribute one's own misfortune to the will of the gods or of Zeus and thus disclaim guilt, though not necessarily accountability, being ubiquitous in Homer ${ }^{16}$ is censured in the famous 'first attempt at a theodicy ${ }^{17}$ by Zeus himself, right in the beginning of the Odyssey 1.32-34:

\footnotetext{
14 West 1974, 133; idem, Archilochus' Fox and Eagle: More Echoes in Later Poetry, ZPE 45 (1982) 30 ff., with earlier literature.

${ }^{15}$ On the remarkable parallels of this poem in Near Eastern literature see: West 1997, 504 ff. Likewise in fr. 197 Archilochos addresses Zeus as the protector of dike with a complaint about the misbehaviour of Lykambes.

${ }^{16}$ See the evidence in: A. Heubeck e.a., A Commentary on Homer's Odyssey I (Oxford 1988) ad loc. p. 77, and below pp. 164-171.

17 W. Nestle, Vom Mythos zum Logos (Stuttgart $1975=1941) 24$, called this the "älteste Versuch einer Theodizee." So already: W. Jaeger, Paideia. Die Formung der griechischen Menschen (Berlin - Leipzig 1934, many reprints) 86: "Diese Theodizee schwebt über dem ganzen Gedicht." Cf. W. Jaeger, Solons Eunomie, Sitz. Ber. phil.-hist. Kl. Berlin (1926) = Scripta Minora (Rome 1960) 315-337. Cf. Dodds 1951, 32; LloydJones 1983, 28-36; M. Stahl, Solon F. 3D. Die Geburtsstunde des demokratischen Gedankens, Gymnasium 99 (1992) 385-408. S. Lanzi, Theos Anaitios. Storia della
} 
It is astonishing how ready mortals are to blame the gods. It is from us they say that evils come. But they themselves, by their reckless stupidity, have sufferings beyond their fated share.

And it returns in the Theognidean corpus e.g. 833-836:

It's all gone to the dogs, to ruin, and we can't blame any of the immortal blessed gods, Cyrnus. It's human violence, craft, and insolence (ïßprs) that have cast us from success to misery.

In a more philosophic vein, we find the same in the pre-socratic philosopher Demokritos (D-K, B 175):

The gods give to humans all good things, in olden days as well as now. But not the bad and harmful and useless things; these are not given by the gods, but men call them down upon themselves due to their blindness and want of sense. ${ }^{18}$

Both optimistic and pessimistic viewpoints share one more general idea concerning divine power. In contradistinction to more ambivalent assessments of the capacities of individual gods (as we shall discuss in Ch. V), the omnipotence of 'the gods' or 'Zeus' is not subject to doubt or debate in archaic literature. References to the gods' absolute power abound, characteristically often phrased as their arbitrary capacity to act according to their whims, freely and in contrary ways. We have seen one exemplary formulation of arbitrary omnipotence in the fragment of Archilochos fr. 130 quoted above. It strongly resembles the well-known aretalogy on Zeus that opens Hesiod's Erga, which we shall discuss at the end of this chapter, a hymnic prayer that opens with six lines evoking arbitrary omnipotence and proceeds with an appeal to the god's capacity to do justice. ${ }^{19}$ Brief, often proverbial, assertions of divine arbitrary omnipotence abound:

teodicea da Omero ad Agostino (Rome 2000) 39-42, treats the concept of 'theodicy' throughout antiquity, with pp. 37-63 on the archaic Greek period.

${ }_{18}$ In Ch. V p. 397. we will come across a strikingly similar attempt in Stoic theology to tackle the problem of theodicy that is already intimated here.

${ }_{19}$ Strong similarity also in Pind. Pyth. 2.49-52, most probably an intertextual reference to Archilochos, who is the explicit target in the lines immediately following. See: Ch. G. Brown, Pindar on Archilochos and the Gluttony of Blame (Pyth. 2.52-56), JHS 126 (2006) 36-46. 
Hom. Od. 16.211 f.:

Easy is it for the gods, who live in heaven, either to bestow honour on

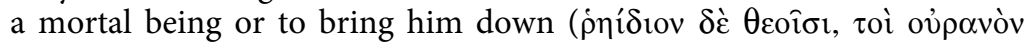

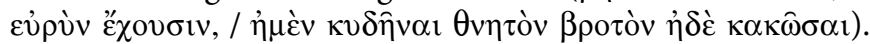

Hom. Od. 6.188 f.

Olympian Zeus himself dispends happiness to men, both good and

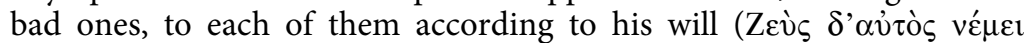

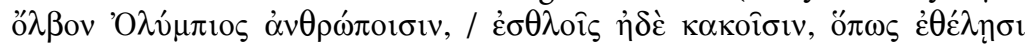
$\dot{\varepsilon} \kappa \alpha ́ \sigma \tau \omega)$.

Thgn. 157 f.:

Zeus tilts the balance now to this side, now to that: now to be rich, now to be penniless.

Pind. Isthm. 5.52:

Zeus dispenses this and dispenses that, Zeus who is Master of all (Zev̀ $\varsigma$

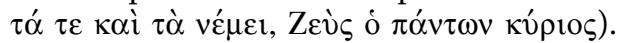

The idea is as old as Hom. Il. $24.527 \mathrm{ff} .{ }^{20}$ the famous image of the two jars (pithoi) of Zeus, one with good, the other with evil things, from which he assigns the mortals either mixed, or solely evil things. Here, as in some examples above, his arbitrary regime verges towards the negative.

The mortal's only refuge in this situation of amêchaniê (helplessness, resourcelessness), as Semonides calls it, ${ }^{21}$ lies in endurance, which often manifests itself as the comforting insight that every mortal gets his turn in misfortune. Therefore the human sufferer is advised to comply with this rhythmos. ${ }^{22}$ If, then, we do discern a global agree-

${ }^{20}$ But how old is that? Both conceptually and linguistically the passage is quite untypical of Homer. See: Richardson, comm. ad loc. On good and ill fortune as gifts of the gods: Fränkel 1973, 534, Index A. 5.8-3.

${ }^{21}$ On the notion: Dodds 1951, $29 \mathrm{f}$. On the wide range of de/connotations of this term in various authors see: R.P. Martin, Healing, Sacrifice, and Battle: Amechania and Related Concepts in Early Greek Poetry (Innsbruck 1983); G.F. Held, Archilochos' 'A $\mu \alpha \chi \alpha v i \alpha$. Pindar Pythian 2.52-56 and Isthmian 4. 1-3, Eranos 101 (2003) 30-48. On the connection between amêchania and agnosia (lack of knowledge/insight) in archaic literature: S. Foellinger, Die Funktion von Nicht-Wissen in der frühgriechischen Literatur, in: J. Althoff (ed.), Philosophie und Dichtung im antiken Griechenland. Akten der 7. Tagung der Karl und Gertrud Abel-Stiftung 2002 (Stuttgart 2007) 53-65.

${ }^{22}$ This notion, coming close to " $E$ 'n la sua volontade è nostra pace" (Dante, Paradiso III, 85), glimmers through in Archil. fr. 13, 5 ff.: "But then, my friends, the gods for ills past healing have set endurance $(\tau \lambda \eta \mu о \sigma v ́ v \eta)$ as the antidote. This woe is dif-

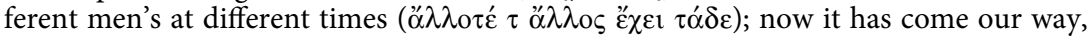
and we bemoan our bleeding wound; another day 't will pass to others. Come then, 
ment on commendable forms of human reaction to misfortune, there is, as we just saw, no consensus whatsoever with regard to the possible grounds for the gods' (negative) interventions. Are they inspired by arbitrary and capricious impulses as we may summarize it once more in the words of Thgn. $133 \mathrm{ff}$.

No one's responsible for his own gain or loss; it is the gods that give us both. (....) We mortals have no knowledge, only vain belief; the gods fix everything according to their will.

Or is divine interference in the end inspired by principles of justice and retribution as Hesiod keeps hoping, as in Op. 706. "Beware the punishment of the immortal blessed ones"?

Not only do we find the two contrasting options dispersed throughout the literary testimonies of the archaic period, we also detect them in the works of (or ascribed to) one and the same author. ${ }^{23}$ As far as our evidence allows us to judge, no archaic author displays a coherent and consistent monolithic worldview in his way of coping with the stupendous and enigmatic events in human life. ${ }^{24}$ The corresponding

everyone endure $(\ldots \ldots \ldots)$ spend no more time in womanish lament." They are common in archaic poetry. For 'endurance' e.g. Thgn. 591: "One must endure whatever

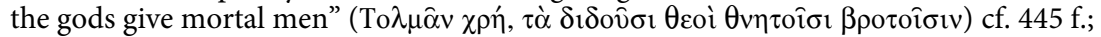
$555 \mathrm{f}$.; H. Dem. 147 f.: "What the gods send us $(\theta \varepsilon \hat{\omega} v \delta \hat{\omega} \rho \alpha)$ we mortals bear perforce,

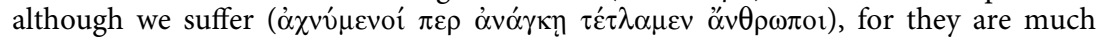
stronger than we." Cf. 216 f.; Pind. Pyth. 3.82. On the notion: Fränkel 1973, 87 f.; 530, Index A 5.5-2. For the 'allote allos' idea see: Krause 1976. The term rhusmos seems to be an Archilochean invention, as in fr. 128, 5-7: "In your rejoicing let your joy, in hardship your despairs be tempered: understand the rhusmos shaping men's affairs

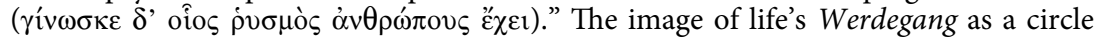

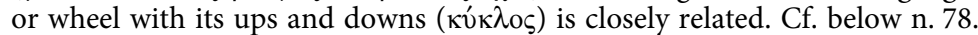

${ }^{23}$ That one must always allow for differences in context will be the main thesis of the present chapter as it is of the whole book. A recommendable exercise is to peruse Hom. Od. 14, a book that bristles with references to Zeus (both in personal and in generic form), the gods, some god, god, as well as all the gods and an individual god (ll. 39, 53, 57, 61 f., 65, 74, 82 f., 119, 150, 175, 183, 198, 227, 235, 242, 246, 268, 300, $309,348,357,366,391$, plus the sacrificial scene, on which see: Ch. IV pp. 367-370), and try to determine their specific functions in their various contexts and discourses. It is also true that there are individual differences in emphasis, expression and imagery typical of different archaic authors, one rather stressing the element of the divine retribution, another underlining the arbitrariness of fate.

${ }^{24}$ See for an instructive survey of the very divergent explanations of disaster and the moral aspects of just recompensation: K. Alt, Die Dichter und das Böse, in:

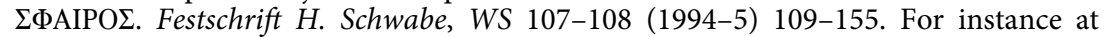
p. 154, concerning attempts to justify the inscrutable ways of the gods: "wo sie (this type of explanation) aber als dominante Interpretation versucht wird, von der Odyssee bis zu Euripides, erweist sie sich als schwierig, in der Regel als nicht Konsequent 
lack of clarity and consistency in the religious views of these authors has left deep marks in the scholarly discussion of the second half of the twentieth century.

\section{Modern Voices}

The issue under discussion, with a focus on the relationship between divine justice and human responsibility, has been the central concern in the Sather lectures of no fewer than three outstanding scholars: Eric Dodds (1951), Hugh Lloyd-Jones (1971) and Bernard Williams (1993). The first two scholars took diametrically opposed positions. Dodds denied the Homeric epic "the tendency to transform the supernatural in general, and Zeus in particular, into an agent of justice," ${ }^{25}$ and traced a gradual development in the 'education of Zeus' with a hesitating beginning in the Odyssey and gradually increasing from Hesiod onwards. In the view of Lloyd-Jones, on the other hand, the justice of Zeus can be fully attested as early as the Iliad: "according to the terms of Zeus' justice (.....) both Agamemnon and Achilleus receive rough justice for their injustice to each other." ${ }^{26}$ Moreover, his book is one unabashed attempt to save Greek divine ethics from the inconsistencies and ambiguities that force themselves on the reader of passages such as those presented in the first section of the present chapter. ${ }^{27}$

durchführbar oder unzulänglich, wenn nicht gar, wie nich selten bei Euripides, als absurd." Cf. also below n. 110 .

${ }_{25}$ Dodds 1951, 31, where one also finds some exceptions, while at p. 32, he finds "no indication in the narrative of the Iliad that Zeus is concerned with justice as such." The sole notorious exception is $16.384 \mathrm{f}$., where Zeus is pictured punishing those "who by violence pronounce in the market-place crooked judgments and drive out justice, having no care for the concern of the gods." This, however, is so unique and dissimilar from any other Iliadic expression that it is often taken as Hesiodic rather than Homeric in character (so also Dodds $52 \mathrm{n}$. 16), sometimes also as a later interpolation. It is perhaps less difficult to agree with this verdict since recent scholarship is reshuffling the chronological relationship between Iliad, Odyssey and Hesiod's work. But at this point I still find it hard to disagree with Janko 1982.

${ }^{26}$ Lloyd-Jones 1971, 21 and 27.

27 In this and other respects he was preceded by Festugière 1952, 26-36, who discussed the same problem and, rather sweepingly, wrote (27): "Since Homer and Hesiod there is an unshakable confidence in the justice of Zeus. God is no longer God if he does not join the attribute of justice to that of omnipotence." I cannot go into the relevant critical reactions on Lloyd-Jones' book and, more especially, on the intimations of special pleading in it. The core problem is that justice is not an unequivocal concept. The most vulnerable point, as many critics have not failed to note, is the solution he proposes. He inter alia defines divine justice as "the divinely appointed order of the universe," an order that is not always, not even usually, open to human scrutiny 
After reading Lloyd-Jones' Justice of Zeus, Dodds generously wrote to its author: "I stressed the element of change in Greek beliefs, you stress the element of continuity; we are both of us right, though both of us

and hence can prevail without its author being just. Despite its precariousness-if not arbitrariness-this is a rationale often resorted to in recent scholarship. For instance by S. Nelson, The Justice of Zeus in Hesiod's Fable of the Hawk and Nightingale, ClJ 92 (1997) 235-247, espec. 247: "Hesiod's Zeus is just, but his power is not dependent upon his justice. Rather it is justice that is dependent upon the invincible power of Zeus." I am not absolutely certain that I understand what this means. Nor do I sympathize with the desperate squirming in search of an intrinsic logic in Hesiod's fable, as for instance by J. Dalfen, Die üßpıs der Nachtigall. Zu den Fabel bei Hesiod (Erga 202-218) und zur griechischen Fabel im allgemeinen, WS 107-108 (1994-1995) 157-177 (= G. Petersmann [ed.], J. Dalfen, Kleine Schriften [Salzburg 2001] 1-18), and in the same year Th.K. Hubbard, Hesiod's Fable of the Hawk and the Nightingale Reconsidered, GRBS 36 (1995) 161-171, both suggesting that the nightingale is the one which has become hybristic by involving with-or challenging-the more powerful and who is rightly punished for that. All this without even the faintest allusion by the author himself. In the same vein and equally sophisticated: W. Allan, Divine Justice and Cosmic Order in early Greek Epic, JHS 126 (2006) 1-35. St. White, Io's World: Intimations of Theodicy in Prometheus Bound, JHS 121 (2001) 107-140, considers "Zeus of this play to be not the harsh and destructive despot imagined by most today, but the benevolent source and ultimate arbiter of justice for both gods and humanity." I am not sure whether Prometheus or Io may have found comfort in this idea. Cf. also Sh.D. Sullivan, Psychological and Ethical Ideas: What Early Greeks Say (Mnemosyne Suppl. 144, Leiden 1995) Ch. V. 'Justice'. Recently, Lloyd-Jones rejoined the debate, in 'Zeus, Prometheus, and Greek Ethics', HSCPh 101 (2003) 49-72: a new defence of both $P V$ 's authenticity and its general, albeit specifically early Greek, idea of divine justice. D. Cohen, The Theodicy of Aeschylus: Justice and Tyranny in the Oresteia, GeR 33 (1986) 129-141 (also in: I. McAuslan \& P. Walcot (edd.), Greek Tragedy [Oxford 1993]) espec. 139, summarizes this type of rescue attempt: "Thus the justice of Zeus does prevail, but it is the arbitrary justice of the right of the stronger: persuasion and compulsion, backed by fear and force," and rejects them (ibid. 140 n. 11): "The problem is that few scholars like to face the intractability of the problem of evil; they would rather explain it away and believe that justice triumphs, that divinity is ultimately benevolent. As Kant has showed with devastating finality, however, in his Über das Misslingen aller Philosophische Versuche in der Theodicee (1791) no such comfort is rationally possible. This is, I am convinced, precisely the way in which Aeschylus wished to present the problem of innocent suffering, and easy explanations should not be sought to defuse the force of his argument." Yamagata 1994, Part I, has an insightful discussion of exactly this amphiboly in archaic Greek culture: the gods distribute good and bad fortune to man not in response to their moral behaviour, but as required by fate, and therefore do not function as the guardians of justice in the human world. Men, however, cannot abandon the wishful thinking that the gods are concerned with human morality. However, "our impression is that the god's moral functions do not meet much of human expectation" (p. 21). I agree and cannot help feeling that here we have laid a hand on the moot point in all these theories that defend the justice of Zeus by re-defining it as his care for preserving a 'cosmic order'. One recognizes the very same flaw in the never-ending discussion on divine theodicy among Christian theologians, where excusing references to God's (hidden) plans are to little avail for those who would prefer a god that punishes the evil and recompenses the good. For some illustrations see the end of this chapter. 
at times exaggerate the partial truth we are stressing." While easily matching these great predecessors on the Sather chair in my inclination to exaggerate my own point, and though very much prepared to acknowledge the relevance of both continuity and change in matters of theodicy, I would like to focus my attention on another issue, namely the persistent and pervasive lack of consistency in expressions concerning divine causation of good and evil in archaic and early classical literature. I am referring to the constant wavering between hopeful expectation and desperate resignation, between an optimistic and a pessimistic stance, as exemplified in alternations between the belief in divine justice on the one hand, and in arbitrary fate on the other.

I will argue that, confronted with unaccountable, in particular catastrophic events, (many) Greeks of the archaic period seem to have shared one general feeling more than any other: that there is not one universal and monolithic principle of causation, or if there is, that no single definition would suffice in a world of great complexity. Many texts, from Homer down to the Classical period, serenely juxtapose two pictures of divine causation which-in our eyes-are incompatible: the one of seemingly amoral, arbitrary meddling, the other of moral and just intervention. In the texts which I have in mind, the two visions are not differentiated in terms of sharp boundaries, nor reconciled in an intellectually satisfying coherent system. It is my view that this picture of multiple causality must be rated among the most characteristic and pervasive traits of archaic Greek theological expression. Its recognition necessarily involves a reappraisal of the terms in which the dilemma has been conceived in scholarly discussion so far.

In the course of my argument I shall refer to a number of passages of different authors, Homer to begin with, all of them belonging to the most celebrated of Greek literature and heavily exploited in earlier scholarly discussion. Even so, I feel that a presentation of relevant texts, albeit in the form of an anthology of the most relevant phrases and expressions, is a prerequisite for adequate information, and not only for the profane. On the other hand, it will be impossible to discuss these texts in great philological detail, let alone to venture recklessly far into the arena of modern scholarly debate. 


\section{HOMER}

By way of overture-honoris causa and because it will lead us medias in res-we will tackle Hom. Il. 19.86-96, the notorious passage in which Agamemnon reveals his perception of the causes of his unfortunate behaviour as related in the first book of the Iliad:

Not I am to blame. It was Zeus and Moira and the Erinys who walks in darkness that put wild ate in my mind, that day of the meeting, when on my own authority I confiscated Achilles' prize. What could I do? God (theos) accomplishes everything || Ate, the eldest daughter of Zeus, who blinds us all, the accursed one!

Why, even Zeus was blinded by her once, and he is known to stand above all men and gods......

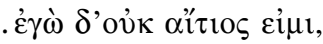

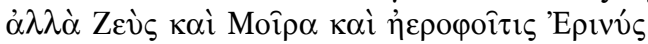

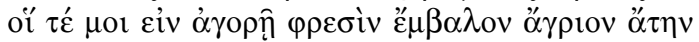

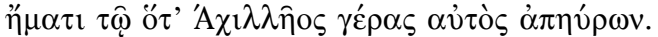

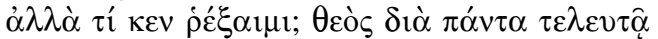

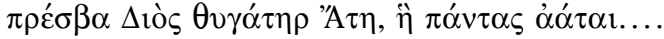

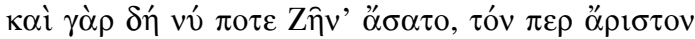

$\dot{\alpha} v \delta \rho \hat{\omega} v \dot{\eta} \delta \grave{\varepsilon} \theta \varepsilon \hat{\omega} v \varphi \alpha \sigma^{\prime} \iota^{\prime \prime} \mu \mu \varepsilon v \alpha$ l.

Then follows an intermezzo relating how Zeus, once deceived by Ate, in his rage seized her and cast her down from the Olympus, swearing that she would never come to the seat of the gods again. Next Agamemnon continues his argument contending that the same had happened to him, ${ }^{28}$ and (136):

I never could forget the Ate who had blinded me that day. But since I was blinded and Zeus robbed me of my wits....

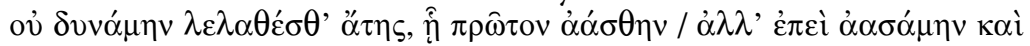

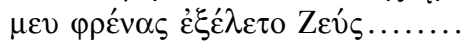

${ }^{28}$ It has often been remarked that with this analogy Agamemnon places himself on the same level as Zeus. The parallels between the two in the present speech have been meticulously elucidated by D. Lohmann, Die Komposition der Reden in der 'Ilias' (Berlin 1970) 77 f. On Agamemnon's excuse see besides Dodds 1951, 1-17, especially: R.J. Rabel, Plot and Point of View in the Iliad (Ann Arbor 1997) 178-186; O. Taplin, Agamemnon's Role in the Iliad, in: C. Pelling (ed.), Characterization and Individuality in Greek Literature (Oxford 1990), espec. 65 and 76. On Zeus' deception by Ate: H. Erbse, Untersuchungen zur Funktion der Götter im homerischen Epos (Berlin 1986) $11-23$ 
Dodds made this episode into the show-piece of the first chapter of his Greeks and the Irrational and others have responded. It was particularly the lavish amount of ate (infatuation, delusion, blind madness) ${ }^{29}$ in a variety of nominal and verbal expressions that stimulated him to broach some seminal questions concerning tensions between human and divine responsibilities. This issue, however central in the works of so many scholars, from Dodds to Willams and from Snell to Padel, ${ }^{30}$ is not my major concern, which, here and henceforth in this chapter,

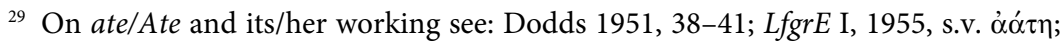
Edwards comm. ad loc. p. 247, with bibliography, and Hainsworth ad Il. 9, 502. Some recent discussions: Padel 1992, 166-177; Yamagata 1994, 50-60; M. Finkelberg, Patterns of Human Error in Homer, JHS 115 (1995) 15-28; Padel 1995, 167-192; 197-202; 249-259; D. Hershkovitz, The Madness of Epic. Reading Insanity from Homer to Statius (Oxford 1998) $128 \mathrm{ff}$. Some paraphrases: "a temporary clouding or bewildering of the normal consciousness" (Dodds); "the spirit that inspires an act of irrational folly (...) one that produces unwelcome consequences" (Hainsworth); "temporary absence of understanding, ascribed to divine intervention" (Padel 1995). In the course of time the meaning developed towards the consequences of the infatuation in terms of erroneous behaviour and its punishment, and further into 'ruin.' NP s.v. Ate: "Die von Göttern gesandte Verwirrung der Sinne-dadurch ausgelöste Fehlhandlung-daraus resultierender Schaden." Dodds 1951, 5 calls Ate at the place under discussion not a personal agent but a "transparent piece of allegory." I am not sure that this is a useful distinction for Homer or archaic poetry in general. Cf. Poetscher 1959. The never ending discussion about personification and/or allegory has been considerable advanced by Borg 2002, 37-81, with Ate at pp. $44 \mathrm{f}$. and 48 . Anyway, in our passage she clearly is personified and thus becomes a personal agent. Though sent by the three divine powers, she takes the initiative and henceforth acts on her own account.

${ }^{30}$ Some interpretations of the phenomenon of 'double motivation': M.P. Nilsson, Götter und Menschen bei Homer, ARW 22 (1923-4) 363-390; G.M. Calhoun, Homer's Gods: Prolegomena, TAPhA 68 (1937) 11-25, espec. 24 f.; G.M.A. Grube, The Gods of Homer, Phoenix 5 (1951) 62-78, espec. 74; A. Lesky, Göttliche und menschliche Motivation im homerischen Epos, Sitz. Ber. Heidelberg Phil.-Hist. Kl. 4 (1961); A. Schmitt, Selbständigkeit und Abhängigkeit menschlichen Handelns bei Homer: Hermeneutische Untersuchungen zur Psychologie Homers (Abh. Akad. Wiss. Mainz. Geist.Sozialwiss. Kl. 1990 no. 5), on Agamemnon's ate especially 85-89; Williams 1993, Ch. 3 'Recognising Responsibility'; H. Erbse, Über Götter und Menschen in der Ilias Homers, Hermes 124 (1996) 1-16. On the same phenomenon in Herodotus: Th. Spath, Das Motiv der doppelten Beleuchtung bei Herodot (Diss. Wien 1968). Cf. also below nn. 52 and 54. On the shift from the attribution of the whole reponsibility to the gods towards the insight that the gods may be only partially co-responsible in Aeschylus, see: E. Fraenkel ad Aesch. Ag. 1. 810, p. 34. The positive side of such a shared responsibility can be found in the proverbial wisdom that in order to persuade the gods into

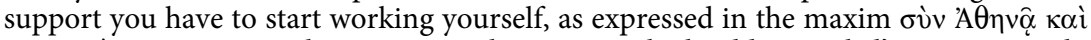
$\chi \varepsilon i ̂ p \alpha$ kíveı. See: Versnel 1981a, 24 with n. 89, to which add: Fraenkel's comm. Aesch. Agamemnon p. 373. Or as the citizens of Constantinople in $626 \mathrm{AD}$ were reminded:

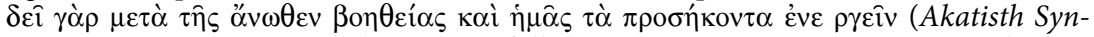
axarium, Migne P.G. 92, col. 1349). A full discussion in J. Jouanna, La main de dieu qui touche. Remarques sur l'emploi d'une maxime, REG 106 (1993) 181-194. Striking parallels from the modern Mediterranean: Banfield 1958, 108 f.; Friedl 1962, 75 f. 
focuses on the more complex problems inherent in a gamut of diverse but concurrent natural, supernatural, and divine forms of causation.

Agamemnon's plea for excuse has grown into a notorious crux interpretum. ${ }^{31}$ My primary concern is the question of how precisely Zeus and Moira and Erinys are supposed to relate and indeed co-operate. For co-operation it is: they are depicted as acting together in putting wild ate in Agamemnon's mind. Theologically, Zeus and Moira do have a family resemblance and are sometimes mentioned together on varying levels of relationship. ${ }^{32}$ However, "Erinys is somewhat surprising here" to quote an understatement by one commentator, ${ }^{33}$ since the customary responsibility of the Erinues in Homer is the execution of curses with regard to violations of the moral and natural order, the persecution of crimes against parents, betrayal of family and the punishment of oath-breakers. ${ }^{34}$

The core of the problem lies in the conjunction of three dissimilar agents: one personal 'mythological' god (Zeus) who in the Iliad generally exercises his supreme power in an arbitrary-at least inscrutableway, betraying some interest in the execution of justice exclusively in punishing perjurers, and those who wrong suppliants and xenoi. ${ }^{35}$ The second actor on this stage began her career as a non-personal principle

${ }^{31}$ Already in antiquity, as various remarks in the scholia testify. See: Davies 1995, who offers a good introduction to the various problems in the text.

32 Also in cult Zeus is sometimes connected with the Fates. As Moiragetes he had a temple in Delphi (Paus. 10.24.4), a cult in Athens $\left(I G \mathrm{I}^{3} 7\right)$ and an altar at Olympia (Paus. 5.15.5). The Moirai received sacrifice together with Zeus Patroos at Halikarnassos (Syll. ${ }^{3}$ 1044.5). Cf. Bowra 1961, 410, and below n. 43.

${ }_{33}$ M.W. Edwards, The Iliad. A Commentary V (Cambridge 1991) ad loc.

${ }^{34}$ A to my mind inadmissible solution is the one by Leaf "that from this passage it appears that they have wider functions." The Erinues (always plural except here and at Od. 15.234) appear seven times in the Iliad and five times in the Odyssey, often as executors of a curse. As avengers of some serious infringement of family codes: Il. 9.454; 9.572; 15.204; perhaps also 21.412, where Hera curses her son Ares for behaving against her will; 15.234 (doubtful); Od. 2.135; 11.280. Brutalizing a xenos: $O d$. 17.474. Atoning for a crime of a father: $O d$. 15.234? False oath: Il. 19.259. Unclear: Il. 19.418, where the Erinyes check the voice of the horse Xanthos when he is predicting the death of Achilleus (thus restoring normal boundaries between man and animal?). And still very unclear our Il. 19.86-91. See on some of the enigmatic testimonia just mentioned: S.I. Johnston, Penelope and the Erinyes: Od. 20, 61-82, Helios 21/2 (1994) 137-159; eadem, Xanthus, Hera and the Erinyes: Il. 19.400-419, TAPhA 122 (1992) 85-98. More recent lit. in NP s.v. Erinys.

${ }_{35}$ On Zeus' 'moral functions' of this type, espec. on Zeus Xenios, Hiketesios, and Horkios see: Yamagata 1994, 4-13. 
representing 'one's portion or share'36 developing into 'that which is destined to be', often translated as 'one's fate'. ${ }^{37}$ She is often pictured as an independent deified personification and so she seems to be here, witness her position in between two personal agents and joining these partners in a common action. ${ }^{38}$ The third is a demonic authority prosecuting and punishing a person guilty of the specific transgressions just mentioned, and thus introducing the element of personal culpability as opposed to the ambivalent rule of the highest god and the arbitrary, but mostly negative, actions of Moira.

The three do not fit smoothly together, an unpleasant situation that prompts interpreters to go in search of connotations that may clarify their presence and co-operation in one passage. As did Dodds, p. 6/7: after defining Zeus as the mythological agent (being the only individual Olympian who is credited with causing ate in the Iliad) and moira as the 'portion' or 'lot' ${ }^{39}$ that befell Agamemnon as the concrete

${ }^{36}$ On the possible origin of moira/moros and related concepts of fate ( $\delta \alpha \dot{\mu} \mu \omega v, v \varepsilon ́ \mu \varepsilon \imath$, $\alpha \hat{⿵} \sigma \eta)$ in the context of distribution of portions of sacrificial meat see fundamentally: G.J. Baudy, Hierarchie oder: Die Verteilung des Fleisches. Eine ethologische Studie über die Tischordnung als Wurzel sozialer Organisation, mit besonderer Berücksichtigung der altgriechischen Gesellschaft, in: B. Gladigow \& H.R. Kippenberg (edd.), Neue Ansätze zur Religionswissenschaft (Munich 1983) 131-174.

${ }^{37}$ There is some truth in the description by R.P. Winnington-Ingram, Studies in Aeschylus (Cambridge 1983) 171, "that moira (in whatever degree of personification, singular or plural) - and indeed the whole wide vocabulary of fatality-connotes the rigid, the intractable, the violent, the blind, the primitive, aspect of divine operation."

${ }^{38}$ Most (but not all) editors grant her a capital here, as of course at other places in Homer. That the Moirai boasted cults in later times (Corinth and Thebes, Paus. 2.4.7 and 9.25.4, respectively) cannot be taken as directly relevant for Homer. More relevant perhaps is the prayer to the Moirai (TGF p. XX) ascribed to Simonides by von Wilamowitz and again with extensive argumentation by Bowra 1961, Appendix II, 'A Prayer to the Fates' (=CQ 8 [1958] 231-240). This prayer draws heavily on Hesiod's equally personalized picture of the Moirai. See below p. 233. On Dodds' view see next note.

${ }^{39} \mathrm{He}$ argues at p. 7, that "Moira is not yet a personal goddess who dictates Zeus or Cosmic Destiny like the Hellenistic Heimarmene." Rather "by treating his 'portion' as an agent-by making it do something-Agamemnon is taking a first step towards personification." Though both statements may be correct in themselves, as arguments they fail to justify his translation " $m y$ portion" and the concomitant refusal to write moira with a capital. The problem here is whether author and audience clearly differentiated between the two visions. See above n. 29. The next dilemma, then, concerns the choice between two further options: Nilsson GGR I, 364: Moira as a personification here comes into being "unter unseren Augen," or W. Poetscher, Moira, Themis und $\tau$ un im homerischen Denken, WS 73 (1960) 5-39, espec. 24, who argues that right from the beginning both aspects, the abstract and the person, were inseparably present in the concept of Moira. Aesch. $P V .511$ provides a splendid instance of how moira (the thing) and Moira (the divine agent) are conflated in one expression:

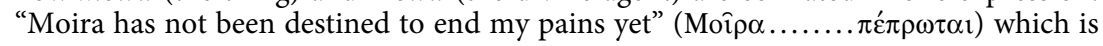


effect of Zeus' decision, he suggested that "Erinys, then, could be the immediate agent who "ensures the fulfillment of a moira." He thus made an attempt to mould the so far enigmatic parataxis of three disparate agents into an-in our view more manageable-hypotactic relationship. However, the closely comparable exculpating formula of the horse Xanthos in Il. 19.409 f.: "not we are to blame, but the great god

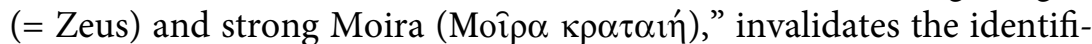
cation of moira = portion. The epithet argues in favour of the personal nature of Moira side by side with Zeus. As to Erinys, the cautious wording of the last part of his suggestion betrays Dodds' own doubts. With good reason, for in Homer it is not the Furies' regular job to take care of the fulfilment of a moira. On the other hand, their specific retributive responsibilities in no way tally with any act of Agamemnon the poet had deigned to inform the reader/listener about. Last but not least, her juxtaposition with either one of the two other agents in the present context is unique in Homer. ${ }^{40}$

What we detect in Dodds' (and not only in his) interpretation is an example of a typically modern drive towards transparency and explicitness, a desire to bring to light a coherence that Homer left implicit and opaque. ${ }^{41}$ Such assumptions naturally raise the question whether Homer indeed did have a 'theory' or even as much as a vague

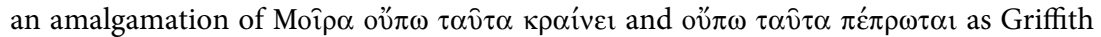
1983, comm. a.l. shows, concluding on moira: "the status of this word is impossible to define with precision." Just so in Homer. See also Fraenkel, ad Aesch. Agam. 1535 f., and $\pi \varepsilon \pi \rho \omega \mu \varepsilon ́ v \eta \mu$ îि $\alpha$ in Herodotus (below p. 185). Cf. also below n. 42.

40 In cult (few) connections between Moirai and Erinyes do occur. See Bowra 1961, 412; Wüst RE Suppl. 8, 86-91. In Aesch. PV 516 the Erinyes are united with the Moirai, but their relationship is far from clear and certainly not unequivocal. See the commentaries of Groeneboom and Griffith 1983, ad loc. and below n. 44. On Zeus, Moira, and the Erinyes in Aeschylos see: P.W. Winnington-Ingram, o.c. (above n. 37), 154-174, espec. $170 \mathrm{ff}$. On the (changing) nature of the Erinyes in the Oresteia: A.L. Brown, The Erinys in the Oresteia: Real Life, the Supernatural, and the Stage, JHS 103 (1983) 13-34. Recently: Parker 2009, 148-153.

${ }^{41}$ Throughout the present chapter there will be warnings against the dangers of overinterpretation (on the term see below n. 105) and in particular of modern readers' drive to rashly assume connections, underlying meanings and author's intentions in their texts, sometimes explicitly appealing to the author's intentional silence. For Homer one might by way of example mention R. Janko, The Iliad: A Commentary vol. 4 (Cambridge 1992) ad 16.384-393: "The poet comes near to an open justification of Troy's fall, all the more persuasive because we are left to infer it for ourselves" (my italics). Many of the desperate attempts to detect 'justice' in Zeus' acts in the Iliad resort to such $e$ silentio arguments. See for a caustic, but correct, criticism of this type of creative reading of Homer: A.M. van Erp Taalman Kip, The Gods of the Iliad and the Fate of Troy, Mnemosyne 53 (2000) 385-402, espec. 395-399. On 
notion about the coherence of the three agents and their functions. And corollary to this a second question prompts itself: did he need to have one? The many studies on Moira ${ }^{42}$ and the ways in which Zeus and Moira (or Aisa) are supposed to cohere or interact in epic, and a fortiori the variety of different, often conflicting, upshots of these studies justify these questions. They certainly do nothing to weaken the conclusions drawn, long ago, by scholars such as Eitrem, Nilsson, Poetscher and Burkert, that the workings of Fate (Moira, Aisa) and those of 'the god(s)' or Zeus, are essentially separate, independent, often inextricable, but freely co-existent conceptions. ${ }^{43}$ As they continue to be in later Greek literature, as we will see. ${ }^{44}$

assumedly deliberate devices of paralipsis or implicitness in later archaic lyric poetry (espec. Pindar) and Herodotus, see below pp. 192-194.

${ }_{42}$ Eitrem, art. Moira, RE 1932, 2449-2497; W. Krause, Die Ausdrücke für das Schicksal bei Homer, Glotta 25 (1936) 143-152; idem, Zeus und Moira in Homer, WS 64 (1949) 10-52; U. Bianchi, $\triangle I O \Sigma$ AIIA. Destino, uomini e divinità nell'epos, nelle teogonie e nel culto dei Greci (Rome 1953); Chantraine 1954, 69-73; B.C. Dietrich, Death, Fate, and the Gods. The Development of a Religious Idea in Greek Popular Belief and in Homer (London 1965); J.V. Morrison, Kerostasia, the Dictates of Fate, and the Will of Zeus in the Iliad, Arethusa 30 (1997) 273-307 (arguing for a tension deliberately created by 'the author' between predetermination by Fate and freedom of decision) with further literature. Yamagata 1994, 105-120 has a good discussion of the different scholarly positions with an attractive conclusion. See also the good summary of the Stand der Forschung in: A. Henrichs, art. Moira in: NP 8 (2000). On personified Moirai see: S. De Angelis, LIMC VI 1 (1992) 636-648.

${ }^{43}$ Eitrem 1932, 2453 (with earlier literature at 2459): "Beide Auffassungen (viz. Moira as superior or inferior to the god[s]) behaupten sich ruhig nebeneinander, eine harmonisierende homerische Dogmatik durchzuführen ist aussichtlos;" Nilsson GGR I, 364: "Die Vorstellung von Schicksal und diejenige der Götter und ihre Macht (sind) zwei voneinander unabhängige und frei nebeneinander herlaufenden Auffasungen des Lebens;" Poetscher o.c. (preceding note) 24: "eine Lösung im Sinne einer Über- oder Unterordnung erweist sich als unmöglich," and cf. idem in NP s.v. Moira col. 1394; Burkert 1985, 129, on the relation between Zeus and Moira: "For causal thinking an insoluble problem results from the opposition between fateful predetermination and divine freedom. For the Iliad this is not a problem but a conflict which must be fought out, just as the whole of life is marked by conflicts." Cf. Chantraine 1957, 69-73; Lloyd-Jones 1971, 4 f. with n. 19. Griffith 1983, 18: "In Homer, the relationship

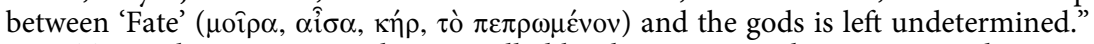
Even Tsagarakis 1977, 129, who generally likes his Homeric characters straight, must admit: "Zeus' relation to moira is not quite clear."

${ }^{44}$ The shifts and inversions in the relative positions attributed to Zeus and Moira or Moirai, in the oeuvre, sometimes even in one work, of one author, are a striking case in point and may bewilder the modern reader. Extremes in Homer are for instance Dios aisa and kerostasia on the one hand and Od. $3.236 \mathrm{ff}$. on the other. Most typically we also find the amphiboly in Aeschylus, who pictures Zeus as the master of the Moirai at one place (Aesch. Cho. 306 f.; Supp. 524 ff.; 822), and as subject to their whims at another ( $P V 516 \mathrm{ff}$.). He also problematizes the issue in the discussion between the chorus and Prometheus (PV 511-518), where Prometheus holds Moira, 
So there may be room for a different approach. If we fail to make progress by means of a semantic analysis, perhaps a functionalist one may bring relief. It is obvious that all expressions under discussion share the functional nature of belonging to a fixed formulaic stock of pleas for excuse. Our passage is most explicit in this respect. For after having introduced the disastrous effects of the allied forces of Zeus, Moira and Erinys, Agamemnon continues: "What could I do? (modern Greek: $\tau^{\prime} v \alpha$ кó $\left.v \omega ;\right)$ God (deity, divine power) accomplishes

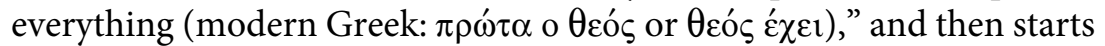
a fresh, extensive, excursus in which Ate gets the blame for his own illconsidered behaviour. Similar references to a superior steering principle in terms of god, the gods, daimon, fate, fortune, chance ${ }^{45}$ abound in archaic poetry, and not only there, functioning either as strategies to make sense of-and hence provide an excuse for-unaccountable self-damaging conduct, or as a formula of resignation or solace in a situation of undeserved misfortune. ${ }^{46}$ As a matter of fact Agamemnon specializes in the use of such excuse formulas. ${ }^{47}$

who is implicitly identified with ananke by the chorus, responsible for his sufferings, after which he says that Ananke is directed by the "three Moirai and the remember-

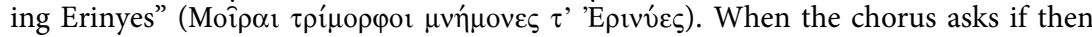
they are stronger than Zeus, his answer is: "Even he could not escape that which is

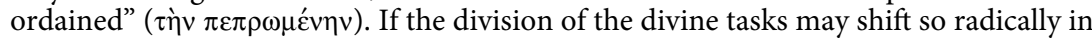
one passage where they are the subject of an analytical discourse, what can we expect from a passage in Homer? See Groeneboom a.l. and especially Griffith 1983, 18, on the shifts in the $P V$ : "and, as so often in tragedy, overall responsibility for the general workings of the universe, and the particular workings of the play, cannot be laid on any single person or power." The alternations between Zeus and Moira are a never ending story. See e.g. the significantly inconsistent phrasing of H. Orph. 59, 11-14, "Moira is the only one ( $\mu$ óv $)$, and nobody else of the immortals, who looks after humans' lives. And Zeus's perfect eye. Because whatever happens to us, it is Moira and the mind of Zeus who knows (oî $\delta \varepsilon$, singular!) everything." Later still: Banfield 1958, 108, on modern rural South Italy: "God exists and deserves respect. But there is no use trying to gain his favor by worship," quoting a peasant: 'God is luck, and if luck could be managed by intention, it would not be luck.'” And ibidem p. $124 \mathrm{f}$. on the arbitrariness of God's decisions: "He may distribute bounty or catastrophe according to his whim."

${ }^{45}$ Instances of god, the gods, daimon etc. who are taken to be responsible for unaccountable acts or events in Dodds 1951, 4, 11, 12; Chantraine 1954, 49-56.

${ }^{46}$ The 'excuse' motive might be taken as addressed to a 2 nd person, the 'resignation' one rather to the 1st person (the speaker himself) in the terminology of Seitel and Lardinois, as we shall discuss below n. 175. In this respect it is important to emphasize that these strategies of exculpation are nearly always on the lips of the characters, and not launched as author's comments, as e.g. Chantraine 1954, $51 \mathrm{f}$. emphasized for the use of daimon. There is a certain correlation between these excuses and 'white lies', which in modern Greece may serve the same goal, namely "to conceal an inability to 
On a psychological level, then, blaming a divine power is a device for simultaneously acknowledging one's own acts as errors (implying at least a whiff of one's own accountability) and attributing the cause of it all to another agent. From a functionalistic perspective I would suggest we understand references to 'the god', 'the gods', and particularly ate in such expressions as devices to facilitate such a 'double entendre'. Albeit not releasing the offender from his responsibility and his duty to redress it, this excuse formula may help both to save his face and to open up avenues in the social process of reconciliation, as it indeed works out several times in the Iliad ${ }^{48}$ Hence, assessing the formulas from this socio-functionalist angle rather than (solely) through a-so far obstinate and unsatisfactory-semantic analysis may open a more

live up to the highest requirements of the social code as well as to conceal unintentional failures," as discussed by du Boulay 1976, 400-404. Cf. Barnes 1994, 72-75, and, very instructive on modern Near Eastern lying strategies, M. Gilsenan, Lying, Honor, and Contradiction, in: B. Kapferer (ed.), Transaction and Meaning: Directions in the Anthropology of Exchange and Symbolic Behavior (Philadelphia 1976) 191-219, on lies that become vital in situations on the brink of "successful maintenance or degradation of self" when, "at the terminal point of crisis, room for maneuver and redefinition has vanished and persons can no longer keep it socially invisible." As such these lies, too, are socially accepted or at least expected, hence condoned.

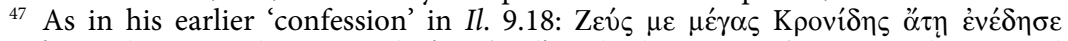

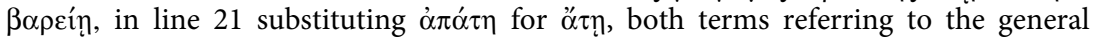
frustration of his expectations concerning the success of the whole expedition (as it

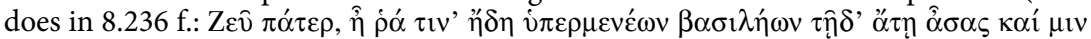

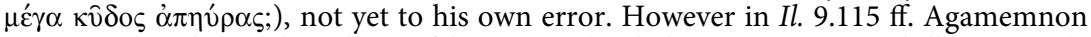
accepts Nestor's good analysis of his ate in his behaviour versus Achilleus, openly

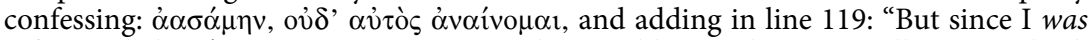
infatuated ( $\alpha \alpha \sigma \alpha ́ \alpha \eta v$ again) giving in to a lamentable impulse, I am willing to go back on it" (and appease Achilleus with gifts). See O. Taplin o.c. above n. 28 for a very personal and modern critique on such behaviour.

${ }^{48} \mathrm{Il} .9 .496 \mathrm{ff}$., in the words of Phoenix, provides the relevant theology in the unique allegorical description of Litai (Prayers of repentance), daughters of Zeus, who liter-

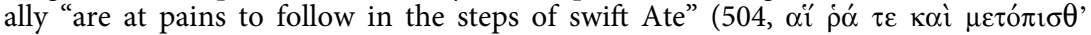

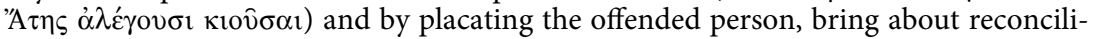
ation and restored communication: "They heal again [the harm done by Ate]" (507,

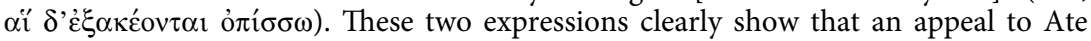
as explanation of unaccounted misconduct functions as an appeal to appeasement and restoration or relations. N. Yamagata, Ate and the Litai in Homer's Iliad, in: E. Stanford \& J. Herrin (edd.), Personification in the Greek World: From Antiquity to Byzantium (Aldershot 2006), argues that in this passage it is Achilles himself who 'personifies' Ate in that he is taken as the model for the description of the goddess. On Litai in relation with dikè see: $\mathrm{D}$. Aubriot, Les Litai d'Homère et la Dikè d'Hésiode,

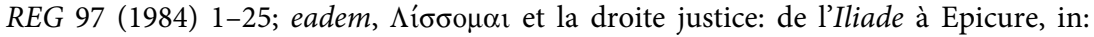
$\mathrm{J}$. Brunschwig et alii (edd.), Histoire et structure, à la mémoire de V. Goldschmidt (Paris 1985) 27-42. 
promising avenue to attain an appreciation of this enigmatic multiplicity of causation.

Significantly, we do not find comments on such face saving strategies of excuse in the Homeric epos itself. They are taken for granted and never provoke discussion. There is only one exception: the critical note by Zeus, in the first book of the Odyssey that we have seen earlier, in which he lodges a complaint against this type of impious mud flinging by mortals in distress. Later writings, on the other hand, abound in critical, not infrequently scornful, comments on such behaviour. Scholia ad loc. for instance note: "Even now those who cannot defend themselves by the simple truth lay the whole blame on fate" ( $\tau \hat{n}$

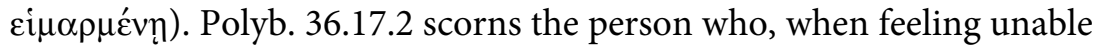
to find the cause of events "puts the blame on the god and on fortune"

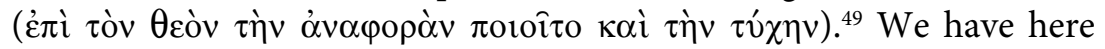
a Hellenistic 'translation' as it were of the Homeric couple Zeus and Moira, also here connected by the word 'and'-not 'or' - but this time denounced by a critical outsider. If in this case modern scholars are less prone to launch a search for a 'theory' behind the relationship of the two, this may be due to the enormous amount of relevant information available. In the Hellenistic and Roman periods this type of potentially inconsistent blame attribution proliferates in often unsophisticated funerary inscriptions and epigrammatic poetry on the one hand, and is well-represented in the criticism of contemporaneous philosophical treatises written by intellectuals who try to create order in this supernatural chaos, on the other. Why do we stubbornly persist in interrogating Homer on questions of semantic coherence which nobody would tend to press in these later texts? Are we perhaps trying to save the Poet from the verdict of lack of sophistication by trying to exact a theological/philosophical reflection from his text? Do we fear, perhaps, that lack of a logical system in these formulas of excuse might affect their credibility in the eyes of either the addressee or the ancient

${ }^{49}$ Cf. Wallbank comm. ad loc. 10.5.8. For more examples in Polybios see idem, vol. I p. 22, on, for instance, people who attribute what is really due to an individual's

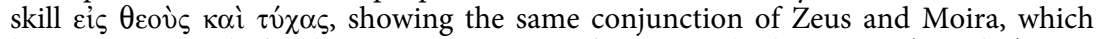

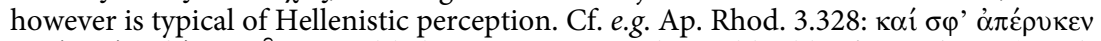

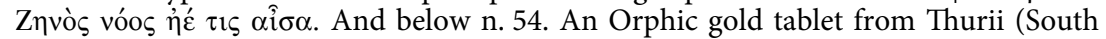
Italy) (A. Bernabé, Orphicorum et Orphicis similium testimonia et fragmenta 1, 2 [Munich-Leipzig 2004-2005] no. 489B) has: "Either Fate mastered me or the lightning bolt thrown by the thunderer." 
reader/listener or both? Let us consult some specialists on formulas of excuse.

Herzfeld 1982 is a revealing study on the modern Greek social practice of excusing various kinds of failure or misconduct by referring them to the influence of supernatural, uncontrollable agents. At p. 645 we read:

Whether people believe them or not, they are evidently willing to countenance such excuses, provided only that the excuses exhibit certain appropriate, stereotypical characteristics. To focus on the credibility of the excuses thus seems a red herring; their acceptability which is far more easily demonstrated, still demands an explanation. Indeed, acceptability is a precondition for credibility. ${ }^{50}$

Now, this acceptability, as Austin 1971 in a path-breaking study had argued, is far less concerned with the logical, argumentative qualities of the formulas themselves than with the social codes of acceptance of traditional formulas and their ability to draw on a substratum of ideas about causation, even though these ideas may belong to long forgotten or radically transformed systems of thought. There may be etymological connections involved-Austin pp. 99-100 speaks of 'trailing clouds of etymology'-but "they are a form of indirect allusion. They are not links between referential meanings as such." Or once more in the words of Herzfeld 1982, 667:

${ }^{50}$ The theme is also at issue in theories of cognitive consistency. Human behaviour obeys an 'internal logic', or 'psycho-logic' rather than a formal logic. See: R.L. Atkinson \& R.C. Atkinson et alii, Introduction to Psychology (Orlando 1993) $728 \mathrm{f}$. Abelson (1968) 112-139 proposes that many of our attitudes come packaged as opinion molecules. Each molecule is made up of (a) a belief, (b) an attitude, and (c) a perception of social support for the opinion. (.....) Opinion molecules serve important social functions. First, they act as conversational units, giving us something to say when a particular topic comes up in conversation. They also give a rational appearance to our unexamined agreement with friends and neighbours on social issues. But most important, they serve as badges of identification with our important social groups, reinforcing our sense of belonging to a community. Not unrelated but more wide-ranging is the concept of "cultural model" introduced by N. Quin \& D. Holland (edd.), Cultural Models in Language and Thought (Cambridge 1987), which they define as a narrative, prototypical, schematic, and simplified form of social knowledge, available to interpret events. Particularly relevant to our topic is their stressing of the simultaneity of a variety of cultural models (pp. 6-8). At p. 10 they claim: "That there is no coherent cultural system of knowledge, only an array of different culturally shared schematizations formulated for the performance of particular cognitive tasks, accounts for the co-existence of conflicting cultural models encountered in many domains of existence." 
The key question thus shifts from how belief in fate influences action, to how declarations about fate constitute a form of action-the performative action of excuses. Instead of literal statements of belief in fate, it addresses performances that invoke the idea of fate through oblique allusion. ${ }^{51}$

So I would suggest we take a pause in feeding red herrings to Homer, and stop hassling the author by confronting him with questions which, not being a philosopher nor a literary critic, he simply had no inclination to contemplate at that special moment and in that context. ${ }^{52}$ Later in this chapter I hope to demonstrate the consequences of such (un)scholarly behaviour. At this point I restrict myself to citing the final verdict by Herzfeld: "In such a context, the ethnographer's questions about belief in fate are impertinent both socially and methodologically." ${ }^{33}$ In the view of an anthropologist, then, Agamemnon's appeal to Zeus and Moira and the Furies (and Ate) is basically nothing more than an adaptation of a common formulary strategy. Agamemnon just lists the divine instances who conventionally share the function of being targets for blame attribution in pleas for excuse. One type of adaptation may be seen in the poet's freedom to weave an elaborate narrative on any one of them, as he does here in the case

${ }^{51}$ The inspiration of performative working of language is of course derived from J.L. Austin, How to Do Things with Words (edited by J.O. Urmson \& M. Sbisá, Cambridge Mass. $1975^{2}$ ). Cf. R. Bauman, Verbal Art as Performance (Rowley MA 1977).

${ }^{52}$ In later Greek literature the problem inherent in multiple causation may be resolved or made explicit as for instance in Eur. HF 20-21, "whether subdued by Hera and her goads or by necessity," where the overdetermination is implicitly invalidated

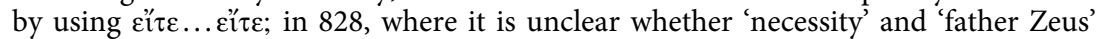
are mutually identified or united. The famous verse 1135, where the question "who killed these children" is answered with "you and your bow and of the gods whoever

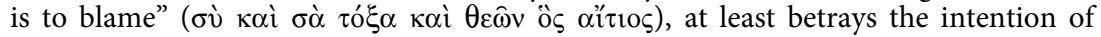
prompting the listener to reflection. See: G.W. Bond, Euripides Heracles (Oxford 1981) a.l. with many parallels. In the Phoenissae 350-353, Iokaste sums up the causes of the afflictions scourging the city of Thebes: "whether it is the sword or strife or your father to blame; or whether the gods (to daimonion) have reveled destructively against the

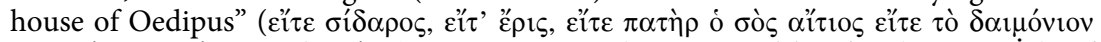

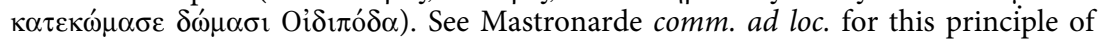
"multiple causation." He suggests that 'iron' may be malevolent magic. Cf. also Eur.

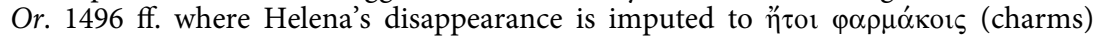

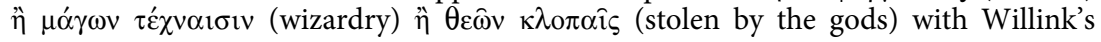
note.

${ }_{53}$ Cf. J.F. Holleman, Accommodating the Spirit amongst some North-Eastern Shona Tribes (London 1953) $35 \mathrm{f}$., who argues against asking non-Western (including early Greek) people direct questions, "because it places them in a realistic frame of mind. They are forced to analyse, define and distinguish with a critical mind what is essentially vague, undefinable and largely emotional." 
of Ate. Another adaptation is the extraordinary accumulation of the blame targets, which may have been inspired by the excessive consequences of his unfortunate behaviour and the extreme necessity to redress the situation. In other words, Agamemnon resorts to redundancy, or, in the words of Dodds, extreme 'overdetermination', keeping all options vague, but open. ${ }^{54}$

If, nonetheless, we still cannot restrain ourselves from hunting for an explanation-in particular for the presence of the Erinys-and do not find convincing evidence of comparable activities for her elsewhere in the Homeric epic, we may consider that this is an additional and rather daringly novel strategy of overdetermination. To the irreducible will of Zeus, which may turn out positive or negative, and the irreducible but nearly always fatally detrimental ways of Moira, one definitely and exclusively retributive authority is added. This, however, would entail the assumption that she is hunting down Agamemnon for something (anything) within his own responsibility that may have happened prior to Il. 1.1 and of which he himself may be and the reader/listener definitely is unaware. ${ }^{55}$ Quite some argumentum e silentio. One aspect of Erinys may have further fostered the choice: besides Zeus she is the only other divine agent that once "led heavy Ate" upon a person $(\mathrm{Od}$. 15.234) in a phrase very similar to our passage, an aspect which was

\footnotetext{
${ }^{54}$ Just as in our culture a person who has been threatened with a knife by the neighbour at whose door he was complaining about the decibels produced by his TV, may explain later: "Thank God, by a lucky accident a friend of mine chanced to pass by, knocked out the bastard and rescued me. Fortunately, there is still justice." Dodds borrowed the concept 'overdetermination' from the field of psychology (see Dodds 1951, 30 ff.). The most explicit instance in the Iliad is at 16.849, $\dot{\alpha} \lambda \lambda \alpha_{\alpha} \mu \varepsilon$ Moîp' ó $\lambda$ ò

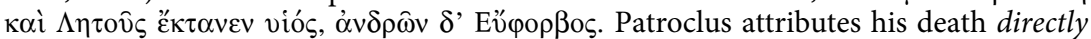
to the immediate agent the man Euphorbos, and indirectly to the mythological agent Apollo, but from a subjective standpoint to his bad moira. Cf. such instances as Diomedes' remarks that Achilles will fight "when the thumos in his chest tells him to and a god rouses him" (Il. 9.702). Cf. Il. 18.119 (Moira and the wrath of Hera); 21.84 (Moira and Zeus, who surrendered me to your hands); 22.297-303 (Theoi, Athena, Zeus and Apollo, Moira). R.K. Fisher, The Concept of Miracle in Homer, Antichthon 29 (1995) 1-14, espec. 5, on overdetermination: "It is about the drawing on different points of view or levels of interpretation which are understood to describe events in their own terms, but which may not necessarily rule out other terms of description with their own validity." Generally he concludes: "The event is doubly determined, on the natural and on the supernatural plane."

${ }^{55}$ One may compare proverbial expressions such as "which god did we offend, that we are suffering this?" as we discussed in our first chapter p. 43.
} 
readily exploited in later literature where the Furies were thought to strike their victims with mania. ${ }^{56}$

While the psycho-social function of the plea for excuse can be ascertained beyond serious doubt on account of both context and explicit textual information, suggestions about the semantic coherence of the divine actors in cases like the present one can never elude the dilemma of whether they are a re-construction of the author's intention or a modern construct, the product of the reader's creative imagination. This, of course, is the key problem of literary criticism and hermeneutics in general. ${ }^{57}$ Or rather, it should be, for, as we shall have ample occasion to observe, this is not every philologist's most pressing concern. Hence, this dilemma will re-emerge time and again in the present chapter.

Dodds (p. 4) seems to have realized this. In a comparable case of excuse formula he wondered: "are we dealing with anything more than a façon de parler?" Now, more than fifty years later, I myself would like to reformulate this as a question serving my own line of interest: suppose we discover that we are dealing with a way of speaking, a maxim, aphorism, saying, dictum, as I have just argued, do we need more to make this discovery worthy of scholarly interest? ${ }^{58}$ Is the qualification 'a way of speaking' the end or perhaps the starting point of further reflection? We have taken cognizance of the opinion of some modern experts. In the present chapter I will argue that downplaying the specific archaic Greek way of coping with the inscrutable ways of 'the gods' is one of the surest means to miss the core of much of what we would call Greek religion. Their 'way of speaking' is far more essential

${ }^{56}$ The Erinyes were worshipped under the name of Maniai at Megalopolis (Paus. 8.34.1). See on the relationship of ate and the Erinyes in Greek literature, especially tragedy: Padel 1992, 162-172.

${ }_{57}$ As is occasionally acknowledged. M. Frede \& G. Striker, Rationality in Greek Thought (Oxford 1999) for instance show that ancient texts have often been misinterpreted through the influence of modern ideas of reason, and seek to redress the balance. M. Heath, Unity in Greek Poetics (Oxford 1989) made it the core of a comprehensive critique. Recent attempts to re-construct the principle of polychromy in Greek monumental art after the 19th century construction of the Greek aesthetic ideal through misreading its 'blank' intentions ever since Winckelmann, are a perfect illustration of what I am saying. See: R. Panzanelli, E.D. Schmidt \& K. Lapatin (edd.), The Color of Life: Polychromy in Sculpture from Antiquity to the Present (Los Angeles 2008).

${ }_{58}$ And not only because "even a façon de parler must have an origin" (Dodds 1951, 5). 
to a productive understanding of Greek religion than we may have realized.

Before we continue our explorations, however, I would like, just for a moment, to pay attention to a second riddle in the passage under discussion, less, if at all, examined in modern commentaries. It is the question about the identity of "the god who accomplishes everything" who is mentioned after Zeus, Moira and Erinys, and before Ate. The question would be hardly worth asking in the case of the 'great God' referred to by the speaking horse, Xanthos, who is obviously Zeus, or in the numerous Homeric passages where theos or theoi (and even Zeus) are just generic expressions denoting 'supreme anonymous supernatural steering power'. ${ }^{59}$ In our passage, however, the question is prompted by the complexity of its context. Even if he had wished to, Homer himself could not have helped the reader since he 'lived' in an age before punctuation (as well as before writing). It is the modern need to punctuate that reveals the problem. Some editors put a period after $\tau \varepsilon \lambda \varepsilon v \tau \hat{\alpha}$, implying that a divine principle different from Ate must be intended. Others print a comma, or even more explicitly the Greek equivalent of a colon, obviously thinking that the expression must refer to the following Ate. ${ }^{60}$ The choice for a period involves two possible interpretations: a) theos is just the general proverbial expression of anonymous divine authority and nothing more; ${ }^{61}$ b) theos may be taken as a comprehensive term, here in particular encompassing the three preceding different notions Zeus, Moira, Erinys. These two options, though not constituting a particularly happy alliance, are not necessarily incompatible in that both represent a closing comment on what has been said before. On the other hand, both are incompatible with the third, prospective one, which identifies theos with the

${ }^{59}$ Else 1949; François 1957, 21-47, and cf. the next section of this chapter. O. Tsagarakis, Nature and Background of Major Concepts of Divine Power in Homer (Amsterdam 1977), is far from proving his thesis that theos and theoi never stand for a divine abstract but presuppose familiar gods without commitment to a precise identification. Even less is it self-evident that theos in our passage should be "not a god or any god but the god par excellence, i.e. Zeus," as he argues at p. 80. And this is not the only weakness of this book as critics have not failed to point out.

${ }^{60}$ "By $\theta \varepsilon$ có he could have meant ö $\tau \eta$ :" Dietrich o.c. (above n. 42) 203 n. 2. This is the explicit view of Ahrens 1937, 32, who takes the total expression, from $\theta$ cós till $\dot{\alpha} \alpha \hat{\tau} \alpha 1$, as a gnome.

${ }^{61}$ E.g. J.U. Faesi, Homers Iliade II (Leipzig 1855) 238, "im Allgemeinen: die höhere,

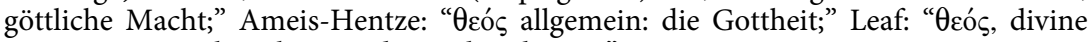
power, is not to be taken as identical with 'A $\tau \eta . "$ 
following Ate. ${ }^{62}$ The qualification of 'eldest daughter of Zeus' is virtually incompatible with her being theos either in the pregnant gnomic meaning or in the comprehensive meaning which would include Zeus, as for instance Leaf ${ }^{63}$ reminds us. Once again we are confronted with an insoluble problem. For what has to be ruled out from a semantic point of view appears to be required by the syntax, which simply does not seem to tolerate an alternative to equating, or at least relating, theos with the gods mentioned just before and with Ate, which follows, immediately and asyndetically, standing in full syntactic dependence on the preceding line as it-necessarily-is taken by most translators.

One can imagine three different approaches to deal with the aporia. One is to push as hard as intellectually possible-or harder-in trying to reconcile the irreconcilable through ingenious conjectures. I have not seen a successful one: the scholia in particular are exemplarily ingenious and deterring. ${ }^{64}$ Another is to conclude that there is something very suspicious about the constitution and tradition of the text, which, with respect to Homeric epic, usually equals 'later insertion'. Though opposites, both strategies are equally characteristic of the modern mind. The third suggestion might be that the principle of free association, offered, perhaps rather prompted, by the general denotation of theos, allows for an even greater variety of implementations than one might have imagined. The author may indeed have seized the opportunity to create a sudden and unexpected implementation ${ }^{65}$ even if it yielded unmanageable internal inconsistencies with other parts of his text. As it did. In this view the term theos, which autonomously may function as a general gnomic notion, by its context attracted the function of a trait-d'union between the preceding and the following, with an unpredicted (and probably unintended) but highly productive result. Retrospectively it may be seen as referring back to Zeus, Moira

${ }^{62}$ This becomes apparent by the urge to provide Ate with a verbal form like $\dot{\sigma} \sigma \tau i$. So older editors i.a. Faesi, Monro, La Roche.

${ }^{63}$ Comm. ad loc. Implicitly Dodds is of the same opinion when he calls Ate not a personal agent, but a "transparent piece of allegory" (above n. 29).

${ }^{64}$ The scholia fully acknowledge the problems of the text constitution. One proposes to read $\theta \varepsilon o$ ì $\delta$ ì , giving the sense: "through the gods everything comes to completion." Another reads $\theta \varepsilon o ́ \sigma \delta 1 \alpha=\theta \varepsilon o ́ \sigma \delta o \tau \alpha$. Particularly ingenious is the suggestion

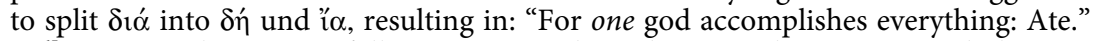

${ }^{65}$ I see no objection to following Aristarchos who, according to some scholia, says that some things are due simply to chance inspiration ( $\kappa \alpha \tau^{\prime} \dot{\varepsilon} \pi$ ' should not look for ulterior reasons for them. See: N.J. Richardson, Literary Criticism in the Exegetical Scholia to the Iliad, CQ 74 (1980) 264-287, espec. 271. 
and Erinys. In a prospective view theos could be taken as semantically cleared-like a palimpsest-and thus rendered available for a new script: ${ }^{66}$ ate, which accordingly-if not consequently-is promoted from an abstract notion into a divine figure during the process. ${ }^{67}$

We thus see three different agents-a more or less personal supreme god (Zeus), Fate (Moira) 'that what is destined for a person', and a personalized principle of retaliation (Erinys) - in paratactic co-operation sending the instrumental agent ate, which/who after meeting the other three in the central niche 'theos' steals this predicate and the show and continues her life as a personal divine actor. All this in a few lines by one author. I could not think of a better introduction to the main theme of the present chapter.

So far we have found ourselves confronted with expressions that cover a variety of different explanatory notions on a scale stretching from unpredictable destiny, fate or chance, via an arbitrary rule of supernatural agents referred to as Zeus, the god or the gods, to a belief in the justice of a divine supreme being. We have seen these different, mutually contradictory concepts as separate elements scattered throughout archaic literature. They often prevailed in one author or one work. Once, in the Homeric passage, we saw them juxtaposed in close, hence alarming, adjacency. Things will become more complicated

${ }^{66}$ In a fascinating interpretation of Herakleitos B1, D. Sider, Word Order and Sense in Heraclitus: Fragment one and the River Fragment, in: K.J. Boudouris (ed.), Ionian Philosophy (Athens 1989) 363-368, in the wake of Gigon e.a., argues that ócí does not refer either to the preceding or to what follows but does both $\dot{\alpha} \pi$ ò кovvov. And he argues the same for another fragment. In view of Herakleitos' preference for philosophical amphibolies, he argues that this is no doubt intentional. In the case of an oral and improvised type of poetry like the Homer epics one would rather think of a spur of the moment association.

${ }^{67}$ To be frank, I could hardly believe this myself, when I wrote it in 1996. Years later some colleagues (see below n. 182) drew my attention to recent work on the implications of the notion 'speech' for archaic poetry (see more extensively: below p. $226 \mathrm{ff}$.). Slings 1999, espec. $23 \mathrm{f}$. made the scales fall from my eyes. Speaking on a line of words, which in a rather harsh way change their syntactical condition (from apposition to a word in the preceding line, into becoming the subject of the following one, as in Mimn. fr. 1. 1-4, including the ensuing problem of punctuation) he explains: "In spoken language, dual functionality is a perfectly normal phenomenon; it is one of the manifestations of a more general trait of spoken language: a speaker starts a clause complex in a certain way, and half-way through it, given the fallibility of human memory, he changes course and ends in a different way. (....) Human memory is fallible." This is directly relevant to the exactly similar text- (rather: speech-) constitution under discussion. 
in a few celebrated passages of two authors, Herodotus and Solon, to which we shall now turn.

We also have detected a first glimpse of the cultural-rhetorical setting that may, if not explain the semantics, then at least provide an insight into the possible origins and background of the alarming concatenation of such conflicting representations. After analysis and discussion of each of the following passages, we will step by step continue our enquiry into the socio-cultural embedding of the different expressions and so hope to advance our insight into the enigmas that we shall encounter.

\section{Herodotus}

\section{Two tales, many perspectives}

Two famous logoi (episodes) of Herodotus' Historiai display a strong thematical and structural likeness, namely the story of Polykrates' attempt to prevent his inescapable downfall in 3.40-43, and a set of even more celebrated, interrelated passages concerning the life of Croesus, namely the story of Solon's lesson to Croesus (1.32-34) and the account and interpretation of Croesus' downfall (1.86-91).

Both stories take their point of departure in the deep-rooted Greek conviction, typical of Herodotus in particular, that excessive luck, wealth, or power is inevitably followed by an (often sudden and unexpected) 'catastrophe' in the twofold sense of reversal/upheaval and ruin/downfall. The explanations of inescapable doom scattered over these passages are articulated in a great variety of divergent expressions, which will be cited in the order of their entry in the narratives. Such a comprehensive survey may seem pedantic, even superfluous, and perhaps for that reason will not be easy to find in earlier studies. Yet, to my mind it is an indisputable prerequisite for conducting a scholarly analysis. One reason is to avoid the often unconscious preliminary decision to ignore some expressions as having less emphasis, being 'unmarked' or otherwise semantically less dominant, and hence to exclude them from the discussion. Another reason is that nearly all the explanations collected in my survey also return in other passages of Herodotus and that all of them can be attested in other authors, especially those of the archaic period, but with one exception never in such a dense accumulation and rapid succession. The only exception is Solon's so-called Hymn to the Muses, which will also be discussed. 
The two Herodotean logoi share three themes: an expected or realized catastrophe, attempts to account for it, and the central role of excessive luck as apparent from wealth or power. They also share the motif of a 'tragic warner', whose task it is to express his concern about the imminent vicissitudes of the excessively fortunate protagonist, and who may even offer a suggestion for escaping the impending doom. In both stories the warner fails, indeed in accordance with the central message must fail, to sway the course of events. ${ }^{68}$

In the first $\log o s{ }^{69}$ Polykrates, the fabulously wealthy and powerful tyrant of Samos in the sixth century BC, receives a warning from his friend Amasis, king of Egypt, who is worried about his great luck because

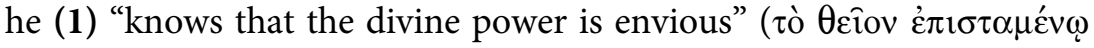

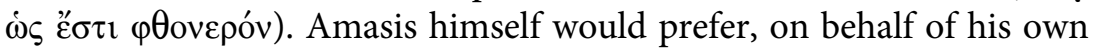
life and that of the ones he cares for, (2) "to do well in some things and badly in others, passing through life with alternate success and failure, rather than to be always lucky in all respects" (

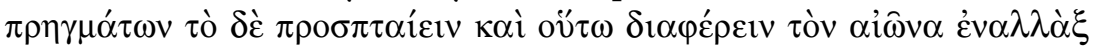

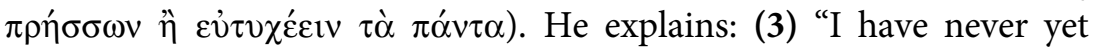
heard of a man who after an unbroken run of luck was not finally

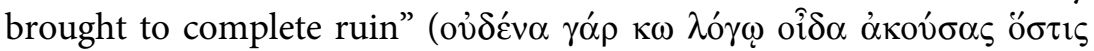

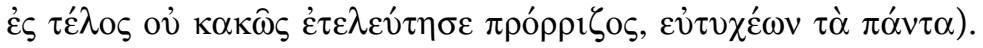

Polykrates is advised to redress the situation by abandoning the possession he values most, and to continue this 'mending' strategy

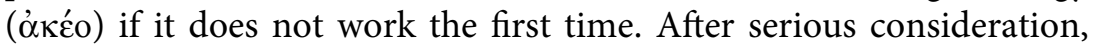
Polykrates selects as his most precious possession his personal ring, and throws it into the sea so as to visualize and realize its irretriev-

${ }^{68}$ On the role of the warner in Herodotus: H. Bischoff, Der Warner bei Herodot (Marburg 1932); R. Lattimore, The Wise Adviser in Herodotus, CPh 34 (1939) 24-35. A poignant summary in E. Visser, Herodots Kroisos-Logos: Rezeptionssteuerung und Geschichtsphilosophie, WJA 24 (2000) 5-28, espec. 27: "Die Warner sollen dem Leser zeigen, wie weit sich der Protagonist von dem Gefühl einer grundsätzlichen Verunsicherung, die doch als condicio humana einem Menschen ständig bewußt sein müsste, entfernt hat." On 'warning' the reader through signals in the narratio: Cf. H. Schwabl, Gyges und Kroisos bei Herodot: Zur 'epischen' Technik von Ankündigung und Ausführung, WS 117 (2004) 31-68.

69 The episode has drawn much attention and raised much discussion. Versnel 1977 discusses earlier views and proposes a new interpretation. For a different view see: J.E. van der Veen, The Lord of the Ring: Narrative Technique in Herodotus' Story on Polykrates' Ring, Mnemosyne 46 (1993) 433-457 = idem, The Significant and the Insignificant. Five Studies in Herodotus' View of History (Amsterdam 1996) 6-22, on which below n. 107. Cf. also D. Ogden, The Crooked Kings of Ancient Greece (London 1997) 119-123. 
able loss. Once back home he grieves for his loss/misfortune ( $\sigma \nu \mu \varphi о \rho \hat{~}$

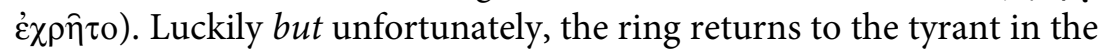
stomach of a fish that is presented to him. Understanding that (4) "this

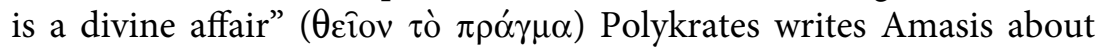
what has happened. The Egyptian king now understands that (5) "it is impossible for a man to save another man from what is destined to

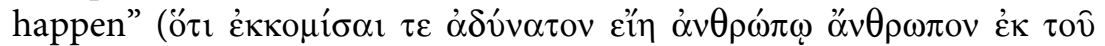

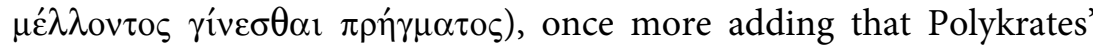
excessive luck and good fortune will inevitably be succeeded by reversal and doom.

We observe five different motifs put forward to illuminate the background and inescapability of the tyrant's final downfall: 1) the jealousy of the gods, 2) the necessity of steady alternation of good and bad, 3) excessive luck must in the end lead to complete ruin, 4) divine intervention, and 5) what is fated to happen cannot be changed.

With the exception of the 'jealousy of the gods' ( $\varphi \theta$ óvos $\tau \hat{\omega} v \theta \varepsilon \hat{\omega} v)$, these notions, as separate thought units, are recurrent motifs in archaic Greek poetry. ${ }^{70}$ Divine envy, often heralded as the most typically Herodotean theme, ${ }^{71}$ did already occur sporadically in Homer e.g. Od. 5.118,

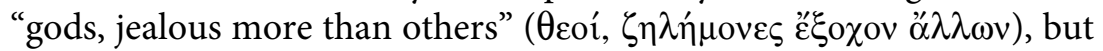
as an explicit notion flourishes not before the later archaic period, perhaps under influence of the image of the tyrant. ${ }^{72}$

70 See Harrison 2000, 38 ff. for the evidence. Cf. below, Ch. III n. 121.

${ }^{71}$ Even though the expression divine phthonos or its cognates occur only five times in Herodotus: twice in the passages under discussion (both times aroused by excessive prosperity); twice in the words of Artabanos, 7.10ع: divine envy as provoked by excessive fortune and 'thinking big' (haughty thoughts), and 7.46.4: the jealous god grants man only a tast of a sweet life ( $\gamma \lambda v \kappa v ่ v ~ \gamma \varepsilon v ́ \sigma \alpha \varsigma)$. Finally once in the words of Themistocles (8.109: 'thinking big'). However, the exclusive location of 'divine envy' in speeches of warning or censure may be seen as underlining its central position in Herodotus' thought. See for earlier scholarship and a convincing refutation of a recent challenge to the importance of divine envy by those who wish explicit affirmation of consent by the author (e.g. Lang 1984, 61; Waters 1985, 99, 104) see: Shapiro 1996, 352-355. Cf. Harrison 2000, 40 n. 26. This does not mean that the author's personal preference for one type of causation ousts others. See below Appendix III. On the more general question whether Herodotus himself endorsed the arguments put forward by his focalisers in the speeches, as for instance broached by Shapiro 1996, see: Harrison 2000, 38 f. and below n. 96.

${ }^{72}$ On earlier occurrence of envy of the gods see: J. Kroymann, Götterneid und Menschenwahn. Zur Deutung des Schicksalsbegriffs im frühgriechischen Geschichtsdenken, Saeculum 21 (1970) 166-179; G.J.D. Aalders, De oud-Griekse voorstelling van de afgunst der godheid, Med. Kon. Ned. Ak. Wet. 38 (1975) 47-65; Lloyd-Jones 1971, 55 ff.; Parker 1997, 151 n. 30. For later periods see Ch. III n. 120. 
The same explanatory devices combined with others return in the other two Herodotean passages announced above, the first concerning Croesus' luck and the anxiety it provokes, the second on his downfall, linked together by the story of the tragic death of Atys.

In the first section of the Croesus $\operatorname{logos}{ }^{73}(1.32-34)$ - "focal point in the whole Croesus logos and one of the most important sources for Herodotus' ethical, religious, historical, and philosophical views" (Asheri 2007, 97) -the wise Athenian statesman, lawgiver and poet Solon pays a visit to the wealthiest man of his time, Croesus, king of Lydia. In his role of tragic warner and triggered by the king, who is irritated by Solon's reluctance to declare him the happiest (ỏ $\lambda \beta 1 \omega \tau \alpha \tau o \varsigma$

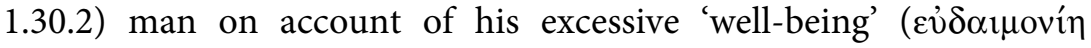
1.32.1-2), the Athenian first tells the famous story of Kleobis and Biton and next offers a disquisition on the whims of fortune. First he notes that "the divine power is (6a) envious and (6b) disturbing"

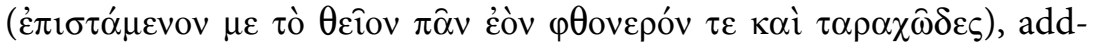
ing that of all (26250 including the intercalated!) days ${ }^{74}$ in a long lifetime "not a single one is like the next in what it brings," which makes

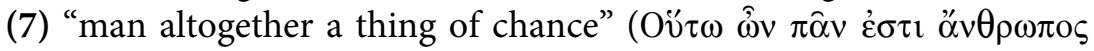

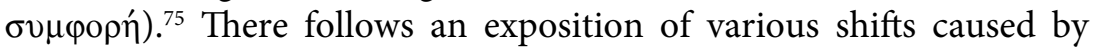
fortune's whims. Nobody can be called happy before the end of his life, since every day may bring a turn in the present situation. The prosperous may end up in misery, the man with moderate means may be more lucky. Nobody can enjoy a complete set of 'happifiers'. ${ }^{76}$

${ }^{73}$ Again a much discussed episode. No general inquiry into Herodotus' views on historical motivation can ignore it. See especially: O. Regenbogen, Die Geschichte von Solon und Krösus, Das humanistische Gymnasium 41 (1930) 1-20, (= Marg 1965, 375-403); M. Miller, The Herodotean Croesus, Klio 41 (1963) 58-94; T. Krischer, Solon und Kroisos, WS 77 (1964) 174-177; W. Marg, 'Selbstsicherheit' bei Herodot, in: Marg 1965, 290-301; von Fritz 1967, 217-223; H.-P. Stahl, Learning through Suffering? YClS 24 (1975) 1-36; Chiasson 1986. For more recent literature and a full discussion see: Shapiro 1996; Harrison 2000, 31-63; Pelling 2006. On the different stages of the historical tradition of the Croesus-Delphi logos see: W. Burkert, Das Ende des Kroisos. Vorstufen einer Herodoteischen Geschichtserzählung, in: Catalepton, Festschr. B. Wyss (Basel 1985) 4-15.

${ }^{74}$ One of the many testimonies that Herodotus had Solon's poems in mind: 70 years also in Solon fr. 27, 17-18. Cf. Chiasson 1986, 254 f.; Harrison 2000, 37.

${ }^{75}$ Literally "a human is altogether symphora." Man and chance are identified here. The term symphora tends to shift from mere 'chance' towards 'disaster'.

${ }^{76}$ The idea remains popular throughout antiquity. When Plutarch De Superst. $167 \mathrm{f}$. discusses "human experiences and actions which are linked with chance circumstances which move now in one course and now in another," he opens the passage with the 
A sound mixture of good and bad is preferable, for (8) "Look to the end, to the final outcome. Many humans the god, after first having granted them a glimpse of happiness, has brought to utter ruin" (

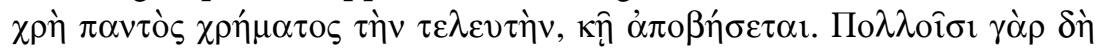

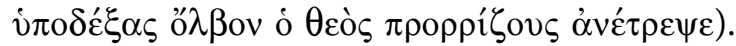

We recognize various themes of the Polykrates logos, sometimes literally, but there are differences as well. Solon mentions two different conceptions: divine envy threatening only the excessively prosperous, side by side with the vicissitude of luck (symphora), which should concern every human being since it works in both directions: from good to bad and in reverse, and also includes various mixtures. ${ }^{77}$ Either of the two-divine envy and chance-often occurs as a general principle in its own right in Herodotus. ${ }^{78}$ So this passage confronts us with twonot necessarily mutually exclusive, yet clearly distinct-explanations of sudden changes in human life, both available as autonomous traditional themes in Greek literature, but juxtaposed here in an ongoing series of arguments. So far the question of human responsibility is not hinted at in Solon's suggestions. However, we have not yet reached the end of the story.

After Solon's departure (1.34), (9) "Croesus was stricken by a great wrath (nemesis) of the god, presumably because he had deemed

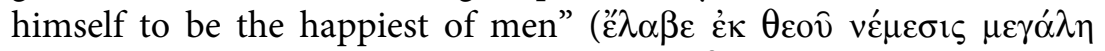

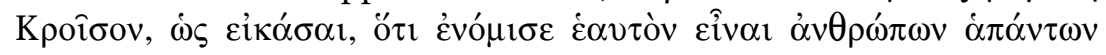

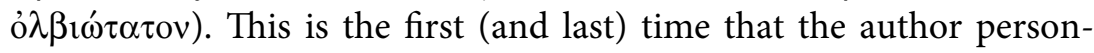
ally interferes in the narrative offering his own, alternative comment

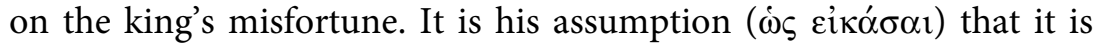
not divine envy but human pride sprouting from excessive prosperity that provoked the reversal of luck as divine punishment. This mirrors

maxim: "it is the common lot of mankind not to enjoy continual good fortune in every respect."

${ }_{77}$ As a matter of fact it is even more complicated than this: the alternation of good luck and bad luck actually is a different argument than the varying mixture of material prosperity and physical or familial misfortune. "The contrast between the "wealthy unhappy men' and the 'lucky men of moderate means' is forced and not consistent with the omnipotence of chance" (How and Wells ad loc.). I will return to several aspects of this later on.

${ }^{78}$ When, later, Croesus gives advice to Cyrus in 1.207, he extends the warning that "there is a cycle of human vicissitudes, and while turning around it does not

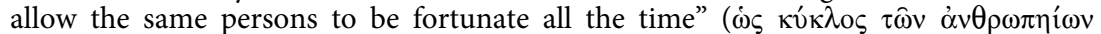

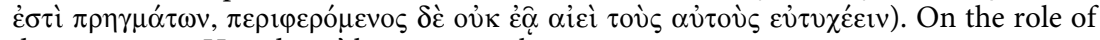
divine envy in Herodotus' history see: above n. 71 . 
the warning against 'haughty thoughts' ( $\varphi \rho o v \varepsilon ́ \varepsilon ı v ~ \mu \varepsilon ́ \gamma \alpha)$ prevailing elsewhere in Herodotus. Here for the first time an element of personal responsibility and, indeed, guilt is introduced as an explanatory device. Accordingly, the competitive notion of divine jealousy here gives way to the retributive concept of divine nemesis. ${ }^{79}$

This divine interference does not yet refer to Croesus' final downfall but to the tragic death of his son Atys brought about by an unfortunate accidental action of a guest (1.34-45). A dream-message portending this violent death makes Croesus do everything to keep his son out of danger. To no avail: he fails to "trick" ( $\kappa \lambda \varepsilon \dot{\varepsilon} \psi \alpha 13.38)$ his son (from death). In a prayer ${ }^{80}$ Croesus calls Zeus to witness, complaining that the murderer of his son had been hospitably entertained in Croesus' own house due to the god's protection. Later on, however, he comforts the innocent murderer with the argument: (10) "This calamity is not your fault: you killed him but not on purpose. One of the gods, I suppose, is to blame, who long ago warned me of what was

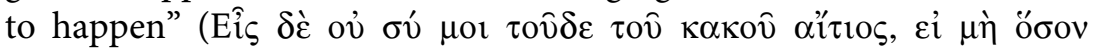

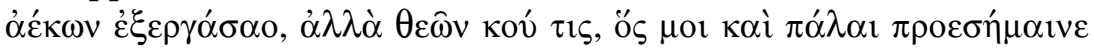

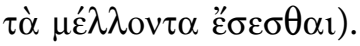

The whole passage is a paradigmatic prelude to the final act, beginning with the story of Croesus' fateful campaign against Cyrus due to his misunderstanding of the oracle of Delphic Apollo and culminating in his confrontation with the Persian king. There we perceive a sequence once more recalling that of the Polykrates logos: a prophecy and its misinterpretation, disaster imputed to, in this case, a specific god, a growing insight-here through divine instruction-about the real multiple causes of the calamity-and the insight that what is destined cannot be escaped.

This final great passage of the Croesus logos (1.86-91) pictures the Lydian king utterly degraded as captive and slave of the conqueror of his empire, standing in chains on a pyre to be burnt alive. This time it is Croesus' own reflections that confront us with another, more bewildering, variety of supposed causes of his destruction, partly in a direct confrontation between the human victim who lacks insight and the all-knowing god who provides it, a new protagonist on the

${ }^{79}$ This means that I do not agree with those who more or less identify nemesis with phthonos here. See: Shapiro 1996, 352 n. 23, and below Appendix III.

${ }^{80}$ Cf. above p. 73. 
scene of life's enigmas. First, in his distress, Croesus realizes that it was by divine inspiration that Solon had said "that no living man was

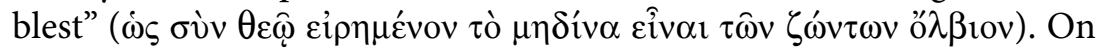
Cyrus' request he then sets out to give an account of that meeting. First, however, the victor, realizing the instability of human affairs, repents and saves Croesus from death by fire (11) "changing his mind... for fear of retribution and realizing that nothing in human life was sta-

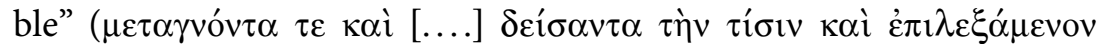

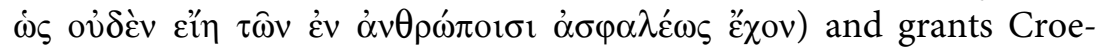
sus freedom to speak, inquiring who had incited him to launch a war against him. Croesus first of all acknowledges: (12) "It was I who did it and brought thereby good fortune to you and ill to myself" ( $\dot{\gamma} \gamma \bar{\omega} \tau \alpha \hat{\tau} \tau \alpha$

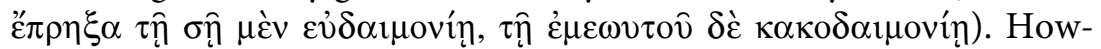
ever, he immediately adds: (13) "but the cause of all this was the god of the Greeks [i.e. Apollo, whom he had honoured more than any other god with gifts and who, he thought, had treacherously promised him a victory] being the one who encouraged me to fight you" ( $\alpha$ ï $\tau$ ios $\delta \dot{\varepsilon}$

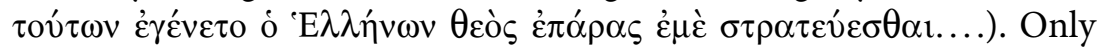
one line further, however, he says: (14) "It must have been the will of [the] gods, I guess, that this should happen" ('A $\lambda \lambda \dot{\alpha} \tau \alpha \hat{\tau} \tau \alpha \delta \alpha$ ' $\mu$ oбí

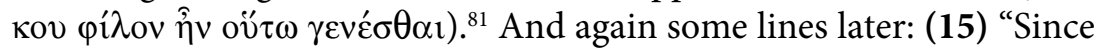

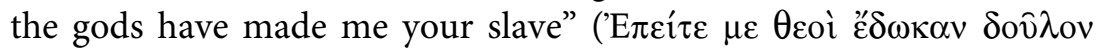
$\sigma 01 \ldots ..)^{82}$

Now it is Apollo's turn for some divine instruction, through the mouth of the Pythia. First he counters the allegation arguing that

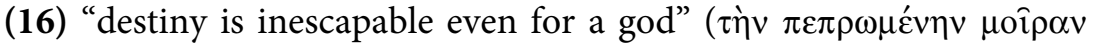

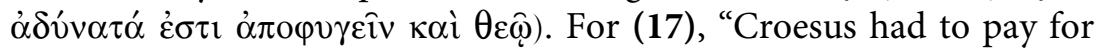
a crime committed by an ancestor of the fifth generation before him"

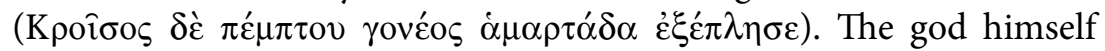
(18) "was unable to divert the Moirai from their course" (oひ้ oió $\varsigma \varepsilon$

\footnotetext{
${ }^{81}$ Note that in this text (14) no fewer than three or four different means are applied to immediately generalize and as it were blur the preceding expression in (13): the omission of the article, the use of the plural, perhaps the choice of the word daimones instead of theo $i$, and, most emphatically, the addition of the word кov, "I suppose," which reminds us of the terminology used earlier by Herodotus when he gave his own opinion. Note, too, that this is the only instance of the plural daimones in Herodotus' work. I cannot go into the intricate question concerning the 'exact' meaning of daimon, and its possible differences from theos.

${ }^{82}$ Note that in a similar situation in 1.207 Croesus says to Cyrus: "Since Zeus gave

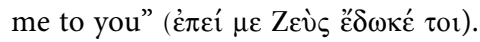




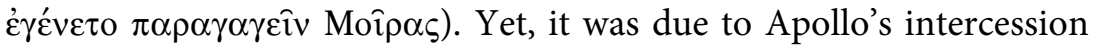
on behalf of Croesus that the Moirai had delayed his 'punishment' for three years. Moreover, the god had saved Croesus from death by fire. After all, it was not the god's fault that Croesus had misunderstood the oracles. And so Croesus gained an insight into the real cause of his downfall and finally (19): "acknowledged that the god was innocent

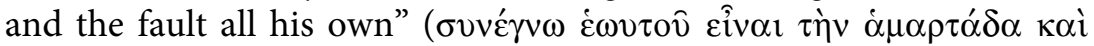

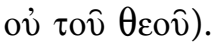

In this section of the Croesus logos, to a certain extent a reflection of the first, we again perceive a choice of considerations, which, roughly following the course of the narrative, can be summarized as follows: 1) retribution/the natural vicissitude of human life (Cyrus), 2) personal human error in a coincidentia oppositorum with the personal action of one individual god, 3) the will of [the] gods in general, 4) the working of predestined and inescapable fate $(2 \mathrm{x}), 5$ ) human culpability, in two different registers: a) the retributive effects of a crime committed by an ancestor, and $b$ ) the personal fault of the victim, more especially his error of judgment caused by lack of insight (2x). It is as if we are seeing Homer in a mirror: Zeus, Moira, Erinys, the god (who accomplishes everything), Ate. And with respect to the entire Solon/Cyrus episode, it is also as if we see Solon himself: most themes collected here can be traced back to his works, especially to the Hymn to the Muses (fr. 13), ${ }^{83}$ as we shall discuss later in this chapter. There can hardly be any doubt about intertextuality here, nor about its recognition by the readers, even if many of the themes were ubiquitous in a wide range of archaic poetry and Herodotus created his own variations and additions.

We can now arrange the Herodotean options on causation of the fall of an extremely lucky, rich or powerful person ${ }^{84}$ in a classified survey of motifs:

${ }^{83}$ This of course has been often recognized: K. Nawratil, Solon bei Herodot, WS 60 (1942) 1-8; P.W. Sage, Solon, Croesus and the Theme of the Ideal Life (Diss. Johns Hopkins Univ. 1985) 47-56; Chiasson 1986, with a well-argued conclusion (261): "the conceptual affinities between them (= Solon's poetry and his speeches in Herodotus) are sufficiently striking to suggest that Herodotus knew Solon's poetry well and attempted, with remarkable historical conscientiousness, to incorporate its most prominent themes into the speeches he composed for the Athenians;" Shapiro 1996. A summary of the similarities and differences in Harrison 2000, $36 \mathrm{ff}$.

${ }^{84}$ The theme never stopped fascinating authors and readers: Th. Wolpers (ed.), Der Sturz des Mächtigen. Zu Struktur, Funktion und Geschichte eines literarischen Motivs (Abh. Ak. Wiss. Göttingen, Phil.-Hist. Kl. 2000 Folge 3, nr. 234). 
I. Impersonal, universal and irreducible laws or principles, not necessarily or explicitly connected with the existence or intervention of gods or a god:

A) Unpredictable and erratic (fate, chance):

I.1 Predestination, fate, what is destined to happen, with emphasis on its inescapability: $5,16,18$.

I.2 Man as the plaything of arbitrary chance, the whims of the day: $6 \mathbf{b},{ }^{85} 7$.

B) More or less predictable:

I.3 The universal law of instability and alternation of luck: 2, 11.

I.4 The extremely lucky or rich will in the end inescapably be brought to ruin (a subtheme of I.3): $\mathbf{3}, \mathbf{8}$.

II. The (arbitrary) intervention of the divine (will of a god or of "the gods"):

II.1 The intervention of one personal god: 10, 13 .

II.2 "The will of the gods" as a general determining principle: 4, $14,15$.

III. The envy of the gods

The envy of the gods uniting the automatic/predictable (I.4) and the divine reactive (II.2) processes into one (divine) principle: 1, 6a.

IV. Human fault resulting in:

IV.1 Punishment for an error or a reprehensible attitude ("haughty thoughts") of the victim himself: 9, 12, 19.

IV.2 Substitutive retribution for an offence of another, especially of an ancestor: 17.

\section{Modern voices: fear of diversity}

This classified survey may serve further reflection. First however, I must prepare myself for the objection that with such schemes one may fall prey to our modern bent for systematization and taxonomy and in doing so impose our principles of organization on an ancient text. ${ }^{86} \mathrm{I}$ should stress then that the scheme should not and does not claim to be more than an arrangement of terms and expressions, listed in the narrative by the author himself, and now arranged in a comprehensive set of categories that can be accepted as the greatest common denominator of each

\footnotetext{
${ }^{85}$ For my arguments that the element $\tau \alpha \rho \alpha \chi \omega \hat{\omega} \delta \varepsilon \varsigma$ in (6b) belongs to this category see: Appendix III.

${ }^{86}$ It does no harm though to call to mind that one of the principal concerns of scholarship is the need for taxonomy. On its fundamental role and import see: J.Z. Smith, Relating Religion: Essays in the Study of Religion (Chicago 2004).
} 
of their meanings. There hardly can be an objection to clustering moira, to peprômenon or to mellon ginesthai by subsuming them under one heading 'destiny,' or 'the predestined', when the author himself twice combines the first two in one expression and twice uses the third as a variant ${ }^{87}$ Nor is there anything against clustering 'the gods' and '(a) god' as semantically identical references to an anonymous divine steering of events, as they abound elsewhere in Herodotus, while accommodating references to an individual personal god, though related, in a different category. ${ }^{88}$ The scheme is not intended to offer suggestions about conceivable interconnections expressed or intended by the author of the various motifs, for this is the subject of current scholarly debate which we shall have to broach now.

At first sight our survey suggests that, though some devices in our modern eyes may seem to be consistent with others, others are less, if at all, compatible, since one seems to exclude the other. And it is the latter category that has become the pet of modern literary criticism. As soon as feelings of uneasiness concerning the consistency in a textual unit emerge, modern readers have a range of hermeneutic strategies at their disposal to allay their misgivings and satisfy their craving for coherence. One is to try to accommodate the different options presented by the author in hierarchical layers or circles, one encompassing, entailing or specifying others. The inescapability of the predestined fate, for instance, representing an all-encompassing frame beyond which there is no beyond, may then be taken as the playground on which various other, more specified, options play their specific roles: envy of the Gods may be viewed as a specification of 'predestined fate', the vicissitude of life's chances as a variant expression of 'what

\footnotetext{
${ }^{87}$ Shapiro 1996, 360 n. 46, lists all 55 passages in which 'fate' occurs in various expres-

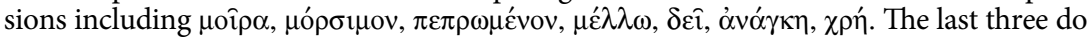
not occur in the passages under discussion. On their specific meanings in Herodotus, see: R.V. Munson, Ananke in Herodotus, JHS 121 (2001) 30-50, espec. 30-36.

${ }^{88}$ The question of the meaning of, and potential differences between, these terms is in the centre of scholarly discussion. I shall pay ample attention to it in the third chapter. For the moment it should suffice to cite the lexicographical data of Powell 1938. 'God' (theos) in what he calls a 'monotheistic' sense occurs 37 times, of which 30 with an article and 7 without. In a polytheistic sense, referring to a specific god, 'a(n unmentioned) god' occurs 116 times; 'mentioned by name' or at least identifiable: 39 ; a goddess 16. In the plural, 'the gods' as a body: 68, of which 25 with article and 43 without. There is, however, a difference between 'the gods' as a comprehensive term and as a collective as I will discuss in Chapter III, where one will also find the more reliable data in François 1957. Cf. also G. Lachenaud, Mythologies, religion et philosophie de l'histoire chez Hérodote (Thèse Paris 1978) espec. Ch. III. 2.
} 
has to be'. But the reverse is also conceivable: divine envy has been roused and will inescapably cause the downfall of the human target. From that moment man lives under a predestined fate. The persistent problem, however, is that in the passages under discussion the author himself unrelentingly refuses to imply his agreement with any of these unifying interpretations. He fails to offer interpretive assistance in any textual form as a glue for sticking different utterances together.

Another strategy is to ask: "Who says what to whom in which context, for what reason, with what intention and with what effects?" These are questions any interpreter ought to consider, and which narratology is helping us to think and phrase in an increasingly sophisticated fashion. ${ }^{89}$ It is narratology, too, that urges us to keep an open eye for different perspectives and contexts, for shifts in focus and positions in the course of the narration. Especially the 'who' is essential: narrator or one of his focalisers? Different viewpoints may be represented by different characters, each arguing from a different perspective. It is remarkable, for instance, that Croesus has a penchant for blaming individual gods for his misfortune. Equally significant, however, is that this is the only type of explanatory device that the author twice explicitly rejects and replaces by one or more different explanations. Similar distinctions in the attribution of a cause of misfortune either to one individual god or to an anonymous authority such as 'the gods' or 'the daimon', as differentiated among different characters or between character and author, are of course well-known from Homer and tragedy, both generally acknowledged as models of inspiration for Herodotus' writing. ${ }^{90}$ However, what is true is not always relevant: in both the Polykrates logos and the Croesus episodes it may be one single

\footnotetext{
${ }^{89}$ I may refer here to the ground breaking works of my compatriot I.J.F. de Jong, Narrators and Focalizers: The Representation of the Story in the Iliad (Amsterdam 1987); A Narratological Commentary on the 'Odyssey' (Cambridge 2001), as well as, particularly interesting for the present chapter: Aspects narratologiques des Histoires d'Hérodote, LALIES 19 (1999) 217-275, and her contribution to Bakker 2003.

${ }^{90}$ On Homer: D. Boedeker, Epic Heritage and Mythical Patterns in Herodotus, in: Bakker e.a. 2003, 97-116. On the tragic nature of Herodotus and the possible influence of tragedy on the author see most recently: Ch. C. Chiasson, The Question of Tragic Influence on Herodotus (Diss. Yale Univ. New Haven 1979); idem, Herodotus' Use of Attic Tragedy in the Lydian Logos, ClAnt 22 (2003) 5-35; J. Griffin, Herodotus and Tragedy, in: C. Dewald \& J. Marincola (edd.), The Cambridge Companion to Herodotus (Cambridge 2006) 46-59; see especially: S. Saïd, Herodotus and Tragedy, in: Bakker e.a. 2002, 117-147. Recently, Sewell-Rutter 2007, Ch. 1, selects the SolonCroesus logos as a chief example of how Herodotus' handling of the divine level of causation resembles the tragedians' use of it. Cf. below nn. 107 and 110 .
} 
character, including the god Apollo, that lists a variety of sometimes divergent explanatory devices.

For the moment we must conclude that we still find ourselves confronted with an odd collection of one author's divergent, sometimes incompatible, suggestions on supernatural, divine, or human causation, which all represent a truth and none of which ousts any other.

\section{Saving the Author}

In Appendix III the reader can find a discussion of two exemplary modern attempts to come to terms with Herodotean diversity. They exemplify the aspirations of the modern literary critic to accomplish his most glorious task: to bring to light a (mostly presented as 'the') underlying coherence of a text, its structuring principles, the connection and subordination of the literary constituents, lines of cause and effect. In sum: to make sense of the text. In doing so, many interpreters take their departure from the almost axiomatic presumption that, always and everywhere, there is a coherence in our sense of that word. It is only under heavy pressure that the most pliable among them may momentarily surrender and pay lip service to the theoretical possibility that it is our sense that is thus being imposed on a text which was not created according to the same principles.

Most readers, including professional readers such as scholars, says Quentin Skinner, ${ }^{91}$ suffer from 'the strain towards congruence', which is constantly nourished by their belief in 'the myth of coherence'. The assumption that as a rule authors command stable, well-considered and consistent doctrines elicits obstinate attempts to "gain coherent views of an author's system." Consequently, "any apparent barriers (...) constituted by any apparent contradictions which the given writer's work does seem to contain, cannot be real barriers, because they cannot really be contradictions. ${ }^{\text {" } 2}$ If, then, a text, a philosophical system or a

${ }^{91}$ Q. Skinner, Meaning and Understanding in the History of Ideas, H\&T 8 (1969) 3-53. For a fundamental discussion see: J.G.A. Pocock, The History of Political Thought: A Methodological Enquiry, in: P. Laslett \& W.G. Runciman (edd.), Philosophy, Politics and Society (Oxford 1962) 182-202. The same for biography: P. Bourdieu, L'illusion biographique, Actes de la recherche en sciences sociales 62/63 (1986) 69-72. A recent discussion of the strength and weakness of the search for coherence: Th. Pollman, Coherence and Ambiguity in History, H\&T 39 (2000) 167-180.

${ }^{92}$ Here Skinner refers to W. Harrison, Texts in Political Theory, Political Studies 3 (1955) 28-44. Cf. also Oudemans \& Lardinois 1987, 43: "We live in a world in which 
historical report reveals an internal contradiction or an inconsistency somewhere, then an almost scholastic conviction that the antinomy must be 'solved', at whatever cost, seems to be the inevitable result. In contrast to this, Skinner pictures the process of thinking as an "intolerable wrestle with words and their meanings". Thus "our attempts to synthesize our views may in consequence reveal conceptual disorder at least as much as coherent doctrines."

In light of our present topic, this may mean that modern readers tend to project their logical 'separative cosmology' onto a Greek multiple 'interconnected' thought pattern, ${ }^{93}$ thus a priori precluding the possibility that ancient Greek cultural phenomena or modes of expression may not comply with our sense of coherence, nor obey our laws of logical consistency. In order to adjust the author's text to our expectancy strategies such as 'creative charity' ${ }^{94}$ or 'creative interpretation' 95 have been developed and are readily exploited. In the words of George Steiner: ${ }^{96}$

Mistake, incoherence and other phenomena that potentially disrupt the picture, will be explained away as due to a lack of effort or understanding on the part of the reader, who will do his utmost to make the pieces fit.

the demand for clear and distinct knowledge precludes the acceptance of genuine contradictions between and within categories (coincidentiae oppositorum) (....) Reality cannot be confused or paradoxical." One of the strategies to counter the tyranny of coherence in historical description is, in the words of $\mathrm{H}$. Kellner, Language and Historical Representation: Getting the Story Crooked (Madison Wisc. 1989), that "what is not straight should be described crookedly."

${ }_{93}$ On these notions see below p. 216.

${ }^{94}$ The term was (re-)introduced by N.L. Wilson, Substance without Substrata, The Review of Metaphysics 12 (1959) 521-539 (after Augustine's regula caritatis). See: I. Sluiter, Metatexts and the Principle of Charity, in: P. Schmitter \& M.J. van der Wal (edd.), Metahistoriography: Theoretical and Methodological Aspects in the Historiography of Linguistics (Münster 1979) 11-27, who ranges it among the strategies "to defend or even exaggerate and to increase the importance of their source," giving revealing examples and a bibliography. Cf. eadem, The Embarrassment of Imperfection: Galen's Assessment of Hippocrates' Linguistic Merits, in: Van der Eijk e.a. 1994, II, 519-535.

${ }_{95}$ As J. Mansfeld calls the strategy that "seeks the interpretation which, in the light of what it knows of the facts, will maximize the truth among the sentences of the corpus." J. Mansfeld, Prolegomena. Questions to be Settled before the Study of an Author or a Text (Leiden 1994) 26; 155 ff., following I. Hacking, Why does Language Matter in Philosophy? (Cambridge 1975) 146-150, espec. 148.

${ }_{96}$ G. Steiner, After Babel. Aspects of Language and Translation (Oxford 1992 $2312 \mathrm{f}$. (cf. 317; 319), arguing that the translator trusts his author, assuming that the latter presents a coherent whole and that what he says makes sense. 
One of these hermeneutic strategies can be viewed in action in Appendix III. There are more. Not only the apparent lack of transparent logical coherence, but also the absence of a connecting word, expression or thought whose presence the commentator needs for making his case may be mended by resorting to the concept of 'implicitness'. Ancient Greek theory of rhetoric already coined the notion of paralipsis $(\pi \alpha \rho \alpha ́ \lambda \varepsilon i \psi 1 \varsigma) .{ }^{97}$ In recent times this device has grown into one of the favourite means to make a text 'say' what it does not say. It has been awarded hermeneutical sanction by defining its purpose in near-Joycean terms as "to grant the hearer the pleasure of finding out himself how things cohere" or to serve "poetic economy and heightening the audience's attentiveness, substituting active involvement for passive consumption." ${ }^{98}$ As such the instrument is both unrivaled and mortally dangerous. ${ }^{99}$ It may solve any (supposed) narrative problem at the high price of yielding fatally arbitrary and unfalsifiable results. To save author and critic, one may rebaptize this draw-back into intentional 'polyinterpretability'. As such it is immediately relevant to our issue: "Herodotus' artistic method is to lead the hearer by what he does not say as much as by what he does," thus Ch. Fornara; "Herodotus is a master in paralipsis," thus I. de Jong. ${ }^{100}$ Small wonder that similar solutions conglomerate in the study of Pindar, whose notorious dearth of textual interconnection makes him an easy prey for specialists in implicitness, and where indeed its applications may be particularly appropriate. ${ }^{101}$ As it may in Herodotus, I hasten to add,

97 LSJ: $\pi \alpha \rho \alpha ́ \lambda \varepsilon \imath \psi \imath \varsigma$ : rhetorical figure in which a fact is designedly passed over, so that attention may be specially called to it ([Arist. Rh.Al.] 1434a25; 1438b6). M. Jahn, Narratology: A Guide to Theory of Narrative (Köln 2006) N3.3.15.

98 Pfeijffer 1999, 25; 28.

99 Cf. above n. 41.

100 Fornara 1971, 61-62; De Jong in an unpublished conference paper. She fully deploys the notion in her A Narratological Commentary on the 'Odyssey' (Cambridge 2001) see p. XIV. See on things that Herodotus does not tell his readers: Immerwahr 1966, 323-326: "the work is highly organized, but in such a way that its order is not immediately apparent." On different types of Herodotean 'difficulties' and their explanations: Lachenaud o.c. (above n. 88) 3 f.; C. Dewald, Narrative Surface and Authorial Voice in Herodotus' Histories, Arethusa 20 (1987) 153.

101 Pfeijffer 1999, 23-34, gives a clear and balanced analysis of the principle of 'implicitness' in this type of poetry, as already acknowledged in ancient (literary) criticism: Theophr. fr. 696 FHS\&G (= Demetr. Eloc. 222); Arist. Rhet. 1400b.26 ff.; Quint. Inst.Or. 8.2.21). Convincingly, he regards its prevalence as being more true for poetry than for prose. Cf. Chr. Carey, Ethos and Pathos in Bacchylides, in: I.L. Pfeijffer \& S.R. Slings (edd.), One Hundred Years of Bacchylides. Proceedings of a Colloquium held at VU Amsterdam (Amsterdam 1999) 17-30, on the same principle of the poet 
for it is by no means my intention to begrudge the author one of his narratological instruments.

"Active involvement in finding ourselves how things cohere" is all in the game, our game. Literary critics of our time have not much choice, since venturing too far outside the borders of their paradigmfor, indeed, the requirement of consistency and coherence is a paradigmatic trait-might imply the risk of depriving themselves of their raison d'être. Occasionally, however, the 'uneducated' profane would welcome some touch of reflection on the question whether they are really reading the text $e$ mente auctoris and do indeed re-evoke the meaning that the author had wished to convey, or rather impose their own late- or postmodern paradigm on the ancient literary work and thus construct a perhaps breathtakingly ingenious but nonetheless anachronistic construction of their own. ${ }^{102}$ In this-but only in this-respect, a postmodernist statement such as "the discourse of literary or art criticism is not out to recover meaning, but to create and

\footnotetext{
"inviting the audience to fill the gaps" in accordance with the statement of Theophrastos (above) "not to tell the audience everything." Cf. more generally: T.K. Hubbard, The Pindaric Mind: A Study of Logical Structure in Early Greek Poetry (Leiden 1985). Of course, Pindar is truly different from both Homer and Herodotus. As to Homer, however, Alexarchos does apply the related principle $\tau$ ò $\sigma \iota \omega \pi \omega ́ \mu \varepsilon v o v$, whereby the poet takes many things for granted, or "leaves it to his hearers to consider themselves what

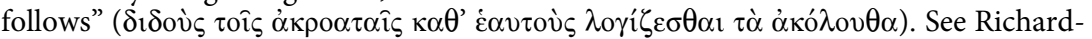
son o.c. (above n. 65), 271. However, especially in the case of Pindar, another question prompts itself: how would the audience react to all these deliberate gaps in a genre of poetry which itself was not very easy to understand to begin with? Relevant information from ancient sources is not encouraging. R.W. Wallace, Speech, Song and Text, Public and Private, in: Eder 1994, 199-217, discusses the testimonia (e.g. Ar. Av 1372: "you make even less sense then a dithyramb", and many similar complaints about the obscurity of tragic and lyric poetry) and argues concerning Aeschylus that "his texts were always unintelligible, in terms of meaning" (and cf. above Ch. I n. 228). Note that no participant of the colloquium in question uttered disagreement, but, then, all but one were historians.

${ }^{102}$ Just one frightening instance from the study of Juvenal. H.A. Mason, Is Juvenal a Classic? in: J.P. Sullivan (ed.), Critical Essays in Roman Literature: Satire (London 1963) 95, writes: "I do not see how we can hope to become literary critics of any foreign poetry without first graduating as critics of the poetry that is nearest to us. The royal road to Juvenal is through profound enjoyment of the poetry of Eliot and Pound." To be read with the trenchant criticism by K. McCabe, Was Juvenal a Structuralist? A Look at Anachronisms in Literary Criticism, GeB 33 (1986) 78-84, who concludes: "Those who read contemporary criticism must often believe that the critic himself wrote the work under discussion, or they would be hard pressed to account for the freedom of interpretation and absence of evidence so commonly discovered in much literary criticism today." Cf. next note.
} 
contest it"103 may provide a considerable, albeit momentary, respite. If pursued in this way literary criticism is indeed a relatively harmless branch of sports. The historian has no direct interest in literary fiction constructed by a modern reader from the debris of an ancient text, as long as it is acknowledged as being fiction. However, his problems begin when literary critics maintain that their readings are the ones that the author had in mind. After all one of the first tasks of the historian is precisely that: to recover what the author may have meant. It is here, then, that increasing hermeneutical sophistication hand in hand with a decreasing receptivity for the specific philosophy of life of the ancient author and his audience invites critical reflection.

In fact, students of ancient history, and historians of ancient Greek religion in particular, find themselves in a schizophrenic position. Their interests induce them to embrace the roles of both philologists and anthropologists. As a rule less versed in the sophisticated niceties of modern hermeneutics, they may not always be sufficiently aware of the fatal risk they run in assuming that a literary text should convey direct and unambiguous information on historical realities. ${ }^{104}$ In order to avoid that trap, they must become literary critics, and if they do not have the time or penchant for it, at least carefully listen to their literary colleagues and accept that they go as far as they can in 'making sense'. Yet, as anthropologists they should never forget the very first

${ }_{103}$ D. Fowler, Roman Constructions: Readings in Postmodern Latin (Oxford 2000) 107. It is just a variant of the "infinite openness of the text" and its corollary "stop making sense" proclaimed by post-modern text criticism. For surveys of the earliest post-modern experiments in classical philology see: S. Kresic, Literary Hermeneutics and Interpretation of Classical Texts (Ottawa 1981); Benjamin 1988 (also including critical contributions). For many the starting shot was given by H.-G. Gadamer, Wahrheit und Methode: Grundzüge einer philosophischen Hermeneutik (Tübingen 1960, translated as Truth and Method [London 1981]), as for instance in his lapidary summary at pp. 145-150: "a hermeneutics that regarded understanding as the reconstruction of the original would be no more than the recovery of dead meaning. (...) The essential nature of the historical spirit does not consist in the restoration of the past, but in thoughtful mediation with contemporary life." A consistent application of this hermeneutic approach can only flourish on the ashes of historical research as I have argued in Versnel 1990, $30 \mathrm{ff}$. See for a virulent, yet balanced, criticism: C.B. McCullagh, Can Our Understanding of Old Texts be Objective?, H\&T 30 (1991) 302-323. An exemplary critique on recent anachronistic (= deconstructive) reading and an equally exemplary return to viewing text and interpretation in their historical contexts: G. Ferrari, Hesiod's Mimetic Muses and the Strategies of Deconstruction, in: Benjamin 1988, 45-78.

${ }^{104}$ On which, among the great flow of relevant literature, Pelling 1997, despite my objections to certain contributions (above Ch. I n. 427; below Appendix II) is of central importance, in particular his conclusion (213-225). 
law of that discipline, which is never to impose our cosmology on that of 'the other', which would equate "making sense" with "imposing commonsense." 105 They must be continuously aware that it may be our drive towards coherence that we are imposing on the text, a drive which the archaic author-and in the episodes under discussion Herodotus is, not only in my view, following an archaic pattern-may not have dreamt of in his philosophy. This means that they should dissuade the literary critics from going farther than they reasonably can. ${ }^{106}$ Not, for instance, as far as to push their 'active involvement' vis-à-vis the author to the extent of helpfully supplementing implicit motifs such as blaming Polykrates for throwing a tiny ring and not his wife-or anything else of more girth-into the sea in order to escape

${ }_{105}$ As scorned by E. Leach, Social Anthropology (London 1982) 28. f. One of the first professional qualities a modern anthropologist is expected to acquire is, as I heard one saying: "to hear the alarm bell of suspicion ring as soon as cultural characteristics you think you perceive in your tribe betray a resemblance with those of your own culture." This overstatement is the final stage of a development that began with a renowned article by R.M. Keesing, Conventional Metaphors and Anthropological Metaphysics: The Problematic of Cultural Translation, Journal of Anthropological Research 41 (1985) 201-217. In it the author rang his alarm bell against "the dangers of over-interpretation..... (by taking) the unconnected bits and pieces (....) in what native actors do and say and to construct from them a coherent philosophy that no informants articulate themselves" (201 f.). An even more serious problem is "that the missing order supplied by the analyst may be wrong." And he illustrates this with disquieting examples. In his wake J.-P. Olivier de Sardan, La violence faite aux données, in: 'Interpréter, Sur-interpréter', Enquête: anthropologie, histoire, sociologie 3 (1996) 31-59, analyses five forms of methodical over-interpretation in anthropological research: the reduction to a single factor; the obsession with coherence, the significant inadequacy, the abusive generalization, the "trick" of hidden meaning. All these are exactly the issues at stake in the present chapter and this whole fascicle should be mandatory reading for the literary or historical hermeneutician. Cf. on the dangers of creating 'wholeness' also Ch. III n. 2.

${ }^{106} \mathrm{I}$ am, of course, willing to accept the general principle described by H.P. Grice, Logic and Conversation, in: P. Cole \& J.L. Morgan (edd.), Speech Acts (New York 1975) 41-58, that effective communication depends on the assumption on the part of the hearer, that what the speaker says makes sense, with the corollary that the audience of e.g. Pindar "ought to cling on to his belief that Pindar's text is coherent" (thus Pfeijffer 1999, 34, albeit with very sensible qualifications). One may even accept (though not unconditionally) N. Frye, Literary Criticism, in: J. Thorpe, (ed.), The Aims and Methods of Scholarship in Modern Languages and Literatures (New York 1963) 57-69, espec. 63: "The primary understanding of any work of literature has to be based on an assumption of its unity. However mistaken such an assumption may prove to be, nothing can be done unless we start with it as heuristic principle." (my italics). But this is only the beginning of the issue. One major question remaining is whether Pindar's (and Homer's and Herodotus') way of making sense or coherence is the same as ours. Cf. also P.J. Rabinowitz, Shifting Stands, Shifting Standards: Reading, Interpretation, and Literary Judgment, Arethusa 19 (1986) 115-134. 
his destiny. Admittedly an excessive, but by no means inconceivable example. ${ }^{107}$ Such an affront to the author!

Are Greeks, especially archaic Greeks, prototypical West-Europeans, as it is often assumed, implicitly or explicitly, not least by modern readers of Herodotus? Or are they 'desperately alien', 'exotic', 'the ultimate other', as it is dogmatically proclaimed in a special branch of recent scholarship, often including the very same modern readers? I have touched on this question in the Introduction and shall return to it. The answer I would like to suggest implies a new problem: the Greeks are both, ${ }^{108}$ and this is the most poignant summary of the

107 I confess that I made up the wife myself, but one will easily find a plenty of helpful readers' advice including that Polykrates should have given up his empire to save his life and well-being. References to stingy behaviour as the true origin of his destruction are launched in misguided attempts to at all costs make Polykrates guilty of his own fall. See for earlier attempts and their refutation: Versnel 1977, $22 \mathrm{ff}$. More recent suggestions: N. Marinatos, Wahl und Schicksal bei Herodot, Saeculum 33 (1984) 258-264; J.E. van der Veen, The Lord of the Ring: Narrative Technique in Herodotus' Story on Polykrates' Ring, Mnemosyne 46 (1993) 433-457; Shapiro 1996, 354, n. 33: "Instead of giving up his power (which is what is most dear of him) Polykrates gives up his ring." This interpretation imposes a Christianizing idea of guilt on a typically Greek tragic episode which derives its tragic meaning exactly from the fact that the tyrant does follow the advice and in this respect is not guilty. Where as a rule modern critics retrieve elements of moral guilt from other, quite distant, episodes of a tyrant's life (as we see it happen to Croesus in Pelling's study [below: Appendix III] and cf. below n. 115), these interpreters manage to completely ignore one of the very few direct clues ever provided by the author himself, namely that Polykrates after

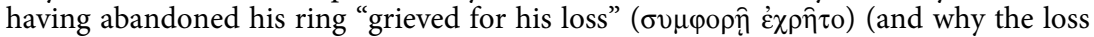
of a ring can have such an emotional impact can be found in Kurke 1999, 101-110). It is as if the author wishes to make sure that his readers, all too prone to resort to paralipsis, this time at least will not go for the wrong interpretation. But these readers know better than their author. Amasis' final conclusion is 'distragedized'. What these readers do not realize is that the traditional wide-spread tale of throwing a ring that will return is built on the notion of the inescapability of destiny, and for this very reason adopted by Herodotus.

108 One might view them as a mundus alter et idem, as Mercurius Britannicus (= Joseph Hall) called his book on imaginary expeditions to the antipodes. Or as 'distant companions' as my late colleague C.M.J. Sicking 1998, entitled his collective papers. The ancient Greeks represent 'das nächste Fremde', a term coined by U. Hölscher, to which Achim Gehrke referred me. See: U. Hölscher, Das nächste Fremde. Von Texten der griechischen Frühzeit und ihrem Reflex in der Moderne (edited by J. Latacz \& M. Kraus, Munich 1994), with at p. 278: "das vorzüglich Bildende an ihnen ist nicht sowohl ihre Klassizität und 'Normalität', sondern dass uns das Eigene dort in einer anderen Möglichkeit, ja überhaupt im Stande der Möglichkeiten begegnet." This is also the most apposite legitimation of our comparing ancient and modern societies: to detect both similarities and differences, as well as to sharpen our awareness of our own western cultural categories which may distort our perceptions of other societies. See e.g. M.I. Finley in his introduction to his The Legacy of Ancient Greece: A New Appraisal (Oxford 1981). Diffusion, Comparison, Criticism, in: K. Raaflaub 
dilemma under discussion. Unfortunately, it does very little to alleviate the desperate situation of the historian. And I am well aware that I am drawing a shamefully distorted caricature of the two positions, that the dividing lines cannot be drawn in such a rough fashion, and that the most promising work at the moment, especially on issues such as the one under discussion, is done by scholars who cannot possibly be classed exclusively in one of the categories.

Back to the texts. Feelings of uneasiness have not vanished. Doubts remain. Instead of smoothing them over we should try and make explicit what precisely is our problem with their texts. Only in this way may the differences between their and our ways of expressing things come to surface. Two of them, which have come to the fore in our earlier discussion, merit special attention. One concerns meaning, the other form. Both may hurt our sense of logic, of coherence, of consistency.

First, then, despite all ingenious, elegant and seductive attempts at overall interpretations it still is asking too much to glue together divine envy, arbitrary chance, mechanical rules of alternation, the law that the excessively fortunate will end badly, the will of the gods, predestined fate, retribution for the offence of an ancestor and personal error into one satisfactory coherent composition. Some of these options simply exclude others according to our system of logic, the basis of which-I must call to mind-we owe the Greek Aristotle. Chancestriking indiscriminately the blameless and the wicked-is incompatible with the principle of divine justice. The inescapability of fate must inescapably entail the inescapability of Croesus' error: he could never be allowed to understand the oracle correctly (and act accordingly), and hence could not be reprehended nor should he reproach himself for misinterpreting the oracle. Free choice negates predestination. ${ }^{109}$ I am not imposing modern logic on the Greeks now-as one might be thinking-for even pre-Aristotelean Greeks might allow such tensions to surface, as Theognis for instance did in his protest prayer to Zeus. It is the stuff tragedies are built of. ${ }^{110}$ My point is that this is

(ed.), Anfänge politischen Denkens in der Antike (Oldenburg 1993) 1-13. Williams 1993, 2 ff., makes it his aim to deal with both similarities and differences between the Greeks and us.

109 The discussion, triggered by Augustine and Calvinistic theologian initiatives, has never ended and can never end.

${ }_{110}$ On the problem of divine arbitrariness versus justice in tragedy see fundamentally Parker 1997, who tends to highlight the element of divine justice: "The harshness 
precisely what Herodotus in our passages does not do. He presents all options, however dissonant, as true (with the exception of Croesus' suggestions).

The second problem, closely related to the first, but so far not broached in an explicit manner in our discussion is a more formalstylistic one. The entire debate on the (lack of) consistency in the episodes under discussion would perhaps evaporate if the texts had at least betrayed a whiff of a discursive composition in which the various different explanations that are put forward are weighed, compared and discussed in an attempt to decide which is the most satisfying one, and in which the author next either renounces, or re-interprets and reconciles the other explanations. In other words: if we could have found anything resembling discursive argumentation, as we find it in philosophical, rhetorical and partly historiographical prose, sometimes also in tragedy, and elsewhere in Herodotus. ${ }^{111}$ Not, however, in the two logoi under discussion, except for Croesus' attribution of misfortune to the interference of one specific god.

On the contrary, as we saw, the multiple divergent and sometimes even contradictory suggestions in our texts are not presented

of the tragic gods is normally associated, if in complex ways, with considerations of justice; they are punishers and avengers, not forces of arbitrary cruelty." So does another stimulating study: E. Kearns, Order, Interaction, Authority. Ways of Looking at Greek Religion, in: A. Powell (ed.), The Greek World (London 1995) 511-529, with a laudable but inherently hazardous overdose of qualifications, caveats and reservations. Although she is trying as hard as possible to find a theodicy in at least some archaic authors, this is always a "qualified theodicy" (511). In Sophocles on the other hand "a mysterious, inscrutable order does indeed work in human affairs, though not necessarily to human advantage (.....) There is therefore a larger structure which includes morality, to be sure, but includes also elements which may even seem to contradict a simple moral system of 'fair' rewards and punishments. Ultimately this structure subsumes, if it does not solve, the problem of the gods' injustice" (516-517). I feel most at ease with Ch. Segal, Tragedy and Civilization: An Interpretation of Sophocles (Cambridge MA 1981) 21: "Tragedy stresses less the unifying, synthesizing capacity of a mediator than the problematical and paradoxical status of the figure who stands at the point where opposites converge. Such a figure may assume contradictory attributes simultaneously (...) Tragedy is the form of myth which explores the ultimate of mediation by accepting the contradiction between the basic polarities that human existence confronts." For Euripidean theology see: Mastronarde 2002.

${ }^{111}$ Herodotus may present a choice of possible and differentiated alternatives, sometimes concluding with his own preference, sometimes leaving the question open. For instance: 6.75-84, cf. Gould 1994, 95 ff.; Harrison 1997, espec. 101-104. In Hdt. 8.109. 3 Themistocles on the victory at Salamis says: "it is not we who have achieved this feat but the gods and heroes, who were envious that one man should be lord over

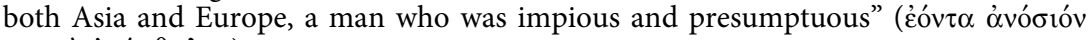

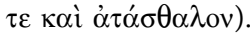


as conflicting or competing alternatives, let alone that their mutual compatibility or incompatibility is negotiated, discussed, questioned or denied. Practically without exception they are simply juxtaposed, conspicuously lacking even the faintest trace not only of helpful disjunctions such as 'or', 'yet,' or 'however', but even of conjunctions like 'and' or 'furthermore'. In other words we have here an extreme instance of asyndetic expression, invited by the (vague) connotative family resemblance of the concepts involved, but lacking comparative evaluation, distinction or equation of one with the other. As we shall discuss later, scholars of an earlier generation introduced terms such as 'paratactic style' or 'adding style', for such asyndetic accumulations. Till very recently a tendency to shun these notions may be observed in scholarly discussion, as modern literary criticism tends to prefer unity over multiplicity, assuming that these notions are irreconcilable antagonists.

Semantic discrepancy, even incongruity, among non-competitive explanatory statements on causation on the one hand; an asyndetic, paratactic fashion of presentation on the other: these are the two, in modern eyes disquieting, observations that we have found on our way. It is time to note that not every Herodotus specialist of the last decades has been equally prone to smoothing over their implications. One of the very few that took them seriously was John Gould. In several studies he paid attention to the issue, as exemplarily in Gould 1989, 78-85, where with reference to the Croesus logos, he writes (79):

Closer inspection suggests that we are not dealing with the sort of unified and structured set of ideas that we are entitled to call a theory, but rather with a set of metaphors of very different implications, (....) the different explanatory generalizations, each containing a truth, which though each pretending to give a general explanation, when juxtaposed in one context, may provide contrasting and even mutually exclusive 'solutions'. ${ }^{112}$

Borrowing a term from cultural anthropology he refers to this phenomenon as 'luxuriant multiplicity'. ${ }^{113}$ More recently Tom Harrison went over the same issue in greater detail. After a discussion of all

${ }_{112}$ With striking examples. Like Dodds, he en passant refers to these generalizing explanations as gnomai and maxims. We shall return to this below.

113 I. Lewis, Social Anthropology in Perspective (Harmondsworth 1976) 72-77, summarizing E.E. Evans-Pritchard, Witchcraft, Oracles and Magic among the Azande (Oxford 1957). 
relevant passages in Herodotus he concludes: "untidiness, inconsistency, contradiction are the glue by which Herodotus' religious beliefs hold together."114

Such verdicts, even if sustained by a thorough analysis of all relevant texts, are unpalatable to a major strand of modern Herodotus specialists. Various reviews of Harrison's book, apart from detailing justified critique of textual interpretation, betray undisguised airings of indignation at what the authors apparently feel as an affront to 'their author' and are markedly hostile in tone.

More generously, Pelling 2006, 148 n. 25 admits: "I do not wholly disagree here with the trenchant remarks with which Harrison 2000, 39-40, criticizes the drawing of fine distinctions in interpreting Solon's words, though his approach to Herodotus' narrative technique is different from mine." This is about the most elegant way to circumvent saying: "I fundamentally disagree with him." The truth is that the two scholars cannot agree since, as we will discuss in Appendix III, Pelling belongs to that trend of Herodotus interpretation which Harrison 2000,1 , has in mind when he opens his book with the phrase: "Herodotus has been growing increasingly ingenious in recent years," and p. 7: "Herodotus was possessed of so much ingenuity that he knew how not to show it." In that quality Pelling as well as any other of his like-minded colleagues can never accept the consequences of Harrison's criticism without forsaking the critic's supreme goal, namely to make sense of the ancient text in accordance with our current paradigmatic standards.

My own conclusion from these preliminary observations is that, at the very least they should make us hesitant about making an unconditional surrender to the late modern fashion of 'interpretive charity' towards our author by trying to save him at all costs from the one mortal sin in academia, lack of coherence or consistency (our consistency), and hence forcibly accommodating him under the shelter of our own modern cosmology. ${ }^{115}$ Instead, as earlier in Ch. I,

114 Harrison 1997, 112; cf. ibid. 101: "Herodotus' beliefs... cannot be reduced to any single coherent plan (...) it is precisely the inconsistencies and contradictions in his beliefs which allow them to serve as a flexible means for the explanation of events." Idem 2000, 116: "Herodotus' religious thought is simply too untidy, too responsive, too live, too far from being a simple creed or set of dogmas (....), for us to be able to describe his beliefs as 'theories'."

115 This is most conspicuously the case in the interpretations that seeks at all cost to make Polykrates and Croesus guilty of their own fall, of which I mentioned one 
I would now recommend we take to heart the maxim of Jonathan $\mathrm{Z}$. Smith: "The historian's task is to complicate, not to clarify." ${ }^{116}$ It is the most pregnant-and extravagant-expression of my conviction that smoothing over the 'irregularities' and curbing or even eliminating the paradoxes and inconsistencies in our texts is the most guaranteed method of thoroughly wiping out the very cultural signifiers that-if questioned without modern bias-may yield up a profoundly revealing message. My pursuit of complication will, I hope, further clarify my position. Here is Solon again.

\section{Solon Again}

The amount of scholarly literature on Solon's so-called Hymn to the Muses ${ }^{117}$ - created some 150 years before Herodotus' Histories-is

\footnotetext{
instance above (n. 107). The most common one in the present case is to seek the actual cause of the tyrants' downfall in their criminal, cruel and ruthless acts as described in other sections of their history. So e.g. R. Bichler, in his review of Harrison's book Klio 85 (2003) 222 ff.: "Harrison übersieht.... dass alle drei Eroberer (Kroisos, Polykrates, Xerxes) bereits durch persönliche Schuld schwer belastet die historische Bühne betreten." This is an exemplary instance of how an implied appeal to paralipsis or $\tau$ ò $\sigma \omega \pi \omega \mu \varepsilon v o v$ may go off the rail: in all three episodes Herodotus, through the mouth of his characters, cannot stop listing all kinds of (super)natural or divine kinds of causation, without even once hinting at the personal crimes, which indeed are described elsewhere. In Bichler's view, however, the reader is supposed to apply interpretive charity' here and kindly help the author by excavating what he deliberately must have left hidden. In my view the author did not refer to these testimonies of the victim's reprehensible behaviour because they were not relevant here and indeed would spoil his real message, for which he needed this bewildering multiplicity of options and viewpoints (not even including another element of actual personal guilt: haughty thoughts). Cf. Pötscher 1958, 26: "Nicht die Hybris allein bringt die Veränderung; sie kommt auch von selbst und wir suchen vergeblich, sie immer in den Kosmos unseres Denkens einzuordnen."

116 Years after his publication I asked the great 'J.Z.' whether he would still formulate it in the same way. He denied that, substituting a rather more tame revisionary text, which unconsciously I must have chosen to forget (I guess it may have been "not to simplify"). So here is another and more directly relevant utterance: "Nicht Reduktion, sondern die Komplexität, Mehrdeutigkeit und manchmal auch Sinnlosigkeit und Widersprüchlichkeit gewachsener oder von außen in neue Kontexte eingeführter Tradition zu beschreiben, ist Aufgabe des Religionshistorikers" (Chr. Auffarth, Feste als Medium antiker Religionen: Methodische Konzeptionen zur Erforschung komplexer Rituale, in: Chr. Batsch e.a. [edd.], Zwischen Krise und Alltag. Antike Religionen im Mittelmeerraum [Stuttgart 1999] 31-42, espec. 36 f.). Or, more lapidarily, in the words of the father of fractal geometry Benoît Mandelbrot: "To simplify first complexify."

117 Fr. 1 (B. Gentili \& C. Prato, Poetarum elegiacorum testimonia et fragmenta I [Leipzig 1988²]); Fr. 13 (M.L. West, Iambi et elegi Graeci ante Alexandrum cantati [Oxford 1989-1992²], whose numeration I follow). For Noussia see below n. 126.
} 
frightening. In a survey article of 1983, G. Maurach presented a very useful survey and discussion of thirty studies, including a detailed thematical analysis of the poem. ${ }^{118}$ In 1992, H.G. Nesselrath did the same for the ensuing decade, with another six articles. ${ }^{119}$ Since then, the stream of papers on the thirteenth elegy seems to have been running dry, but the poem continues to play a major role in studies of Solon's political, moral and poetical stance. ${ }^{120}$ With few exceptions studies of the elegy focus on, or at least cannot avoid, two central issues: sense and coherence. As to the first, in Maurach's view the theme of the warning against avarice and excessive wealth had won the field as being the author's central (albeit not exclusive) concern. ${ }^{121}$ This does not seem to have radically changed since. Indeed, the poem's structure is decisive on this point: its beginning and ending treat the theme of human craving for wealth and material prosperity, albeit from different perspectives.

The question of coherence however has been, still is, and no doubt will continue to be an inexhaustible source of dispute. A linear reading of the text-and in what other way than linear would one read a poem (an archaic Greek poem in particular)?-exposes the central problem. Here is a rapid survey of the successive themes of the elegy:

118 A. Spira, Solons Musenelegie, in: Gnomosyne. Menschliches Denken und Handeln in der frühgriechischen Literatur. Festschr. W. Marg zum 70. Geburtstag (Munich 1981) 177-196, provides a less comprehensive survey with a focus on earlier views on the poem's unity and purpose.

${ }_{119}$ In order not to overburden my bibliography I will refer to authors discussed in these two survey papers with names and dates as there given.

${ }^{120}$ On K. Matthiessen, Solons Musenelegie und die Entwicklung des griechischen Rechtsdenkens, Gymnasium 101 (1994) 385-407, see below n. 134. Sicking 1998 originated as "Solon's 'Muzenhymne'," Lampas 17 (1984) 290-300, which no, doubt due to the language, had largely escaped attention. Monographs containing treatments of the elegy include: R.K. Balot, Greed and Injustice in Classical Athens (Princeton 2001), Ch. 3, 'Solonian Athens' pp. 58-98, espec. 79-98, with only few references to the 13th elegy. On Lewis 2006, Ch. 5: "'Moira brings good and evil': Bios and the Failure of Dikê," see below n. 136. Important commentaries: C. Mülke, Solons politische Elegien und Iamben (Fr. 1-13; 32-37 West) (Leipzig 2002); M. Noussia, Solone. Frammenti del' opera poetica (Milano 2001), with a clear, brief introduction into the different interpretations followed by her own as elaborated in her commentary, which, at many points, I endorse. Noussia-Fantuzzi 2010 appeared when the present book was already in print.

${ }_{121}$ On the inherent paraenetic nature of the poem e.g.: Büchner 1959; Spira 1981, in symposiastic context. E. Irwin, Solon and Early Greek Poetry: The Politics of Exhortation (Cambridge 2005), despite her focus on the paraenetic aspects of Solon's poetry does not pay specific attention to Fr. 13. 
I 1-13 Good or bad wealth and the consequences.

Wealth righteously begotten I do wish to possess and good fame, for wealth given by the gods is stable. Ill-gotten wealth (through acts of hubris), on the other hand, is hounded by dike. Soon ate gets involved. ${ }^{122}$

II 14-32 The modalities of divine punishment.

Excursus on the growth of ate. Beginning as a tiny spark, it ends up as

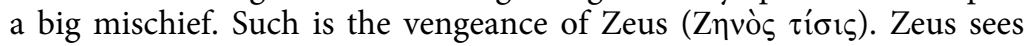
every iniquity and, never losing sight of the end ( $\tau \dot{\varepsilon} \lambda_{0} \varsigma$ ), punishes one person immediately, another after some time. Some people themselves flee and escape the $\theta \varepsilon \hat{\omega} \nu \mu o \hat{\rho} \alpha \alpha$, yet in the end it will come and innocent people ( $\alpha v \alpha i ́ \tau 101)$, their children or posterity, will pay.

III 33-70 Frustrated hope, the futility of human endeavour, the arbitrariness of fate, the instability of good and bad luck.

Human hope is vain. It is stupid to rely on high expectations. Everybody

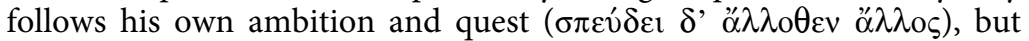
often the contrary of what one pursues happens. The results of medicine for instance are unpredictable: sometimes it works, sometimes it makes things worse.

All this is expressed in the following general observations:

1) (A prophet sees the mischief coming and the gods are witnesses, but) no ominous bird nor sacrifice can ward off what is destined to be ( $\tau \grave{\alpha}$

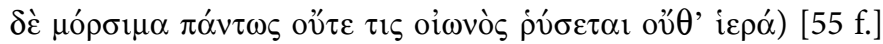

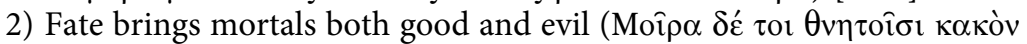


3) The gifts of the immortal gods are inescapable ( $\delta \hat{\omega} \rho \alpha \delta^{\prime}{ }^{\prime} \alpha \varphi v \kappa \tau \alpha \theta \varepsilon \hat{\omega} v$

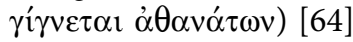

4) There is always a risk in every enterprise: nobody knows how things

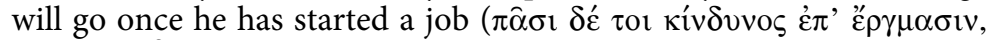

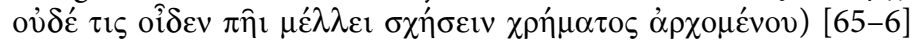

5) This section ends with the remarkable statement: "He who tries to act correctly may, through lack of providence, fall upon big and grievous ate; but the one who takes a wrong action: god may grant him good

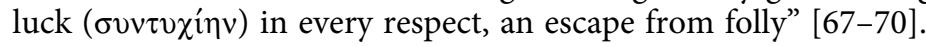

\section{71-76 Undifferentiated wealth and its consequences}

Wealth knows no limits. Whoever has property wants it doubled. Who could satiate everybody? The gods have given mortals the opportunity to make profit, from it ate comes forth. Whenever Zeus sends ate as punishment, people suffer from it, one now, another next.

122 On ate in Solon see: H. Roisman, Ate and Its Meaning in the Elegies of Solon, GB 11 (1984) 21-27. 
Divergent interpretations and assessments of the poem are on lavish display on a gliding scale between two extreme positions.

In the middle one finds a majority of scholars of different cast who all acknowledge that the poem, albeit consisting of a number of smaller subsections, ${ }^{123}$ displays two clearly distinct themes. Part I with its emphatic differentiation between good and bad wealth leads naturally to II the righteous punishment of unjust behavior. Misfortune here is regarded as a result of human guilt: "Unrecht Gut gedeiht nicht" (v. Wilamowitz). Then, at 1.33 , there is a harsh caesura, for part III is entirely devoid of moral reflection or causation. All of a sudden, both prosperity and misfortune are not the effects of human action but of superhuman principles of chance, vicissitude and luck or misfortune. No human being knows at the beginning what the outcome will be. IV finally, returns to the notion of wealth, but it is far from being a perfect circle, for this time there is no differentiation between good wealth which in part I was defined as stable, and ill-begotten wealth which was sure to attract ate and, consequently, divine punishment. This time it is wealth as such that unavoidably entails disaster due to the unlimited greed that it evokes in man. The two basic contrastiveindeed incompatible-themes in the poem, then, are the righteous divine punishment of human unjust behavior on the one hand, and the arbitrary forces of fate or chance that are beyond human influence and make the course of human life unforeseeable, on the other.

At both ends of the hermeneutic scale one finds extreme alternatives. One is the conviction that the poem lacks anything resembling transparent coherence. Its structure can be described as a chain of considerations with more or less independent status, but in which the poet was less guided by the wish to achieve a goal he set himself in advance than by the associations each subsequent idea evoked in him. Especially among scholars of an earlier generation this was seen as a typical archaic trait of language and thought. Consequently, one may find the poem being censured for its careless composition and style. Fränkel's $(1973,236)$ judgment “Solon's ideas are consistent to

${ }^{123}$ As for instance Maurach's (26) four "Handlungsstrukturen": 1) Hybris zieht dike, ate nach sich; 2) undistanzierte Erfolgsantizipation "wiegt leicht" (und ist schmerzhaften Misserfolg ausgesetzt; 3) alles Handeln ist als zukunftbezogenes unprognostifierbar (und dem uns unberechenbaren Zugriff der Moira ausgesetzt; 4) gieriges Geldraffen zieht Zeus' Vergeltung nach sich." He emphasizes as a general characteristic of the poem: "es geht darum was im Menschen vorgeht und weniger die Seite der Moira, der Götter, und Zeus also die Seite der 'Theologie'." 
a degree, but only to a degree" is clement as compared with others. ${ }^{124}$ Recently, D.E. Gerber, ${ }^{125}$ still writes: "Fr. 13 is of poorer quality (i.e. as opposed to his other fragments). Because of its lack of cohesiveness it has generated a considerable bibliography." This lack of cohesiveness has even seduced scholars to rigorously split up the poem in parts, some of which may then be ousted as non authentic. ${ }^{126}$

At the other end of the scale one finds attempts to detect unity at all costs. Here in particular the scale's 'gliding' nature comes into view: some scholars of the middle group, though acknowledging a division in the poem, cannot resist the lure of unification. Complying with what they consider the supreme task of the philological craft, ${ }^{127}$ they work miracles in their attempts to salvage their coherence from the wreck of the poem's inconsistency. This they do sometimes, just as we have seen in the discussion on the Herodotean Solon logos, with some, never with complete success. To be sure there are some obvious implicit links. The penalty executed on an innocent posterity as mentioned in line $31 \mathrm{f}$. self-evidently evokes the inference that nobody, neither the guilty nor the innocent, can be sure about his own future. As such these lines may be regarded as both the poem's pivoting point and the lifebuoy of its coherence. Also the ring composition in which the

${ }^{124} \mathrm{He}$ adds: "Anyone who looks for discrepancies, imperfect logic, and new questions provoked by his answers to the old, will find them in abundance. Solon does not construct a consistent general theory, for he is not a true philosopher." Cf. Wilamowitz 1913, 257: "Es kommt darauf an, Gedanken, die in verschiedenem Verhältnis stehen, richtig zu verbinden, während Solon sie einfach coördineert hat." The problem with Solon is: "dass die Fähigkeit zu denken der Ausdrucksfähigkeit weit voraus ist." Lattimore 1947, 161-179 descries a self-generating series of ideas with no subject: "sections are fast at one end, free at the other." So, too, but in a particular way, Van Groningen 1958, 94 ff. Cf. West 1974, 181: "a rather rambling train of thought;" Knox 1985, 148: "the structure is loose and the sequence of thought muddy: the style is careless."

125 Greek Elegic Poetry (Loeb 1999) 6.

126 Perrotta 1924; G. Puccioni, in a review of A. Masaracchia, Solone (Firenze 1958) in: AઐR 2 (1957) $117 \mathrm{ff}$. Hommel 1964 explains the harsh clash between the two sections as the result of a conflation by Stobaeus or a predecessor of two separate poems of Solon. The section of 1l. 33-76, with its traditional pessimism and belief in fate would stem from the poet's youth, the first part, with the belief in divine justice, was written by the mature Solon. Cf. below n. 134 .

${ }^{127}$ Fränkel 1955, 51: "Die verhältnismässige Unabhängigkeit der einzelnen Stoffpartikeln kann zu einer Überwältigung des schwachen und widerstandslosen Dichters durch die Fülle der vielspältigen Wirklichkeiten führen; andrerseits kann die Reihung seine Auffassung und Phantasie anregen und leiten, gerade das Gleichartige und Zusammengehörige in Darstellungsketten zu schildern, oder auch in schweifender Kühnheit die geheimen Verbindungen zwischen den verschiedenen Bereichen des Daseins aufzudecken." (my italics) 
precariousness of the craving for wealth appears both in the beginning and at the end may be a sign of a unifying strategy. ${ }^{128}$ But this does not necessarily imply a holistic preconceived composition. Coherence can also be a result of gradual shifts in the train of thought during the process of creation.

In other respects the text is less than co-operative in providing clues for a smooth and unhampered reading. ${ }^{129}$ However, this precisely constitutes the challenge which is the raison d'être of modern (prepostmodernist) literary criticism. Inspired by the opening of the poem scholars have set out to detect an underlying theme of divine justice throughout the poem, even in the second part where the theme of righteous punishment has totally evaporated to make way for a focus on human lack of insight and helplessness in a world that is ruled by arbitrary Moira. The major strategy, sometimes referred to with the term pantisis ("all [is] punishment"), amounts to redefining the human frailties in lines 33-62, such as (vain) hope and arduous striving with unforeseeable (mostly disappointing) results, as a manifestation of human hybris. By first taking them as testimonies of human short-sightedness and extravagant optimism, and next reinterpreting this as a reprehensible lack of moderation, the way is paved for the conclusion that human frailty entails divine retribution.

This approach mirrors the one we have seen in our discussion of the Herodotean episodes; in the background is the same (mistaken) conviction that in the end misfortune must be a consequence of man's own failure, ${ }^{130}$ even if the actual text is totally devoid of relevant

128 "An interpretation that does not expressly take into account these characteristics of beginning and end can hardly be correct" (Sicking 1998, 9).

${ }_{129}$ Fränkel 1973, 234 again, "For long stretches the language of the elegy is flowing and lucid; but occasionally there are difficult and obscure passages, and sometimes the connection between the parts is not plain."

${ }^{130}$ So already Reinhardt 1916, who united both punishment for unjust behaviour and retribution for natural short-sightedness, under the label 'Schuldigwerden'. Römisch 1933, 34: "Menschliches Unglück ist Folge von Fehlwissen;” Fränkel 1950, 272: “immer wollen wir zuviel (...) Nur durch Ruhe und Mässigung können wir den circulus vitiosus brechen;" Sira 1981, 189: "Solon sieht [...] jedes Verderben als Götterstrafe." Three of the six authors discussed by Nesselrath (Dalfen 1974; Eisenberger 1984; Christes 1986) follow the same strategy in that: "sie die bis zum Ende des ersten Teils über die göttliche Vergeltung entwickelten Gedanken auch auf den zweiten Teil konsequent anzuwenden versuchen (...). Menschliches Leid und menschliches Scheitern seien sozusagen die Quittung für frevlerisches Vergehen, das sich diese Menschen entweder selbst oder jedenfalls ihre Vorfahren hätten zuschulden kommen lassen" (Nesselrath 92). 
corroborative hints. ${ }^{131}$ In its most appalling excrescences this theory takes us to the extreme end of the scale: "Alles Leid ist immer gottgesandte Strafe (...) für gottgesandte Schuld” (my italics), says Müller 1956, 51, arguing that the good man who suffers bad luck is privileged because in this way he can more easily resist the enticement of success ("die Verlockung des Erfolgs"), an interpretation so absurd that its cradle must be sought in the Christian tradition of theodicy, where we find closely similar saving strategies. ${ }^{132}$ An alternative unifying strategy is to take the second part of the poem, with its warning of the futility of all human efforts, as hosting the central idea. Maurach p. 24, for instance, sees as Leitmotiv of the whole poem the distinction between "menschliches Wähnen und göttlicher Klarsicht" (human illusion versus divine clear vision), ${ }^{133}$ although the first part has not much to support to it.

It is impossible to go into all ingenious (and divergent) arguments launched to reconcile the poem's two inconsonant themes either by putting them under the umbrella of an 'all is tisis' idea or by assuming another comprehensive binding theme. Nor is it necessary. Many scholars, including Maurach and Nesselrath, have advanced strong counterarguments. No 'unitarian' can circumvent the problem raised by the sharp caesura in lines $33 \mathrm{ff}$. The one who tries to bridge this cleft by interpreting 33-66 as a perseveration of the foregoing lines by

131 Sicking 1998, 12, describes "the six examples of the human tendency to commit oneself to the goals one has in mind" some lines later as "the false certainty of people who vainly try to escape misfortune." This, however already verges on overinterpretation in clearing the way toward reprehensible human error. The text nowhere implies that they try to escape misfortune. It says only that they are trying to make some fortune. Maurach 23, hits the mark when he argues that with regard to the six types of occupation of lines 43-58, the text gives no hint of censure ("Kein Tadel hörbar;" "Keine Zeile und kein Wort in 43-70 ist eindeutig tadelnd "[24]). The general theme here is the uncertainty of the outcome, which, however is not under the regime of Zeus' righteous punishment but of arbitrary Moira (63), here identified with 'the gods' as a comprehensive notion that cannot be identified with the personal Zeus who wields justice in 17 and again in 75 . Neither is lack of 'wise measure' a central idea, least of all if explained as another cause for divine punishment.

132 See below p. 236. Pötscher 1987, too, notes that side by side with divine punishment there is also room for divine mercy ("Gnade") which may even fall upon criminals ("was für Solon entschieden zu christlich gedacht scheint," so rightly Nesselrath 93). Maurach 24 (in the wake of others) speaking on these lines, gives a decisive and indeed inexorable verdict: "An 'Schuld' ist nicht gedacht; würde man $69 \mathrm{f}$. ethisch verstehen, ergäbe sich Absurdes: der Böse wurde belohnt."

${ }_{133}$ Of course, earlier scholars already have focused on this opposition between human weakness and divine insight. More recently, Sicking 1998, 12, too, puts the contrast between man and the gods in the limelight. 
way of reflection on the consequences of the idea that the 'children pay for parents' guilt' idea, runs up against another problem. The passage that lists the examples of vain human effort has lost any connection whatsoever with the notion of divine justice. What it does offer is an independent 'philosophy of life'. Decisive, however, are the lines that conclude this passage: $63 \mathrm{f}$. and 67-70.

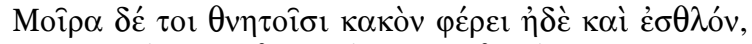

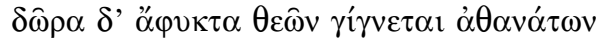

(Fate brings good and ill to mortals and the gifts of the gods are inescapable).

He who tries to act correctly may, through lack of providence, fall upon big and grievous ate, but the one who acts badly: god may grant him

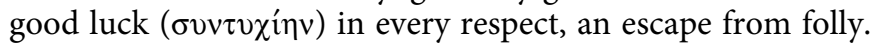

Being the conclusion of the section on the vanity of human hope and effort, these lines undeniably conform to the notion of arbitrary fate and chance that imbues this passage. As these lines defy any interpretation in a perspective of divine justice, the 'unitarians' must either ignore them or downplay their impact, or try out an explanation, which, as in the case of the grotesque solution of Müller just quoted, is bound to fail.

All this leaves us with only one alternative approach, which is both more promising and, as we will discuss later on, more in accordance with the nature of archaic poetry. That is to take into full account the poem's ongoing flow of thoughts, consistently and rigorously reading it in a strictly linear way, a course of action which many scholars embrace but which only few succeed to sustain consistently and impartially: "soon ate gets involved". Such a rigorously linear analysis will inevitably disclose the poem's dual structure, but instead of disappointment about its regrettable (hence debated) segmentation, it may yield a fresh appreciation of the gradual (or intermittent) shift in the author's train of thought. ${ }^{134}$ The two recent studies in which I found

${ }^{134}$ Following this hermeneutic principle one still may end up with one global general theme, as for instance Allen 1949 does, who sees the poem as one extended prayer for wisdom. Nesselrath, who explicitly advocates this approach, sees the second part as an expanding way of looking on human vicissitudes, which transcends the rather black-white juridical vision of the first. Yet surprisingly he ends up with the same pantisis idea that he forcefully opposed in the beginning: "Nach dieser erweiterten Betrachtungsweise macht sich der Mensch offenbar nicht nur dann schuldig, 
this approach most exemplarily represented share the idea that the second part should be seen as an 'afterthought' which indeed conceptually interferes with the first. This interpretation, however, does nothing to detract from the poem's quality. If there is unity in the poem it is a dialectical one.

Sicking 1998 sees in 11. 37-62 an elaboration of the idea that Zeus, unlike mortals, watches over the telos as contrasted with the vain optimism of mortals. He fully acknowledges that 63-70 mark a decisive change: the main contrast with the naivety of human optimism is no longer the power of the gods, who see to it that the final result will be in harmony with $\delta$ ín $(28-32)$. The conclusion to be drawn from the series of examples is that, in spite of human effort, in the last instance, it is Moira who distributes good and bad. There is a gradual shift from the idea that gods as guardians of $\delta$ í in their wielding of justice towards the statement that the outcome of everything is uncertain. The crucial lines $67-70$ imply that the fall of the one with good intentions and the good fortune of the bad may reflect the intention of the gods. This leaves us very far removed from the more straightforward confidence expressed earlier that malefactors can at best temporarily escape repayment because gods take their time. The return to the topic of wealth and its new modifications must be seen in the light of the immediate foregoing considerations. And Sicking summarizes:

The belief that being struck by ö́ $ๆ$ is to be seen as Zeus' way of exacting

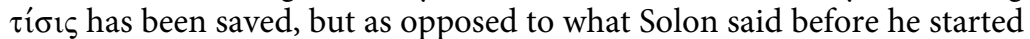
his development of the $\sigma \pi \varepsilon v \dot{\delta} \varepsilon \varepsilon \stackrel{\alpha}{\alpha} \lambda \lambda_{0} \theta \varepsilon v{ }^{\prime} \alpha \lambda \lambda_{0}$ motif, he now says that ö $\tau \eta$ may strike all.

Sicking argues for a gradual shift in the course of Solon's argument, and concludes that Solon's way of reasoning may be characterized as a kind of dialectics, reconsidering and deepening the initial idea time and again, and contrasting it with its opposite, until finally the initial belief, which, at the time, may have seemed a truism, has been shown

wenn er moralisch eindeutig schlechte Handlungen begeht, sondern auch dann, wenn er-ohne an seine Grenzen zu denken-sich mehr zutraut als er sich zutrauen dürfte." Likewise Matthiessen o.c. (above n. 120, a rejoinder to Hommel's 1964 separative approach), while recognizing the decisive change in lines $63 \mathrm{ff}$., yet in his defence of the poem's unity in its focus on divine justice smoothes over its basic import and consequences. 
to be much less obvious and more problematic than it seemed to be. ${ }^{135}$ The confident statement with which Solon started the poem is both modified by and enriched with the results of an unprejudiced observation of human behaviour - the price to be paid being a substantial part of the initial transparency and certainty.

This, to my mind, is as far as one can go in trying to detect unity in the poem. Naturally, many a single observation had already been suggested by earlier scholars. However, the stringent linear reading entailing a both merciless and constructive recognition of inconsistencies and indeed of the central inconsistency in the poem renders Sicking's interpretation refreshingly convincing. My appreciation of its approach may excuse the extensiveness of my rendition, which, naturally, I could not decently have done without first giving a review of other, less attractive, current approaches. Nor is Sicking the only one following this line of interpretation. While preserving both the sharp division and the authenticity of the poem, Lewis 2006 more recently adopted a comparable course in assessing the poem. He argues that the latter part of the elegy betrays Solon's pessimistic worldview on man as a helpless individual, at the mercy of inscrutable forces beyond his comprehension, responsibility and sphere of influence. As such it modifies the more optimistic tenor of the first part which addresses the community of the polis, seen as a cohesive whole, a "moral kosmos ordered by dikê (p. 59), as in so many other of his verses. ${ }^{136}$

Altogether, in Fr. 13 we recover in Solon's own words the very same luxurious multiplicity that guided Herodotus in the episodes we discussed earlier. Indeed, the variety of different options in the elegy closely corresponds with the Herodotean list that we have drawn above. All four categories listed there prevail in the elegy. On the one hand, there is the external factor, differentiated into three registers:

135 This interpretation can hardly be reconciled with the view that the poem is the product of a consciously conceived composition in the strict sense of that word.

136 This opposition is also clear from the composition of this interesting book. Chapter 4, "A Kosmos of Words: Archaic Logic and the Organisation of Poem 4," treats Solon's idealistic political and social ideas concerning the polis. Chapter 5 on Fr.13 with the meaningful title "'Moira brings good and evil'; Bios and the Failure of Dikê," (= 'Dike', 'Moira', 'Bios' and the Limits to Understanding in Solon, 13 [West], DIKE 3 [2000] 113-136) sketches Solon's more pessimistic views on the frailties of man as an individual mortal being. This concurs with the concession that Gerber subjoins to his negative judgment of the poem cited above: "But for all its imperfections it shows us a more reflective and philosophical Solon than we find in most of his other verses and thereby fills out a picture of the man." 
(I) universal principles, both arbitrary and predictable ones: fate, chance, instability of life, (II) the arbitrary, or at least inscrutable, intervention of a god or gods: $\theta \varepsilon \hat{\omega} v \mu$ oîp $\alpha$, and (III) a combination of these two, here not in the form of divine envy, but as Zeus' inescapable

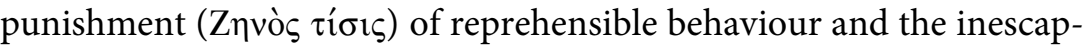
ability of ate striking the all too wealthy. On the other hand, there is (IV) the internal factor, the personal guilt of the human being, who is himself responsible for his own destruction, or has his offspring pay for his offense. Once more, too, we recognize the Homeric sequence: Zeus (as highest divine principle), Moira, Erinys, the god, ate.

It is as if the whole gamut of divergent options collected in archaic poetry and more especially in the Theognidean corpus has been digested into one poetical experiment. ${ }^{137}$ Thgn. 197-208, in particular displays such striking resemblance with Solon's elegy-linking the theme of good versus bad wealth with that of children paying for their fathers' sins-that dependency is practically certain. ${ }^{138}$

The two observations suggested by our reading of the Herodotean passages once more force themselves upon the reader and with even more vigour. The poem consists of a chain of motifs, entirely devoid of formal conjunctive or disjunctive signals or allusions. Nor does one alternative refute prior ones in a gradual ascent towards a final and decisive conclusion. The closing idea that possession of wealth entails

137 The unexpected (and worrying) theme of lines 67-70 returns in Thgn. 133-142, espec. $136 \mathrm{f}$. "Often a man who thought he was to fail succeeds, while one who thought to be successful fails." Cf. Thgn. 161-164; 661-667: "a man in penury grows quickly rich, or one who has abundant wealth loses it all within a single night; a wise man goes astray, a fool's imaginings come true; even the no-good wins respect." Cf. A. VideauDelibes, Élégie et retournements de fortune, des archaïques grecs aux poèmes tibulliens, in: D. Conso et alii (edd.), Mélanges F. Kerlouégan (Paris 1994) 651-666. For a comparison between Solon and Theognis on the issue of justice see: G. Nagy, Theognis of Megara. The Poet as Seer, Pilot, and Revenant, Arethusa 15 (1982) 109-128.

138 Thgn. 197-208: "Such wealth as comes from God by way of righteousness and free from stain, abides for ever more, but if a man acquires it wrongly (....) in the end it turns out ill; the god's design prevails. Men get misled, you see, because the Blessed ones don't punish sin upon the very act; one may pay his woeful due himself, and not leave doom suspended over dear ones, another justice never overtakes, for death too soon, uncaring, settles o'er their eyes." The latter theme returns with more clarity in 731-752 in the wish "that sinners (...) should pay the price in person, and the fathers' sins should not remain to persecute the sons; and that the bad man's sons (....) should never pay for father's trespasses." 'Dependence' does not need to have been a direct one: apparently the themes were a hot topic in the 6th century. Noussia-Fantuzzi 2010, 45-65 has a good discussion and argues that many of Theognis' ideas go back to Solon. On Thgn. 197-208 there is a thoughtful commentary (in Dutch) by E.G.P. Huijing \& M. van Raalte, Theognidea 197-208, Lampas 14 (1981) 5-16. 
pursuit of wealth and thus in itself bodes ill is not more true than the opening idea that evil wealth is worse than good wealth. Neither of the two rules out the other, yet the two do not convey identical messages. Not one idea in the poem rules out any other. The view that Fate brings mortals both good and evil is neither more nor less true than the conviction that divine punishment may fall on later generations. In short, there is a peaceful coexistence of the various options. Even if they are semantically incompatible, the syntactical juxtaposition of the different motifs suggests that they are non-contradictory. They are options but —at least in the texts under discussion—not open to choice: all of them are simultaneously available, but only operative one after the other, different expressions of a kaleidoscopic multiple representation. A melody: linear, polyphonic, fugal perhaps, but with no particular emphasis on harmony and chords.

It is time once more to turn our thoughts to what we have seen and try to reach some new line of understanding. We shall do so under a title that we borrow from our first chapter.

\section{Once More: Chaos or Order?}

Indeed, it is as if the clash of modern views concerning presence or absence of order in these literary texts has dropped us back into the debate of the first chapter, the one between the assumption of-and quest for-underlying and implicit structures-kosmos-on the one hand, and the acknowledgment of what may be seen as potential chaos in Greek religious expression on the other.

So this is the moment to venture the suggestion that especially with regard to questions of theology the early Greek way of creating order may have been in tolerating or even favouring, not in reducing, the inconsistencies that we might call chaos. The result is not necessarily 'unity in diversity' ${ }^{139}$ - which of course may occur, but is easily misappropriated as a soothing expression serving to reconfiscate their experiments for our paradigm-but unity as diversity. In other words I am suggesting that the syntactically peaceful contiguity of semantically inconsonant explanations should not necessarily be censured as

139 Cf. Padel 1992, 45: "What Homeric language has, abundantly, is 'unity in multiplicity'," an expression borrowed from N. Austin, Archery at the Dark of the Moon (Berkeley 1975) 81-107. 
chaos-non-sense, hence to be adjusted in order to save the authorbut may be appreciated as another type of order, that is their type of sense. ${ }^{140}$ Appreciated also in terms of approval, for despite its desperate implications for what we call logic, one might value this versatile, multifaceted and multiple concatenation of explanatory devices in matters of theology and philosophy of life as an honest, challenging and perhaps even aesthetically satisfying device to live by. I will try to clarify this a bit further later on, but I must now first wind up my argument and try to show that this manner of reading archaic Greek texts is not so 'wayward' after all.

\section{Paratactic multiplicity}

First, it should be pointed out that the excrescences of our late modern strain towards coherence have emerged and come of age in mid 20th century literary criticism, particularly under the influence of 'New criticism' with its ergocentric approach and especially its 'close reading', after which it was adopted and adapted by all kinds of other modern hermeneutic trends. ${ }^{141}$ As such it stands in stark contrast to the great discoveries concerning the complex nature of early Greek poetry in the first half of the century. Pride of place should be given to Hermann Fränkel with his pioneering article "Eine Stileigenheit der frühgriechischen Literatur," ${ }^{142}$ soon followed by others such as W. Aly, Formprobleme der frühen griechischen Prosa (Leipzig 1929), B.A. van Groningen, Paratactische Compositie in de oudste Grieksche Literatuur, Med. Ned. Ak. Wet. Lett. 83 (1937) 83-114, enlarged and translated as La composition littéraire archaique grecque (Verhandel. Ned. Ak. Wet. Lett. 65, no. 2 1958) as well as others, including Bowra and Verdenius. As the titles indicate the focus was very much on formal

140 Fränkel 1955, 95 on Xenophanes: “Offenbar sehen diese Menschen, wo es irgend angeht, das Allgemeine unter der Gestalt vieler Einzelwirklichkeiten.”

141 "Very little has happened in American criticism since the innovative works of New Criticism," wrote one fellow of "the hermeneutical mafia of Yale" (thus W.H. Pritchard, The Hermeneutical Mafia or, After Strange Gods at Yale, Hudson Review 28 [1975-6] 601-610), P.A.M. De Man, Allegories of Reading: Figural Language in Rousseau, Nietzsche, Rilke and Proust (New Haven 1979) 4, and "none of the techniques of description and interpretation evolved beyond the techniques of close reading established in the thirties and the forties." See: F. Lentricchia, After the New Criticism (Chicago-Cambridge 1980); D. Garrick, Praising It New: The best of the New Criticism (Athens Ohio 2008). For the ensuing post-modern trend see above n. 103.

${ }^{142}$ Nachr. Gött. Gel. Ges. 1924 I, 63-103; II, 105-127 = Fränkel 1955, 40-96. 
literary aspects, style and composition, although there were also exceptions, as for instance B.E. Perry, whose article with the telling, though not very poetic, title "The Early Greek Capacity for Viewing Things Separately" (Perry 1937) seems to be forgotten nowadays. Undeservedly so.

The fundamental discovery, then, was that archaic literature is marked by a paratactic, 'adding' or 'agglutinating' diction, entailing such qualities as abundance ( $\pi$ oikı $\left.\lambda i^{\prime} \alpha\right)$, autonomy and predominance of separate parts, their functional equality, the linking of disparate and not seldom contradictory or incompatible parts and the (apparent?) lack of a uniting and binding central concept or theme. Fränkel 1955, 50: "einen Zwang zur Konsequenz gibt es nicht. Jedes Glied der Rede wird so bald wie möglich zu freier Selbständigkeit und zu voller Geltung erhoben." ${ }^{143}$ Indeed:

Paratactical arrangement often implied a minimum of cause and effect (...) or other kinds of inner coherence. Authors (....) concentrate their artistic efforts more upon the episode per se than upon the connection between one episode and another, or upon the effect of the sum total of episodes. ${ }^{144}$

So, according to scholars of this earlier generation, if there is a unity, it is one of parataxis not of a hypotactically constructed organic whole. In other words, if there is a whole, it has the nature of a 'dossier'. Nor

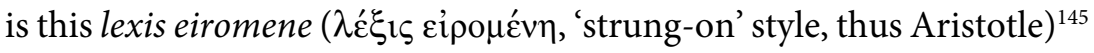
restricted to poetical expression. On the contrary, in the period in which the most extravagant agglutinatory devices tend to decrease and vanish in poetry, they are a central characteristic of the Ionian philosophical and scientific products, being:

${ }^{143}$ One of the consequences is that, according to Van Groningen, early Greek compositions often seem to lack what we would call an end, or rather a completion. The author stops, but in such a manner that he can continue any moment: he is never ready, and the work is never finished (in which much against my intention not a few of my own students tended to imitate them). The work seems to be part of a larger whole, one of the most irritating consequences being that the words $\gamma \alpha \dot{\alpha} \rho$ or $\alpha \lambda \lambda \alpha^{\prime}$ do not always refer to the preceding text, but seem to remind us that the poem is part of a larger comprehensive-but not explicit-whole.

${ }_{144}$ Perry 1937, 418. Cf. ibid. 404: "The capacity for contemplating only one thing or one aspect of a thing or person at one time, purely for its own interest and without regard to the ulterior implications or associations that an early Greek narrator might indeed be concerned about, but often is not, and that a modern person with his more schematic habits of mind would almost inevitably bring in."

${ }^{145}$ See on this term and its context Bakker 1997, 36-39. 
of a gnomic kind, characterized by axiomatic statements loosely connected, expressive words, antithesis, assonance, and an accumulation of words and expressions of a similar meaning. ${ }^{146}$

"Dichtung und Philosophie," being the title of Fränkel's chef d'oeuvre, it did not last long before the triumph of parataxis over hypotaxis was detected in thought as well as in language. Bruno Snell's book "Die Entdeckung des Geistes" 1948 [1981], a collection of articles published between 1929 and 1947, definitely raised the discussion from the level of literary phenomena to that of concept, representation and thought. Snell influenced Dodds (1951), influenced Fränkel in his later work (1973) - “in fact he influenced everybody" - thus Ruth Padel in her provocative book "In and Out of the Mind," a radically critical and highly sophisticated updating of Snell's main theses. She, too, takes her departure from the basic difference between modern and archaic Greek cosmologies: "From the start, multiplicity is a core condition of consciousness, as of religion, in Greek thought." ${ }^{147}$

Now why do we or some or most of us, modern readers, feel embarrassed by these discoveries of a former generation to such a degree that appreciative references to them-as I found out-may disqualify a scholar as a scholar? Why are these observations almost completely relegated from the discourse of modern literary criticism? ${ }^{148}$ The simplest-and decisive-answer of course would be that they have been proven wrong. It is obvious that in the flush of their discoveries scholars may have overplayed their hand in some respects, most

${ }^{146}$ H. Thesleff, Scientific and Technical Style in Early Greek Prose, Arktos 4 (1966) 89-113, espec. 90. Cf. already Fränkel 1955, 87: "Die Prosa, deren sich die Männer der Wissenschaft bedienen, zeigt den in der Poesie fast überwundenen reihenden Stil in schärfster Ausprägung." This partly contradicts Pfeijffer's 1999, 28, assumption that "the association of implicitness with the archaic age may be due to the fact that hardly any prose from that period survives," implying that this early prose would not have had such characteristics.

${ }^{147}$ She focusses here on a new and original issue, namely the highly complicated even inconsistent-and in her view sorely misunderstood-duplicity or multiplicity of the Greek representation of what she calls "innards."

148 A perusal of L'Année philologique of the last decades shows how much work has been done lately on the social setting of lyrical poetry, on its performative functions, on the development of the lyrical ego, on the distinction or non-distinction of personal and choral lyric, and how thoroughly, on the other hand, the issues that fascinated scholars more than half a century ago have left the scene. It was only recently that I was referred to a brief, clear and balanced treatment of exactly this question and a historical description which concurs with mine in Slings 2000, for which see below p. $227 \mathrm{f}$. 
conspicuously so in the case of Bruno Snell, as we have known for a long time, but-in case we might have forgotten-were reminded by Bernard Williams in his Sather lectures. ${ }^{149}$

Yet this is true only for a section of the material studied and scholars of different disciplines and interests still adhere to and elaborate on the early twenty century findings. Oudemans \& Lardinois 1987 for instance draw our attention to the differences between modern and archaic (Greek) cosmologies, which they label 'separative' and 'interconnected' respectively:

A separative cosmology defines and creates unity through the exclusion of paradox and coincidentia oppositorum, thus creating unity by reducing multiplicity, whereas an interconnected cosmology is defined by multiplicity weaving diversity into a texture of implicit connections, at the expense of clearness and distinctness. ${ }^{150}$

All this is exactly what, earlier in this chapter, I called asyndetic multiplicity.

I suggest that at least two factors are involved in the general repugnance at, and near complete suppression of, these old theories. One is again best illustrated by Snell. In his work a penchant, already visible but not nearly so explicit in his predecessors, became virulent: it is an addiction of sorts to the notion of 'not yet'. Homer was 'not yet' able to understand or isolate psychic processes as psychic processes, consequently he did 'not yet' have the appropriate words for them. Homer could 'not yet' describe a body as an organic whole. I count the term 'not yet' and its analoga no fewer than eight times in the Introduction and the first, most influential, chapter, on Homer's view of man, of the English version of the book, including an ample defense of the use of this notion on pages $15 \mathrm{f}$. In my view, here is the first main

149 Williams 1993, 21-26. A survey of studies criticising Snell's point of view in: R.P. Martin, The Language of Heroes: Speech and Performance in the Iliad (Ithaca NY 1989) 98. The most thorough and fundamental critique appeared a year later: A. Schmitt, Selbständigkeit und Abhängigkeit menschlichen Handelns bei Homer: Hermeneutische Untersuchungen zur Psychologie Homers (Abh. Akad. Wiss. Mainz. Geist.-Sozialwiss. Kl. 1990 no. 5).

${ }_{150}$ In the field of discourse and reasoning, K. Peng \& R.E. Nisbett, Culture, Dialectics, and Reasoning about Contradiction (Knoxville 1989) oppose two cultural strategies. The Chinese ways of dealing with (seeming) contradictions results in a dialectical or compromise approach, retaining basic elements of opposing perspectives by seeking a 'middle way'. European-American ways, deriving from "a lay version of Aristoteles' logic," result in a differentiation model that polarizes contradictory perspectives in an effort to determine which fact or position is correct. Cf. more generally Lloyd 1990. 
cause of modern reticence. 'Not yet' inevitably implies a suggestion of primitivism. As modern literary theory had enthroned coherence as its most lauded principle, the qualification 'not yet' could not be accepted without degrading our (early) Greeks to the level of primitives. 'Not yet' and 'primitive' are precisely the two words that cannot be decently used anymore. ${ }^{151}$

A second problem that heavily encumbers the discussion is a question that I once saw phrased in the unsurpassably clear title of an article by the philosopher R. Foley: "Is it possible to Have Contradictory Beliefs?" 152 His arguments, not unexpectedly, are in favour of the answer 'no' and provide a perfect illustration of the gulf that yawns between (some) philosophical and logical disciplines on the one hand, ordaining that this cannot be-and (some) psychological and cultural studies which simply thrive on this inconsistency. Sophisticated psychological strategies are being launched day and night in order to allow us to live with and simultaneously believe in two contrasting realities. Theories of cognitive dissonance are revealing on that point. ${ }^{153}$ Hence one problem is that (a particular branch of) philosophy and logic cannot allow what psychology reveals as ubiquitously existent. Another problem, specifically haunting our study, is that scholarship, including classical scholarship, when dealing with their literary objects of study, has to comply with a scholarly discourse that is dictated by the rules of our paradigm. And a third is that classicists, even if aware of the dubious grade of consistency in our own world of thought, pace Dodds' The Greeks and the Irrational would never accept that their ancient authors might be as irrational as their modern observers. We can see all three principles at work in the debate on polytheistic complexities in Appendix II, as well as previously in the present chapter.

Let us admit it. We simply are not in a position anymore to weigh without prejudice the following statement on the quick succession of

151 Bakker 1997, 41: "The notion of parataxis frequently and typically conveys qualities such as primitive or crude."

${ }_{152}$ R. Foley, Is it possible to Have Contradictory Beliefs? Midwest Studies in Philosophy 10 (1986) 327-355.

${ }_{153}$ Besides the works on cognitive dissonance discussed and applied in Versnel 1990 Introduction above, more general theories of cognitive consistency are relevant on the issue that human behaviour obeys an 'internal logic', or 'psycho-logic' rather than formal logic. See above n. 50. and Ch. III. n. 62. 
Pindar's metaphors by one of the great specialists of more than a century ago, B.L. Gildersleeve, ${ }^{154}$

In such passages the absence of conjunctions is sufficient to show that no connection was aimed at, and it is the fault of the reader if he chooses to complain of an incongruous blending of things that are left apart.

We cannot and we do not want to, because we are imprisoned in our paradigm of neat coherence, unity, and consistency. And we are so constrained that we spurn even as much as a consideration that (archaic) Greeks, when reflecting on the great vicissitudes of life, might have viewed things differently. For instance, in that they did not strive after an unambiguous unity, but contented themselves with "a pictorial whole of interconnected nodes" (Oudemans \& Lardinois 1987, 49).

So far for the moment our discussion of the paratactic and asyndetic way of listing statements that, though often contradictory, nonetheless all claimed to represent a truth. The question remains where ancient authors found these reliable pieces of wisdom.

\section{2. 'Gnomologisches Wissen'}

During a holiday in Greece I discussed a young girl's death by drowning with the owner of the local tavern who like me had witnessed the event. I asked her if there was a 'theological' explanation for this terrible tragedy. In an avalanche of words she explained that this was a punishment by God, that it was the will of God, that it was written

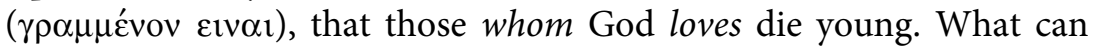

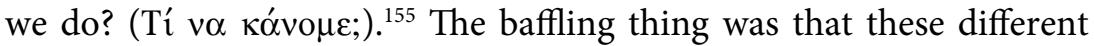
explanations-multiple, different and in my view partly discordantwere presented not as discursive alternatives open for discussion or rational choice, but in an asyndetic chain of assertions. When, later, I recounted the whole event to Greek friends who had read their classics and asked what the difference might be between 'it is the will of God' and 'it is written', they first explained to me that $\tau$ o $\gamma \rho \alpha \mu \mu \varepsilon$ vov

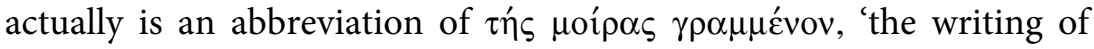
fate'-which I knew-, and next that there is no difference-which

\footnotetext{
154 Pindar, The Olympian and Pythian Odes (New York $1890^{2}$ ) xliv.

${ }^{155}$ Next day, the local physician, wishing to show off his metropolitan disdain for such rustic tokens of superstition, expressed as his view that the father-for fear of being accused of incest-must have been involved in the death of the child.
} 
I did not. When I, a renegade Calvinist, in defiance of Herzfeld's instructions (above p. 173, not known to me at the time) insisted that the (arbitrary) will of god, the punishment by god, and the writings of the Fates, could hardly be one and the same thing, they reluctantly admitted that God in some way or other must be a higher authority than fate, ${ }^{156}$ but that it was impossible for them to make a clear distinc-

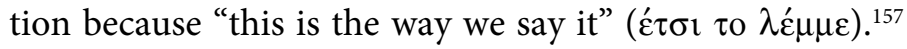

After consulting some literature on modern Greek representations of Death, Fate, and God, I understood my error. An expert in this field, R.A. Georges, ${ }^{158}$ shows how the Fates, Lady Luck, God, to grammenon, and Envy, albeit different characters, may play completely identical roles in one story or radically opposed ones in different tales. He concludes:

arbitrarily selected recorded stories from Greeks stressing fatalistic themes frequently present concepts that are not only inconsistent, but even contradictory

of which he gives astonishing examples. ${ }^{159}$ This calls to mind that in cases of 'blame attribution' and 'pleas for excuse', according to J.L. Austin 1971 the acceptability of responses to disaster and references to external causes of error is not primarily dependent upon their logical persuasiveness but first and foremost on their embedding in cultural tradition. Their undisputed place in current idiom causes them to be

${ }^{156}$ Herzfeld 1982, 657 discusses the lack of clear attributes of the fates-as opposed to those of God or the Saints-among Greek villagers. "Verbal accounts are minimally descriptive, (...) and the role of God in directing the activities of fates seems to deprive them of an autonomous identity."

${ }_{157}$ Cf. Dodds 1951, 6: "Moira, I think, is brought in because people spoke of any unaccountable personal disaster as part of their 'portion' or 'lot', meaning simply that they cannot understand why it happened, but since it has happened, evidently, "it had to be." People still speak in that way, more especially of death, for which $\mu$ îp $\alpha$ has in fact become a synonym in modern Greek, like uópos in classical Greek."

158 R.A. Georges, Conceptions of Fate in Stories Told by Greeks, in: R.M. Dorson (ed.), Folklore in the Modern World (Paris 1978) 301-319, with earlier literature at p. 308, n. 3. Cf. Eitrem, art. Moira RE 1932, col. 2495 ff. with literature on the continuity of concepts of Fate etc. in modern Greece.

159 "The fates of human beings, once determined, are often characterized as irrevocable, but they are also frequently depicted as alterable or even completely reversible, usually as a result of face-by-face interactions between mortals and the controllers of their destinies. Similarly, the extrahuman forces characterized in stories may be described as either accessible or inaccessible to human beings, sympathetic or unsympathetic to people's earthly plights, able or unable to offer advice or to alter human fortunes" (p. 308 f.). 
accepted without obliging the language user to judge the ultimately irreducible issue of their truthfulness. This, in turn, fosters accumulation and variation and protects the user against the consciousness of inconsistency. Herzfeld 1982, 646: "there is no reason why a person should not claim that 'something was an accident' while simultaneously attributing other actions to 'fate' or some other cosmological force" (Herzfeld's italics). We have seen that this need not even be 'other actions' but that it works even for the same.

Here it is less easy than in the first chapter to doubt or deny a historical trait d'union between ancient and modern Greek representations of, in the present case, the forces that steer our destiny. ${ }^{160}$ But it is not essential for my argument; what I am interested in is not the matter of cultural tradition or continuity. Also in other cultures the Christian God, once released from the theologian's protectorate, may be alternately conceived of as powerless against the Fates ${ }^{161}$ or identified with Luck. ${ }^{162}$ It suffices to have shown that human beings belonging to modern cultures are quite capable of uniting contradictory ideas about supernatural causation, and of listing them in ways that are practically identical with those of archaic Greek authors.

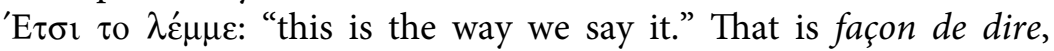
'our way of speaking', speaking in maxim or proverb, in ancient Greek gnome ${ }^{163}$ So here we are back at Dodds' casual remark, which I recommended for serious consideration earlier (p. 175). And we may now also complete Gould's view of the Herodotean "different explanatory generalizations, each containing a truth" (above p. 199) with his further remark (ibid. 81):

Herodotus' audience would have recognized his generalizations as gnomai (.....) a summing up of human experience (....). What the proverb

${ }^{160}$ In fact there is nothing against the idea of a cultural heritage of such expressions of folk wisdom and here I feel myself backed up by K.J. Dover, JHS 103 (1983) 48.

${ }_{161}$ G.A. Megas, ARW 30 (1933) 3; R.W. Brednick, Volkserzählungen und Volksglaube von den Schicksalsfrauen (FF Communications 193, Helsinki 1964) $31 \mathrm{ff}$.

162 Banfield 1958, $107 \mathrm{ff}$. as quoted above n. 44.

${ }_{163}$ Greek gnomai are not exactly the same as proverbs. See: K. Rupprecht, 'Paroimí $\alpha$ ' and Paroimiographoi, RE 18 (1949) 1707-1778; J.F. Kindstrand, The Greek Concept of Proverbs, Eranos 7 (1978) 71-85; Russo 1997. However, I feel comforted by a great expert in the field, A. Lardinois 1997, 214: "but they can be effectively studied in the same way." 
does not do, nor will it be supposed by its hearers to do, is require all subsequent experience to bear it out."164

Indeed archaic diction concerning fate and the gods is to a very large extent gnomic. So it may be expedient to expand our explorations a bit further into what, by way of variation on a concept created by Max Weber, namely 'nomologisches Wissen', ${ }^{165}$ I would propose to call 'gnomologisches Wissen', ${ }^{166}$ which moreover has the advantage of having a basis in ancient Greek lexicography. I mean the total supply of folk wisdom as stored in the treasure-house of maxims and proverbs. ${ }^{167}$ In so doing we find support in Aristotle, himself one of the first collectors of gnomai, who (Rhet. 1394a21) discusses the issue of $\gamma v \omega \mu$ о $о \gamma \varepsilon i v$, 'to speak in maxims' and at another place even is said

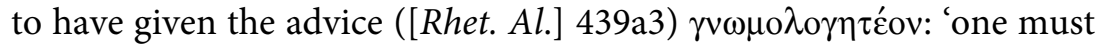
speak in maxims', since "people are pleased when they hear things said in general terms, which they happen to have grasped before in the particular case" (Rhet. 1395b5-6). Indeed, archaic Greek culture, like many other predominantly oral cultures, lived by maxims, gnomai, as their late offspring did and do. ${ }^{168}$

164 Elaborating on this at p. $81 \mathrm{f}$. Gould's ideas are vigorously endorsed and revealingly elaborated on by Harrison 2000, 9 f. and 39 f., with whose discussion I am in full agreement.

165 M. Weber, Gesammelte Aufsätze zur Wissenschaftslehre (Tübingen 1968) 192, meaning the shared awareness of traditional legal and ethological conventions within one community, and productively applied by Christian Meyer to ancient Athens.

166 Cf. G. von Rad, Theologie des alten Testaments I (Münich 1966 ${ }^{5}$ ) 434 f. (a reference that I owe to Mr. Fokke Plat), who uses en passant the terminology 'gnomische Apperzeption' and 'empirisch-gnomische Weisheit'. For the theory behind it he leans heavily on Jolles 1930, whose study is still to be recommended.

167 And ainoi, and fables. On the relationship of fables and proverbs see: P. Carnes, Proverbia in Fabula (Bern 1988); G.-J. van Dijk, Ainoi, Logoi, Mythoi: Fables in Archaic, Classical, and Hellenistic Greek Literature. With a Study of the Theory and Terminology of the Genre (Leiden 1997). On ancient gnomologies: K. Horna, Gnome, Gnomendichtung, Gnomologies, RE Suppl. 6 (1935) 74-90. More recent titles in Lardinois 1997, 213 n. 1; W. Slater, Gnomology and Criticsm, GRBS 41 (2001) 99-121, espec. 99 n. 2.

168 Lardinois, in his unpublished dissertation (see below) found more than 1200 gnomai in the works of the archaic Greek poets. See also the collection of Ahrens 1936 and more generally: Russo 1997, 49-64. For modern Greece see the full collection by P. Karagiorgos, Greek and English Proverbs (Athens 2000) with a history of the traditional elements in his Introduction. On the complications of defining the notion 'oral' see below n. 185. Aristotle's predilection for the maxim rests on the grounds that it displays the speaker's ethos, a view that only makes sense within a context of accepted values. In this respect the maxim is related to the rhetorical topos of the enthymeme: Kirwan 1990, 126 f. 
In the first half of the 20th century, with an emphasis in the thirties, an interest in proverbial expression developed in the studies of ethnology and folklore, which also found a reflection in Greek studies. ${ }^{169}$ One of its lasting results was the insight that maxims and proverbs are inherently and inevitably mutually contradictory. ${ }^{170}$

After this first bloom it is, in the words of Lardinois 1997, 213 "surprising how little attention they (i.e. gnomai, proverbs) have received in recent scholarship. (....) All comprehensive studies of the Greek $\gamma v \omega ́ \mu \eta$, or wisdom saying, date from before the Second World War." That is: among students of Greek culture, whose supposed reservations are suggestively intimated in what Slater o.c. (above n. 167, p. 100) says about gnomai:

It was largely unquestioned wisdom, even if it did not stand up to rigorous examination and was often contradictory. Systematic morality is something for philosophers not ordinary mortals, and there has accordingly always been a strong tradition of caution verging on contempt for unsystematic and tedious moralizing maxims. (....) Perhaps in modern times the intellectualist attitude has been more apparent in scholarship.......

In the meantime, however, the discipline of ethno- and sociolinguistics witnessed the rise of a spate of new studies since the 1960s. ${ }^{171}$ Their central interest is focused on the proverb's context, in particular its social and linguistic embedding. The meaning of proverbs is to a large extent dependent on the particular context in which they are used. ${ }^{172}$

169 See for a survey of Greek titles: Lardinois 1997, 213 n. 2; 2001, 93 n. 2.

170 Von Rad 1966, 435, following Jolles 1931, 156: "Es ist ein leichtes, Sprüche einander zu konfrontieren, die keineswegs übereinstimmen, ja die einander gelegentlich geradezu widersprechen." G. Permiakov, From Proverb to Folk-Tale. Notes on the General Theory of Cliché (Moscow 1979) 173: "Proverbs are signs of situations which are infinitely varied, and include many that are directly opposite in character. Herein lies the secret of the long-noted but still largely unexplained mutual contradictoriness of proverbial sayings and of the logical system of proverbs in general. It is the logic of common sense." Cf. Mieder \& Dundes 1981. Till very recently, this has largely gone unnoticed or, if noticed at all, remained undervalued in classical studies.

${ }^{171}$ See for a detailed bibliography: W. Mieder, International Proverb Scholarship: An Annotated Bibliography (New York 1982); idem, International Proverb Scholarship: An Annotated Bibliograph. Supplement (New York 1990). There is a special journal: Proverbium.

${ }_{172}$ Lardinois, 1997, 221, gives the bibliography on this particular aspect of the new proverb research. See especially: Mieder \& Dundes 1981, and cf. Shapiro 2000, 94-95. In this respect gnomai belong to the wider category of the 'cultural model', a concept introduced by D. Holland \& N. Quinn (edd.), Cultural Models in Language and Thought (Cambridge 1987), and which they define as a narrative, prototypical, schematic, and 
After a period of silence, only interrupted by casual observations of Einzelgänger such as Dodds and Gould as cited above, more recently classicists have accepted the challenge and responded to the newer insights in the socio-linguistic discipline. A. Lardinois produced the only, but still unpublished, monograph so far with his Princeton dissertation Wisdom in Context: The Use of Gnomic Statements in Archaic Greek Poetry (1995), revised parts of which appeared as Lardinois 1997, 2000, 2001. ${ }^{173}$ They are fundamental for an appreciation of the new 'contextual' approach of the gnome. His and others' recent studies demonstrate that a proverb may have different meanings according to the situation of the speaker, ${ }^{174}$ that proverbs may vary according to their addressees, that literary characters may be characterized by their preference for one of the different types of addressee, ${ }^{175}$ and that they may be characterized by being eager or reluctant to use proverbs. ${ }^{176}$ In all these ways, very much including their role in creating ambiguity, proverbs are now widely applied as tools of the literary critic in bringing to light the literary skills of their author. ${ }^{177}$

simplified form of social knowledge, available to interpret events. Especially relevant to our present topic is their stressing of the simultaneity of a variety of cultural models (pp. 6-8). At p. 10 they claim: "That there is no coherent cultural system of knowledge, only an array of different culturally shared schematizations formulated for the performance of particular cognitive tasks, accounts for the co-existence of conflicting cultural models encountered in many domains of existence."

${ }^{173}$ I am grateful to the author for giving me the opportunity to consult this impressive work. Some aspects of the new contextual approach had already been fruitfully applied for Greek literature by e.g. J. Russo, The Poetics of the Ancient Greek Proverb, Journal of Folklore Research 20 (1983) 121-130, and Y.Z. Tzifopoulos, Proverbs in Menander's Dyskolos: The Rhetoric of Popular Wisdom, Mnemosyne 48 (1995) 169-177. Older literature in: H.A. Gärtner, 'Gnome' in: NP 4 (1998) 1108-1116.

${ }_{174}$ See Chapter V p. 425 with n. 154.

175 Lardinois 2000 demonstrates the usefulness of the distinction (made by Peter Seitel in a string of studies, including: Proverbs: A Social Use of Metaphor, in: Mieder \& Dundes 1981, 122-139) in their applicability to the speaker himself (first person), the addressee (second person), or a more general audience, not necessarily present (third person). The same proverb can be used in all three different applications. Lardinois shows that Achilles, Nestor and Odysseus are characterized by addressing different addressees and adapting their choice of proverbs: Achilleus mainly 'first person', Nestor mostly 'second person'. Agamemnon is not discussed.

${ }^{176}$ Y.Z. Tzifopoulos, Hermes and Apollo at Onchestos in the Homeric Hymn to Hermes: The Poetics and Performance of Proverbial Communication, Mnemosyne 53 (2000) 148-163.

${ }^{177}$ Hence also a revived interest in individual authors' application of gnomai in their works. Besides Lardinois 1997, 2000 (Iliad); Tzifopoulos oo.cc (above n. 173 (Menander), n. 176 (Hymn to Hermes); M.S. Funghi (ed.), Aspetti di letteratura gnomica nel mondo antico (Florence 2003-4); J. Stenger, Poetische Argumentation. 
The reason for presenting this account of the new wave in proverb research, unknown to me while writing the bulk of the present chapter, is the need of testing whether it affects the interpretation of the texts, especially those of Herodotus and Solon, that we have discussed. Are the 'proverbial' explanations that we have discussed more than a reflection of "the continued operation and influence of traditional folk wisdom," as Lang has it and as I have accepted in our earlier discussion? ${ }^{178}$ Here we can call in the aid of Shapiro 2000, on "Proverbial Wisdom in Herodotus." Largely based on the survey by Lang 1984, 58-67, her collection counts eighty-six gnomai in Herodotus. She focuses on Herodotus' use of contradictory proverbs used as opposing points of view in verbal duels and finds that one side always wins. The reader thus perceives that one view of events was more accurate than the other. Unfortunately, none of Amasis' and Solon's expressions of proverbial wisdom, though adopted in her collection, figures in her discussion. Understandably too, since they do not represent one side of a verbal duel. Hence, Shapiro allows these gnomai to be taken as performing the accepted conventional function of proverbs: "they have an explanatory function: by applying a widely accepted truth to a particular situation and, in most cases, to recommend a course of action as well." While contradictory proverbs in verbal duels serve to support opposing points of view, "outside of verbal duels, they may apply to different contexts or encourage deliberation about a particular situation" (95). That is inter alia indeed what they do in our passages.

Die Funktion der Gnomik in den Epinikien des Bakchylides (Berlin-New York 2004); A.P.M.H. Lardinois, The Polysemy of Gnomic Expressions and Ajax' Deception Speech, in: I.J.F. de Jong \& A. Rijksbaron (edd.), Sophocles and the Greek Language: Aspects of Diction, Syntax, and Pragmatics (Leiden 2005) 213-223. R.P. Martin, Gnomes in Poems: Wisdom Performance on the Athenian Stage, (Princeton/Stanford Working Papers in Classics 2005), forthcoming in the Festschrift for John Papademetriou, contributes a particularly insightful introduction to the application of ethnographically informed folklore studies elaborating on his thesis that Homeric epic preserves stylized performances of social speech genres as in The Language of Heroes: Speech and Performance in the Iliad (Ithaca 1989). He applies these findings to 5th c. dramatists and Thucydides. Recently: E. Lelli, Volpe e leone. Il proverbio nella poesia greca (Alceo, Cratino, Callimaco) (Roma 2006); H. Boeke, The Value of Victory in Pindar's Odes: Gnomai, Cosmology and the Role of the Poet (Mnemosyne Supp. 285, Leiden 2007), with in Ch. 2, another introduction into and ample use of modern scholarship on the proverb. Cf. also C. Tsagalis, Inscribing Sorrow: Fourth-Century Attic Funerary Epigrams (Berlin 2007) Ch. 1 (9-61): "The Use of Gnomic Expressions."

${ }_{178}$ Lang 1984, 65, elsewhere (52), however, stating that some of them are "basic to Herodotus' (...) historical interpretation." 
There might have been an opportunity to read contradictory proverbs in(to) the Solon-Croesus story. For instance by recognizing in Apollo's 'hereditary guilt' argument a proverbial wisdom, which it no doubt is. In that case we would indeed have a couple of contradictory enunciations in Solon's proverbial wisdom sayings on the one hand and those of Apollo on the other, but not applied in a verbal duel. Either of them represents a truth and Herodotus leaves it at that. Divergent as they may be, they have one thing in common: they are all quite appropriate and conform with what is going to happen or has happened. Neither ousts the other. There is no winner for there is no competition. The author could do that because all of them belong to the category of philosophical orientation representing elemental forces such as fate, god, nature, questions of life and death. ${ }^{179}$ In Shapiro's discussion 'duels' between two proverbs of this kind are conspicuously absent. The duels are almost always between gnomai of a second category, the one concerning the nature and obligations of human relationships, such as family, fellow citizens and enemies, as well as views on human nature as it reveals itself in a social context. ${ }^{180}$ In sum, the new approaches in proverb research are welcome and important. However, they do not affect our earlier insight into the function of proverbial wisdom in our texts, namely to render experience intelligible or acceptable. ${ }^{181}$

179 I am here using the classification introduced by Boeke o.c. (above n. 177), Ch. 3 .

180 Duels between proverbs belonging to the two different categories are exceptional All this is also relevant to Pelling 2006, $143 \mathrm{n}$. 7, who betrays a touch of annoyance about Gould's emphasis on the undeniable prevalence of proverbs in the SolonCroesus logos: "Nor does it reduce the significance of the passage to observe that much of Solon's moralizing is conventional wisdom, a series of proverbs which are thrown at experience and may not always match up to its complexity." Hence he calls like-minded colleagues to assistance against Gould, including one who suggests: "that Herodotus' narrative could be seen to be in competition with proverbs" (italics in the original). Accordingly, like Shapiro, Pelling himself is more interested in "the unexpected turn" that proverbs may take than in their conventional task to render experience intelligible or acceptable. He takes to witness Shapiro's treatment of the Gyges and Candaules passage 1.8, where one finds no fewer than three proverbs about which he concludes that (145): "if there is a truth and insight in what people say, it turns out to be in unexpected ways." But all the examples of the Gyges-Cambyses story concern experiences or lessons of Boeke's second (social) category as I just argued and are of no relevance whatsoever to the proverbial strategies in the Solon passage.

${ }^{181}$ However, this does not mean that they may not be helpful in other respects. One might try out Seitel's 'three person' approach (above n. 175) on Solon's thirteenth elegy with its juxtaposition of two contradictory elaborations of 'proverbial' wisdom. Perhaps this may be seen as a corollary of Solon deploying a 'multi-addressee' strategy. There is a general consensus that he is addressing the (nouveau) rich (2nd person) of his time. But one may argue that in a self-reflective way he also addresses the '1st 


\section{The rehabilitation of parataxis}

Lardinois 2001, 93-107, has introduced a new and interesting element in the discussion in showing how standard proverbial themes are rarely passed on verbatim. Every generation or individual will cloth it in its own wording. "A set form is not a requirement for proverbial use" (Briggs). He notes that this is typical of an oral stage of text tradition. And with this we once more touch upon the other discovery going back to the early 20th century, that of the so-called paratactic style of archaic diction, which, however, as discussed earlier, was almost completely barred from the discourse of modern literary criticism. Here, too, the nineties witnessed the first signs of a revolutionary change. ${ }^{182}$ It appears that the notion of 'paratactic style' enjoys a glorious comeback thanks above all to the innovative work of E.J. Bakker, ${ }^{183}$ and S.R. Slings, ${ }^{184}$ who introduced the notion of 'speech' as opposed to 'text' as a major instrument for enquiry into the nature of archaic Greek discourse. Since not only Homer, but archaic poetry in general is oral, ${ }^{185}$

person' as well as a more general audience (3d person). Each might have been served with a selection of his proverbial arguments. Accumulating them into a paratactic composition reveals differences and effectuates contradiction (as well as a frightening proliferation of modern studies).

${ }_{182}$ As was recently brought to my notice by Caspar de Jonge and Marlein van Raalte.

${ }^{183}$ Bakker 1997; idem, The syntax of historiê: How Herodotus writes, in: Dewald \& Marincola 2006, 92-102.

184 S.R. Slings, Written and Spoken Language: An Exercise in the Pragmatics of the Greek Sentence, CP 87 (1992) 95-109; idem, Een tandje lager: Aanzetten voor een orale grammatica van Homerus, Lampas 27 (1994) 411-427; idem, Figures of Speech and their Lookalikes: Two Further Exercises in the Pragmatics of the Greek Sentence, in: E.J. Bakker (ed.), Grammar as Interpretation: Greek Literature in its Linguistic Context (Leiden 1997) 169-214; idem, Symposium: Speech and Ideology: Two Hermeneutical Issues in Early Greek Lyric, with Special Reference to Mimnermus (Med. Kon. Ak. Wet. 63 [2000] no. 1); idem, Oral Strategies in the Language of Herodotus, in: Bakker 2003, 53-77.

185 'Oral' is far from being an unequivocal notion, as inter alios illuminatingly argued by E.J. Bakker, Pointing at the Past: From Formula to Performance in Homeric Poetics (Hellenic Studies 12, Cambridge MA-London 2005), Ch. 3, "How Oral is Oral Composition?" (pp. 38-55). He differentiates between the two oppositions 'oral versus literate' and 'oral versus written', in the first of which 'oral' refers to the 'medium' of communication and in the second to a conception. This has serious consequences, including "that writing in the Greek archaic period must have been so different from our notion of writing, so 'oral', in fact, that the simple dichotomy between orality and literacy breaks down." When, in the following I will not make an appeal to the wellknown theories of Alexander Luria, Eric Havelock, Jack Goody and Walter Ong, claiming that the invention of writing (and reading) was the seminal impulse-and indeed conditional-to the early development of (our modern) formal rational thought and 
its way of expression should be situated within the wider contexts of spoken language and communication. It should be measured with the standards proper to 'speech' and no longer with the rules of written text. ${ }^{186}$

Now, spoken discourse can be seen as a sequence of short speech units reflecting the flow of speech through the consciousness of the speaker, as among others argued by Bakker 1997, in the first monograph on the subject. Chafe 1994, who is Bakker's source of inspiration especially in the latter's chapter 3, "Consciousness and Cognition," has coined them 'intonation units' emphasizing their physical, empirically observable quality as units of speech. ${ }^{187}$ Bakker 48, after Chafe 1994, 55:

The intonation unit is the linguistic equivalent of the focus of consciousness, the amount of information that is active at any one time in a speaker's consciousness. The intonation unit is the largest linguistic unit that is available in its entirety to consciousness, the typical sequence of speech sounds that is within the grasp of the speaker's, and listener's, echoic memory; any stretch of discourse that is longer will have to be processed as more than one of these basic chunks.

One might read this as an experiment-based theoretical commentary on the paratactic stringing of gnomic one-liners that we have found to be typical of archaic literature and Herodotus. Some years prior to

\footnotetext{
abstract conceptualisation, this is not because this theory should have been refuted by e.g. S. Scribner \& M. Cole, The Psychology of Literacy (Cambridge MA 1981 [not literacy itself but the educational process that leads to it would be the essential stimulus to logical conceptualisation, a theory massively disproved by the subsequent works of D. Olson, e.g. The World on Paper: The Conceptual and Cognitive Implications of Writing and Reading [Cambridge 1994]), nor for reasons of political or cultural correctness vis à vis the archaic Greeks, but simply because their orality belonged to Bakker's second category. These early Greek poets were not illiterate but created (most probably written) poetry that, however, was not intended for being recorded and stored in script (and read), but for memorization and oral performance. As such one might call it oral poetry made by a literate poet. See most recently: A. Lardinois, "Someone, I say, will remember us:" Oral Memory in Sappho's Poetry, in: E.A. Mackay (ed.), Orality, Literacy, Memory in the Ancient Geek and Roman World (Suppl. Mnemosyne 298, Leiden 2008), 79-96. For an informative critique of earlier theories and a nuanced position see: R. Thomas, Literacy and Orality in Ancient Greece (Cambridge 1992), also H. Yunis (ed.), Written Texts and the Rise of Literate Culture in Ancient Greece (Cambridge 2003).

${ }^{186}$ On the difference between spoken and written language: G. Brown \& G. Yule, Discourse Analysis (Cambridge 1983); Slings 1992 (see above n. 183).

187 S.R. Slings, Information Unit and Metrical Unit, in: I.L. Pfeijffer \& S.R. Slings (ed.), One Hundred Years of Bacchylides: Proceedings of a Colloquium Held at he Vrije Universiteit Amsterdam (Amsterdam 1999) 61-75, prefers the term 'information unit' but means the same.
} 
Bakker's book Slings had contributed the notion of 'pragmatics' to the discussion, arguing that in an oral grammar pragmatic requirements often overrule syntactic rules. Quite a few syntactical phenomena which, if judged according to rules of written texts, should be (and are being) disqualified as childish errors or primitive relics from archaic times, are unmasked and appreciated as normal and regular features of spoken language. This also and most specifically applies to what the scholars of the first half of the 20th c. (as well as, later, Milman Parry for Homer) called the adding or string style typified by paratactic organization. Both Bakker and Slings emphasize their prevalence in archaic literature but convincingly argue that this is not a heritage of a more primitive way of expressing (or worse: thinking). On the contrary, parataxis is a basic marker of speech, ancient or modern. We should discontinue associating it with the difference between archaic (primitive) and classic (polished) expression, and instead adopt a distinction between (spoken) 'speech' and (written) 'text'. It is the art of writing that gives an author time to string his speech-'chunks' into a hypotactical structure. Speech does not allow that. There it is "one chunk per clause." Although I think that one does not entirely rule out the other, the argumentation seems irrefutable.

Apart from providing revealing explanations of so far recalcitrant problems in early Greek discourse, (as well as justifying my earlier introduction-above p. 218-of the lexis eiromenê of a simple modern Greek native speaker by way of illustration of the diction of most hallowed ancient Greek authors!), the new approach gracefully rids us of the precarious notion 'primitive' connected with parataxis. And Herodotus? Was he 'oral'?

It is a platitude to say that Herodotus stands on the watershed between the oral and literate phases of Greek culture. Many idiosyncrasies of his style suggest that he stands in a tradition of telling stories, and that the written language in his time was only in its infancy. The challenge is to turn this impressionistic triviality into scholarship.

Thus the opening words of Slings's "Oral strategies in the language of Herodotus" (2002). He analyses Herodotus narrative fashion ${ }^{188}$ especially in his use of 'intonation/information units' of restricted length. Many of the gnomic wisdom expressions in the Solon-Croesus logos are of this nature. He finds typical Herodotean oral strategies such as

${ }^{188}$ As does Bakker (2006) in the field of syntax. 
chunking as we see it in the juxtaposition of information units. His conclusion:

Herodotus uses many oral strategies and he does so in a natural way because he has an audience of listeners in mind. Yet he uses also oral strategies where they are not required by the needs of the audience, in order to highlight important events in history. That is to say, although his is basically an oral style, he can also use oral as rhetorical devices when it suits him.

And it may well have been the latter motive that played a role in his paratactic organization of gnomic expressions in the Solon-Croesus logos.

\section{Thinking in gnomai-speaking in parataxis}

Two nearly obsolete discoveries of the early twentieth century have been revived, dusted off, and refreshed with a welcome facelift in modern theory. The application of 'speech' theory in particular has put the much abused lexis eiromene back on the agenda while considerably increasing our insight into its cultural ambience. I have retained my own disposition as it was written long before these newer refurbishments came to hit my retina, and have added the above review of them in the final phase of the book's completion. It is an immense relief to find that it is no longer anathema to label the phenomena that we discussed in this chapter: "thinking in gnomai-speaking in parataxis," and to take these as two characteristics of archaic and archaizing literature.

However, to some readers, as I found out, this may seem a dangerously banal result. And, on top of that, an irritating one since it lives on logical inconsistencies. Vicarious shame for such unsophisticated behaviour imputed to their author invites many a (professional) reader to either deride the mere suggestion of triviality or, if pressed further, as soon as possible to outsmart any touch of the banal or outmanoeuvre its inherent inconsistencies. The historian, on the other hand, has no other choice than to accept what he believes to have discovered. Sometimes life is fascinating, mostly it is banal. Then, for the scholar there is only one solution: let's make the banal fascinating. ${ }^{189}$

\footnotetext{
189 As it is propagated by for instance Natalie Zemon Davies especially in her 'Proverbial wisdom and popular errors', in: eadem, Society and Culture in Early Modern France. Eight Essays (Stanford 1975) 227-270, espec. 266: "Let us imagine just that we are watching our subjects with their differences in symbols, social intercourse, and
} 
But is it so trivial? One of the fascinating results of our quest is its bearing on the great debate between Dodds and Lloyd-Jones concerning the gradual change or continuity in the conceptions of divine justice as opposed to an a-moral fatalism, as it took its form in the Sather arena over the last fifty years. One may agree with Dodds that the differences are mainly a question of emphasis and focus, and "that both authors are right, though both at times exaggerating the partial truth they are stressing." But, what we have discovered is a pervasive co-existence of images of supernatural justice on the one hand, and various sorts of natural or supernatural arbitrariness and fatalism, on the other. If so, should we not consider the possibility that this persistent interaction of the two contrastive concepts is at least equally characteristic of the archaic Greek world view as either one of the two contesting views?

Living by maxims, - an encyclopedia of "as we say it"'s-in a luxuriant multiplicity, a never ending string of gnomai scattered over the total literary corpus, and sometimes, as exemplarily in our passages, ranged one after the other in a single context. While the Theognidean corpus represents a rather arbitrary collection of elaborated gnomai ${ }^{190}$ great authors have developed this geysering into an art 'good to live by'. Indeed, we may view the chains of sequences of gnomic wisdom in the passages of Homer, Herodotus and Solon as a skilful way of displaying the entire gamut of 'gnomologisches Wissen', without imposing a tyrannical coherence, allowing every reader to pick what he likes but not imposing any urge upon those readers or listeners that do not feel the need to choose.

So I would argue for a constant phenomenon, embodied in a simultaneous availability of expressions of hope and desperation, an optimistic and a pessimistic stance. As we all know, different Greek authors put their emphasis on different aspects, and every author would, in

technical apparatus. Let us imagine that they are in some sense equivalent to us, in some kind of exchange with us while we look them over, able to answer us back if we should go astray," a principle she applies herself by creating a discussion between subject and the author.

${ }^{190}$ Hence sometimes called the 'Gnomology' and taken as a collection brought together by different 'authors': J. Carrière, Théognis de Mégare. Étude sur le recueil élégiaque attribué à ce poète (Paris 1948). Cf. West 1974, 57. J.P. Brown, Proverb book, Gold economy, Alphabet, JBL 100 (1981) 169-191, traces back collections of proverbs like that of Theognis to Hebrew books of wisdom and concludes that commercial connections served as the way of transport. 
specific situations, opportunistically select that option which would best serve his goal. He opts for divine justice if he needs to warn off malicious opponents, and he chooses arbitrary fate if he is in need of an excuse for his own failure. The really interesting observation, however, is that there is not one consistent philosophy and that the two extremes so often appear in peaceful coexistence in one literary work or even in one passage. ${ }^{191}$ So they did in the Homeric passage that we took as our vignette and in the passages of Herodotus and Solon that we discussed. And as they most flagrantly do in Hesiod, that specialist in "multiple approaches," as he has been called, ${ }^{192}$ to whom we will now, finally, return.

\section{Putting to the Test: Hesiod}

The famous opening lines of Hesiod's Erga (1-10) consist of a hymn that glorifies Zeus:

1. Muses from Pieria, who glorify by songs,

2. come to me, tell of Zeus your father in your singing.

3. Because of him mortal men are unmentioned and mentioned,

4. spoken and unspoken of, according to great Zeus' will.

5. For easily he makes strong, and easily he oppresses the strong,

6. easily he diminishes the conspicuous, and magnifies the inconspicuous,

7. and easily he makes the crooked straight and withers the proud,

8. Zeus who thunders on high, who dwells in the highest mansions.

9. hearken as thou seest and hearest, and make judgment straight with righteousness,

10. Lord; while I should like to tell Perses words of truth.

191 And nothing to be ashamed of, for no less a person than Clifford Geertz has related this amphiboly with 'meaning'. Geertz 1966, 24: “The problem of meaning... is a matter of affirmation, or at least recognizing, the inescapability of ignorance, pain and injustice on the human plane while simultaneously denying that these irrationalities are characteristic of the world as a whole." For a discussion of this classic, see: T. Asad, Anthropological Conceptions of Religion: Reflections on Geertz, Man 18 (1983) 237-259.

192 Rowe 1983. His view of Hesiod's poetry finds an extreme counterpole in J. Strauss Clay, Hesiod's Cosmos (Cambridge 2003), who argues for a "coherent plan that unites the poems into a consistent vision that is both thoughtful and subtle" (p. 2). 
This is a true hymn in that it consists of two parts, of which one, comprising the first 7 or 8 lines, ${ }^{193}$ is an extended praise of the god that is invoked. The final two lines turn to a personal prayer for justice. ${ }^{194}$ In the commentaries one will find that, as a rule, the interpretation of the first part is coloured by the commentator's awareness of what is to come in the end, and, of course, by his/her familiarity with the central issue of the whole poem. Yet there is no reference whatsoever to this central theme in the first six lines. What we do have is a typical praise of omnipotence such as we find in abundance in hymnic poetry, especially emphasizing the god's power to do either of two opposite things 'easily', as we have seen in the first section of this chapter and will extensively discuss in the fifth chapter. ${ }^{195}$

In his commentary ad locum West rightly notes that "usually it is not represented as a question of what one deserves but simply as one of God's whim or private purposes," adding that up to line 7 "Hesiod does not go beyond this". He also points out that, still in the context of praise, line 7 introduces the suggestion that it is the unrighteous who are brought down. However this may be, the first lines picture Zeus as omnipotent, capable of arbitrarily interfering in two different directions, according to his free will. As such he comes very close to powers like Fate, or Fortune, or 'the Gods' or 'the Divine' to whom generally in archaic poetry the same principle of arbitrariness is assigned. There is no notion of morality involved. Only in the last lines does the objectivizing description change into a subjective prayer: Zeus' omnipotence now is exploited for a particular goal and, accordingly, is now positively specified as an instrument to do justice, naturally so, since it serves Hesiod's personal motive. But in Hesiod's works the two themes alternate alarmingly.

${ }^{193}$ Line 8 is a typical instance of 'dual functionality' as discussed above n. 67.

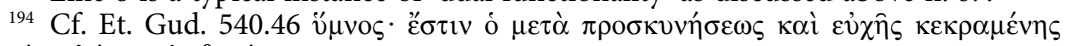

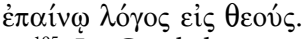

195 In Greek literature especially the element of 'making the small great and the great small' is popular in order to warn against feelings of superiority and 'haughty thoughts' (as we saw in Herodotus). After the Thebans have defeated the Spartans at Leuktra, Jason of Pherae warns them not to grow overconfident "for it seems that the

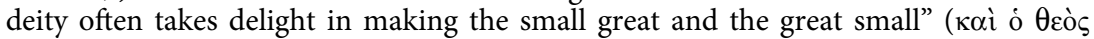

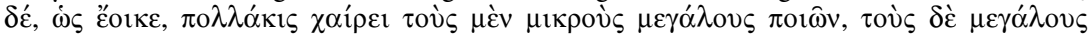
$\mu$ ккрои́ $)$ (Xen. Hell. 6.4.23). And see for its proverbial status below, Ch. V, p. 423, with n. 146. 
Now, it is the same Hesiod who in a few lines of his Theogony splendidly summarizes my argument. In Th. $901 \mathrm{ff}$., in a list of the marriages and offspring of Zeus: ${ }^{196}$

Second he (Zeus) married sleek Themis, who bore the 'Watchers'

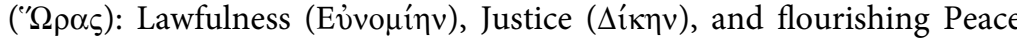

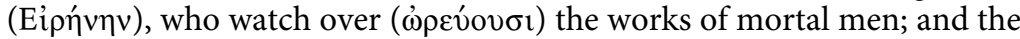
Fates (Moípas), to whom Zeus the resourceful gave the most privilege

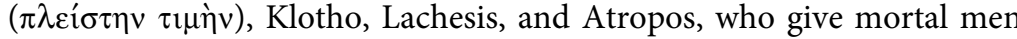
both good and ill.

We recognize the same two principles as implied in the opening hymn of the Erga, this time, however, staged as two triads of daughters of Zeus, the first three being the well-known personifications of Justice and her blessings ${ }^{197}$ the latter, the Moirai, as the explicitly arbitrary dispensers of good and evil. Fate(s) and Justice, each of them often pictured as close relatives of Zeus, either as daughter or as assistant or, in the case of the Moirai, also as superiors. ${ }^{198}$ Here, despite their

196 There is a different variation in the Great Eoiai $2=$ Anon. Comm. Ar. Nicom. Eth. 3.7. "And, they say, Hesiod is sufficient to prove that the word poneros (bad) has the same sense as 'laborious or ill-fated'; for in the Great Ehoiai he represents Alcmene as saying to Heracles: 'My son, truly Zeus your father begot you to be the

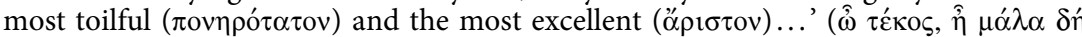

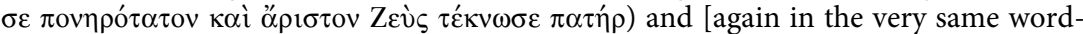
ing but with a different subject]: 'The Fates ( $\alpha$ i Moîp $\alpha$ ) (made) you the most toilful and the most excellent...'

${ }^{197}$ See: J. Rudhardt, Thémis et les Horai. Recherches sur les divinités grecques de la justice et de la paix (Genève 1999) 59-96, and Furley-Bremer 2001, I, 19-20. That the origin of the Horai may be connected with natural growth, fertility and lushness, "forces qui favorisent la croissance et la maturation des végétaux" (Rudhardt o.c. 15, as in Attika Auxo, Karpo, Thallo [Paus. 9.35.2]) and that this may have fostered the association with the moral and social qualities as represented in their names in this passage may all be true. See West a.l. But what is relevant here is the fact that these names in this passage cannot but directly refer to the moral domain of human life in connection and opposition to that of their sisters the Moirai. This in my view means

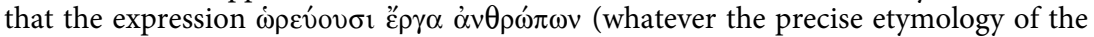
verb) cannot be understood here as "qui pour les hommes mortels protégent (gardent) leurs ouvrages." On the contrary, it is comparable with E. 253 f., where the "thirty thousand' gods are pictured as the "watchers of the immortals" who keep an eye on

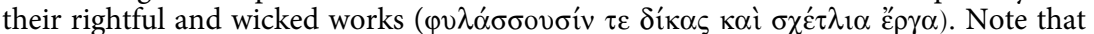

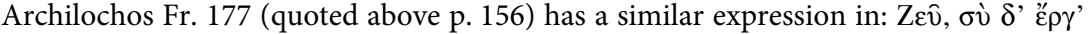

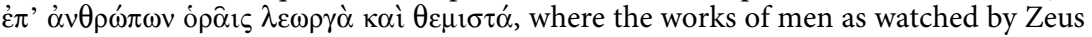
are explicitly taken in their moral implications.

198 As accounted for in our text by attributing to them "the most privilege." Elsewhere (Th. $217 \mathrm{ff}$.) Hesiod makes the Moirai the unfathered daugthers of Night. They may also take the position of the Horai: the Prayer to the Fates ascribed to Simonides (Bowra 1961, 404-415) asks the Moirai "who sit closest to Zeus" to send Eunomia, 
logical incompatibility, united as the daughters of Zeus and Themis, 'the divinely inspired order of things'. I could not have wished for a better illustration of what I have tried to argue.

\section{ENVOY}

It has been suggested that ${ }^{199}$ "Herodotus' narrative does perhaps more clearly convey the idea that the most fundamental of all human disabilities is the inability, displayed by Croesus, to understand the nature of human experience." I believe this is true. However, demonstrating this inability in such probing fashion as archaic Greek writers did, is to my mind anything but a disability. A great fascination and indeed a charm may be hidden in the agglutinative way in which Greeks expressed this inability, particularly in those fields which by definition can never be expected to yield decisive choices, solutions or conclusions, such as, pre-eminently, theology and philosophy of life. ${ }^{200}$ Here the Greeks might be lauded with the words of Charles Darwin: "There is grandeur in this view of life with its several powers." ${ }^{201}$ Accepting no bridle in their shifts of perspective, undogmatic in the elasticity of their representations, undaunted in accommodating the incompatible, desperate and hopeful, polytropic, so are my (early) Greeks.

Dike, and Eirene in succour to their city. For other links between Horai and Moirai, see: West $a d$ v. 904. Recently, G. Pironti, 'Dans l'entourage de Thémis: les Moires et les normes panthéoniques', in: Brulé 2009, 13-27, discusses the relationship of Themis and the Moirai as the representatives of two founding concepts of human and divine society: the norm and the partition. However, in the present passage, the Moirai are explicitly pictured in their more 'primitive' nature of arbitrary distributors of good and evil.

199 Gould 1989, 80.

200 This restriction is not superfluous. Even if we have seen that the stringing style also prevailed in early Greek scientific prose (above n. 165), we should beware of inconsiderately projecting conclusions that apply to the domain of theology onto other sections of human reflection with different types of discourse, social interaction or cultural embeddedness. This is the central theme of Lloyd 1990, who importantly concludes his research on early (formerly: 'primitive') cultures (p. 145): "But just as the analysis of individual utterances requires full account to be taken of the circumstances of delivery (...) so it may be argued more generally questions to do with systems of belief or modes of reasoning as a whole can only be answered if due attention is paid to types of social interaction and to the expectations participants may have concerning their nature and the manner of their conduct."

${ }^{201}$ In his conclusion of The Origin of Species on the pluriformity of the natural world, meant as an apologetic attempt to reconcile his theological opponents. 
In one of his vigorous attacks on our late-modern quest for unity and an emotional plea for pluralism, Paul Feyerabend 1986, that angry young man of post-modern thought, has hailed the "Aggregatcharakter der Homerischen Welt." In archaic Greek religion and culture in general, so he argues, there was an opportunistic eclecticism:

There is no insight which grasps a unity behind this plurality, no truth which - beyond individual facts-has a bearing on such a unity. There are insights and truths (plural), gained in different situations and in different ways and valid according to the laws that apply to these situations. Knowledge is the sum or the list of all insights gathered from all fields. ${ }^{202}$

I could not agree more. He may overstress his point a bit, but, then, don't we all? The early Greeks may have some interesting lessons for us. No solutions, but 'ways we say it'.

More than anywhere else in this book it is at this occasion that I wish to recall a phrase from the Introduction:

202 "Es gibt keine Erkenntniss, die eine Einheit hinter der Vielfalt erfasst, keine Wahrheit, die sich nicht nur auf individuelle Sachverhalte, sondern auf eine solche Einheit bezöge, aber es gibt Kenntnisse und Wahrheiten, in verschiedenen Situationen auf verschiedene Weise gewonnen und geltend nach dem für diese Situationen zuständigen Gesetze. Wissen ist die Summe, oder die Liste aller so gewonnenen Erkenntnisse aus allen Bereichen," adding (217): "In einer solchen Welt, die aus relativ selbständigen Teilen besteht, ist die Annahme universellen Gesetze nicht sachgemäss und die Forderung nach universellen Normen tyrannisch" (italics by the author. My translation differs from that of Farewell to Reason [London 2007] 98). It is striking how closely this resembles the words by Jolles 1930, $155 \mathrm{f}$. where he makes a differentiation between systematic philosophical truth and empirical-gnomic truth: "Wenn wir die Welt begreifen als eine Mannigfaltigkeit von Einzelwahrnehmungen und Einzelergebnissen, ergeben zwar diese Wahrnehmungen und Ergebnisse, reihenweise erfaßt und zusammengefaßt, jeweils die Erfahrung, aber auch die Summe dieser Erfahrungen bleibt eine Mannigfaltigkeit von Einzelheiten. (.....). Zwar gibt es auch hier ein Trennen und Verbinden (...) aber in den Bindungen überwiegt die Trennung, in den Bezogenheiten bleibt das Nebeneinander, in den Ordnungen die Sonderung der Glieder bestehen. Kurz, diese Welt ist nicht Kosmos, sie ist Sonderung, sie ist Empirie." Cf. another plea for such a type of pluralism in mythological context: O. Marquard, Lob des Polytheismus. Über Monomythie und Polymythie, in: H. Poser (ed.), Philosophie und Mythos. Ein Kolloquium (Berlin - New York 1979) 40-58, espec. 46: "Bekömmlich ist Polymythie, schädlich ist Monomythie. Wer polymythisch-durch Leben und Erzählen-an vielen Geschichten teilnimmt, hat durch die jeweils eine Geschichte Freiheit von der jeweils anderen (.....); wer monomythisch nur an einer einzigen Geschichte teilnehmen darf und muss, hat diese Freiheit nicht: er ist ganz und gar mit Haut und Haar von ihr besessen. Wegen dieses Zwangs zur restlosen Identität mit dieser Alleingeschichte verfällt er narrativer Atrophie. ...." 
I often have the impression that we exploit our classical texts as tools to show how clever we are in interpreting them, meanwhile imposing our strain towards coherence on their literary expressions, and thus paving our road towards the professorate (if not the Sather professorate). It would not be a bad idea at all if for once we would read their texts in what currently seems to be felt as a wayward manner, for example in order to see how they coped with questions that our paradigm still does not allow us to solve.

In contemporary Christian theology the division of theodicy is by far the most endangered of the whole concern, in fact it is close to bankruptcy and runs a fair risk of being closed down in the near future. ${ }^{203}$ How desperate the situation is can be learned for instance from an influential book on that subject written by one of the most distinguished specialists, Richard Swinburne. This modern apologete does regret all that human sorrow and suffering but extenuatingly argues for its utility in 'soul-making' in terms of its service to developing moral and religious virtues. And, to guild the pill, the Lord in his endless wisdom and love has put a limit to suffering, by decreeing that human life should not exceed 80 or 90 years: "Nobody can suffer more than 80 years." ${ }^{204}$ Quite some change, for that matter, after

${ }^{203}$ K. Surin, Theodicy? HThR 76 (1983) 225: "Despite the efforts of these and other theologians, the thought persists in many quarters that theodicy is perhaps one of the least satisfactory areas of the theological enterprise."

204 R. Swinburne, Providence and the Problem of Evil (Oxford 1998) 232: "God has ensured that there is a limit to the amount any human can suffer on Earth (...) The primary limit is provided by the safety barrier of death. God only (my italics) allows humans to suffer for periods of up to eighty years or thereabouts." And an extra stroke of luck: "Under too much pain we often become unconscious." Whoever is not satisfied with these two solutions of the problem may consult the showering of different answers to the problem of evil in a study of the greatest authority in the field: J.H. Hick, Evil and the God of Love (London $1977^{2}, 2007^{3}$ ), who, in his turn is an easy prey for his fellow theologians, whose own solutions, as for instance the so-called 'process theodicy', however, do not impress me as really more compelling. See e.g. D.R. Griffin, God, Power, and Evil: A Process Theodicy (Philadelphia 1976) and his frontal attack on Hick's theories in: St. T. Davis (ed.), From Encountering Evil: Live Options in Theodicy (Atlanta 1981). Cf. C.R. Mesle, John Hick's Theodicy: A Process Humanist Critique (London 1991). The problem is of course directly corollary to the belief in a god who is both almighty and good. Kennith Surin o.c. (preceding note) defines theodicy as the attempt to "reconcile the existence of an omnipotent, omniscient, and morally perfect God with the existence of evil" (on this crucial question see also below Ch. V p. $394 \mathrm{f}$., with nn. 42 and 46). This is most obvious in the world of the bible, as is revealingly elucidated in A. Laato \& J.C. de Moor (edd.), Theodicy in the World of the Bible (Leiden - Boston 2003), where the editors distinguish six categories of theodicy, each of which was activated whenever another did not seem to work: retributive theodicy; educative theodicy; eschatological theodicy; the mystery of theodicy; communion 
Martin Luther who liked to view God as wearing a mask and behind that mask playing with man as a cat plays with a mouse. In so doing he hurts man, admittedly, but, as Luther soothingly adds, "Er meint's nicht" ("He does not mean it"). Desperate and repellent explanations of grief and misery are moulded into conflicting dogmas as a result of our separative cosmology.

If then among the modern faithful with all their dogmas, credo, articles of faith, and catechism, there is no trace of uniformity concerning the problem of theodicy, why do we expect Greeks of the archaic and early classical periods to have had a clearer perception or a more consistent belief in the unfathomable ways of divine providence? I must admit that I have always found such assumptions as impertinent as they are incomprehensible. They tend to dehumanize my Greeks. As human beings Greeks were like you and me, exposed to the same uncertainties and doubts as any other human being that is confronted with the dazzling riddles of sudden inscrutable catastrophes. As Greeks, however, they were "others" and both the organization and the phrasing of their reactions is fundamentally different. Perhaps, for that very reason, we should try to learn from our Greeks instead of patronizing them.

theodicy; human determinism. The whole book is one never ending illustration of humans' desperate attempts to come to terms with the idea of the (in)justice of god in a monotheistic system. 